\title{
Evaluation of current and early production electronically controlled heavy-duty diesel engine emissions based on fuel property differences
}

\author{
Varakala Shashidhar Reddy \\ West Virginia University
}

Follow this and additional works at: https://researchrepository.wvu.edu/etd

\author{
Recommended Citation \\ Reddy, Varakala Shashidhar, "Evaluation of current and early production electronically controlled heavy- \\ duty diesel engine emissions based on fuel property differences" (2006). Graduate Theses, Dissertations, \\ and Problem Reports. 4260. \\ https://researchrepository.wvu.edu/etd/4260
}

This Thesis is protected by copyright and/or related rights. It has been brought to you by the The Research Repository @ WVU with permission from the rights-holder(s). You are free to use this Thesis in any way that is permitted by the copyright and related rights legislation that applies to your use. For other uses you must obtain permission from the rights-holder(s) directly, unless additional rights are indicated by a Creative Commons license in the record and/ or on the work itself. This Thesis has been accepted for inclusion in WVU Graduate Theses, Dissertations, and Problem Reports collection by an authorized administrator of The Research Repository @ WVU. For more information, please contact researchrepository@mail.wvu.edu. 
Evaluation of Current and Early Production Electronically Controlled

Heavy-Duty Diesel Engine Emissions Based on Fuel Property Differences

\author{
Varakala Shashidhar Reddy \\ Thesis submitted to
}

The College of Engineering and Mineral Resources at

West Virginia University

In partial fulfillment of the requirements

for the degree of

Master of Science

In

Mechanical Engineering

Advisory Committee Members

Gregory J. Thompson, Ph.D., Chair

Nigel N. Clark, Ph.D.

Mridul Gautam, Ph.D.

Department of Mechanical and Aerospace Engineering

West Virginia University

2006

Keywords: Diesel Engines, In-Use Emissions Testing, Fuel Properties, B20 


\section{ABSTRACT \\ Evaluation of Current and Early Production Electronically Controlled \\ Heavy-Duty Diesel Engine Emissions Based on Fuel Property Differences \\ Varakala Shashidhar Reddy}

Exhaust emissions emitted from heavy-duty diesel engines (HHDE) have been one of the contributors towards air pollution which indirectly have adverse effects on human health. This concern has made regulatory agencies impose stringent emissions standards in the United States and in many other countries. These increasingly stringent exhaust emissions levels have forced the HDDE manufacturers to focus largely on engine technology to reduce emissions levels to meet the regulatory standards.

Diesel fuel properties influence diesel engine emissions but how sensitive the engines are to theses property changes is the objective of this study. To examine the influences, regulated emissions from two engines were measured which represented early and current electronically controlled HDDE production. Commercially available on-road diesel fuels were tested along with a biodiesel blended fuel. A 1992 Detroit Diesel Corporation (DDC) Series 60 and a 2004 Cummins ISM370 engines were used to evaluate the diesel fuel property effects using engine dynamometer cycles like the US Transient cycle also know as the Federal Transient Procedure (FTP) cycle, the European Stationary Cycle (ESC) which is a 13 mode steady state cycle and two on-road cycles. Only engine-out emissions were examined. To determine which fuel property influences emissions it was necessary to decouple the intercorrelation between fuel properties. This decoupling was achieved by using Pearson correlation coefficients. Additionally, statistical analysis software was used to create models that predicted engine specific emissions based on the fuel properties which were not correlated.

Results show that NOx variation was as high as $16 \%$, HC of $40 \%, \mathrm{PM}$ of $44 \%$ and CO of $34 \%$ between fuels. However the levels of these variations were different for two the engines as the engines sensitivity to fuel property changes differed. 


\section{ACKNOWLEDGEMENTS}

I would like to take this opportunity to thank all the persons who helped me in completing this work. First I would like to thank my advisor, Dr. Gregory Thompson, for providing me an opportunity to work with him and helping me learn about engine emissions testing. Dr. Thompson not only helped me in learning things at the lab but also helped in over coming initial hurdles of my Masters at WVU with his guidance and advices. I also thank Dr Mridul Gautam and Dr Nigel Clark, for being in my committee and providing information which helped me in completing my masters.

I also would like to extend my acknowledgement towards Dan Carder and Tom Spencer for helping me through the difficult times in the testing phase of my thesis work. Dan and Tom, thanks once again for helping me when I needed it the most. Without Mahesh and Karthik, I wouldn't be able to get through the long hours and wouldn't have completed my thesis testing within in time. Also I would like to thank Byron Rapp for all his help (especially helping me fix my car and for the lovely thanks giving lunch) during testing and the good times in EERL. I also thank my friends for providing good company during my stay in WVU. Amar, thank you for good food and you're the best roommate ever. Above all, the help you extended me all times from beginning of my days in WVU.

Last but not the least important people in my life, are my thanks to my parents, who supported me throughout my life and provided a comfortable life. Sridhar and Sravanthi, thank you for your encouragement at all times and also for accompanying me through good and bad times of my life. 


\section{TABLE OF CONTENTS}

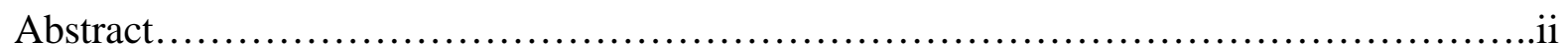

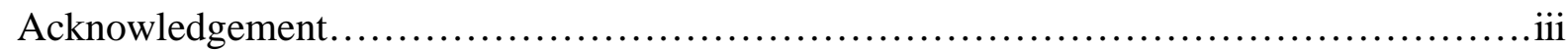

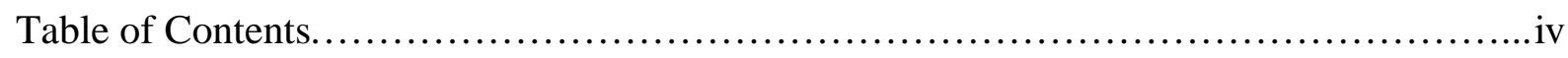

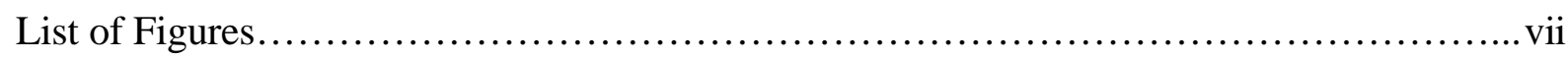

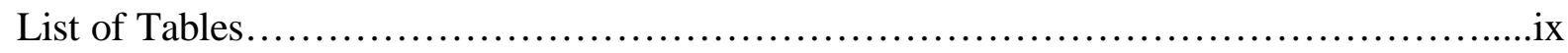

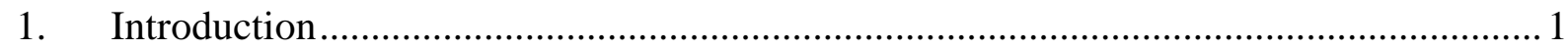

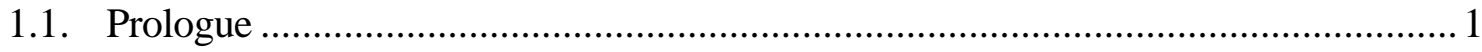

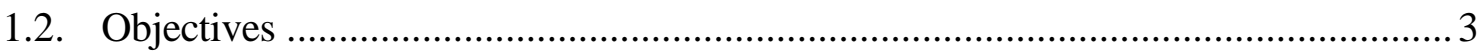

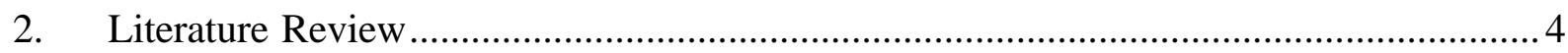

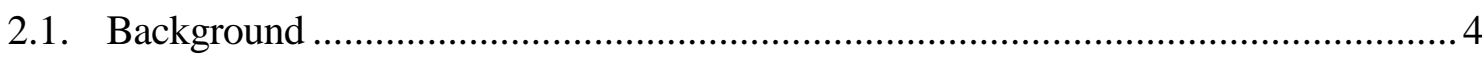

2.2. Previous Studies on Effect of Fuel Properties on Engine Emissions ....................... 6

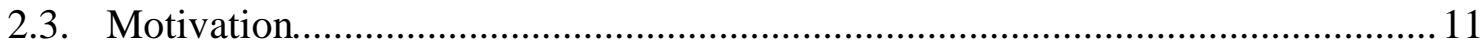

3. Experimental Equipment and Procedures ………..................................................... 12

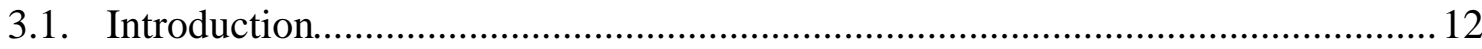

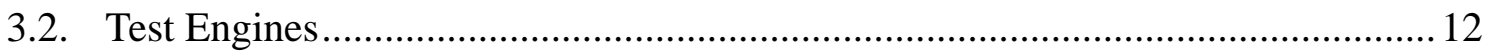

3.2.1. Detroit Diesel Series 60 ..................................................................... 12

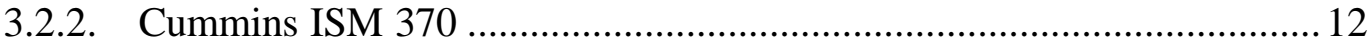

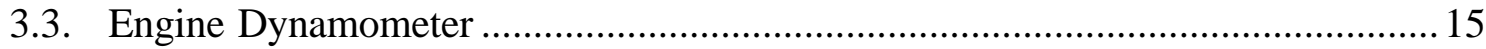

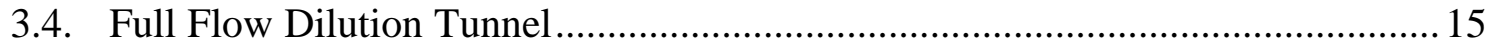

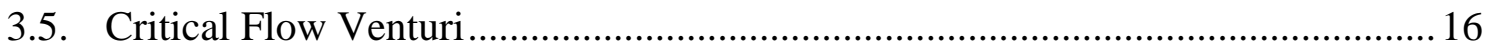

3.6. Gaseous Emission Sampling System............................................................ 16

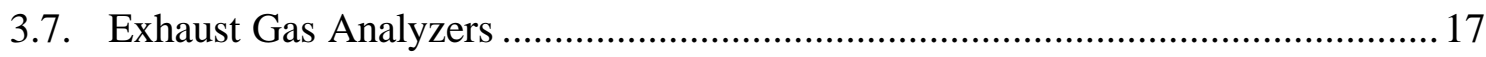

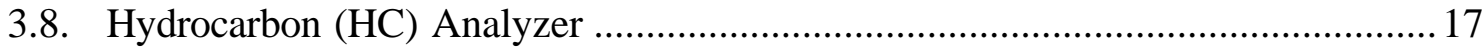

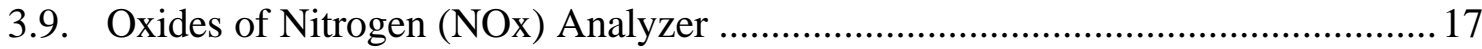

3.10. Carbon Monoxide (CO) and Carbon Dioxide (CO2) Analyzer.............................. 18

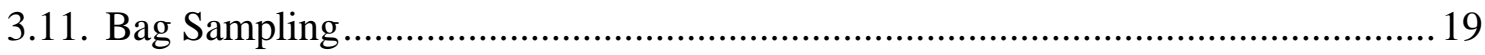

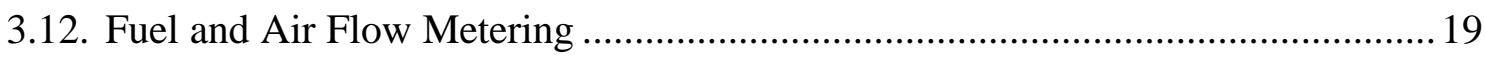

3.13. Instrumentation Control and Data Acquisition..................................................... 19

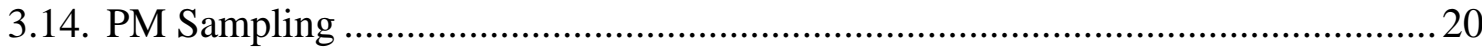

3.15. Tapered Element Oscillating Microbalance (TEOM) ……………………............ 21

3.16. Quality Control and Quality Assurance Procedures ..............................................22 


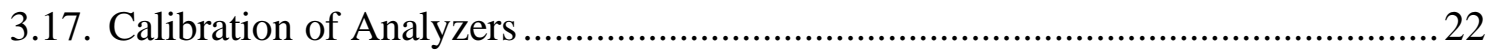

3.18. Propane Injections ……………………………........................................ 23

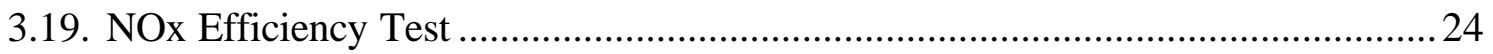

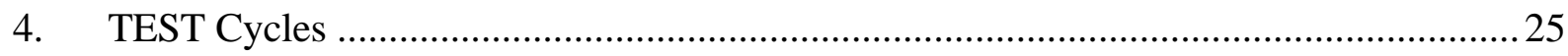

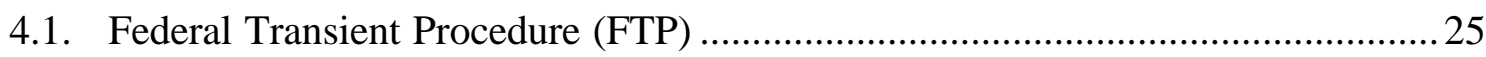

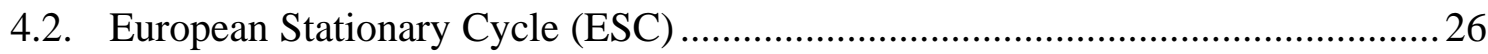

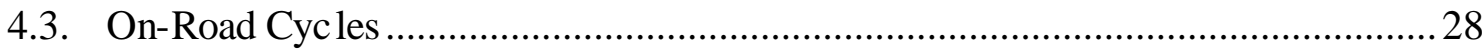

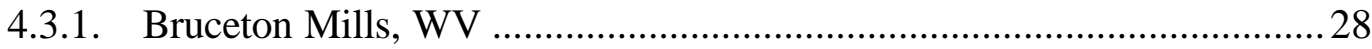

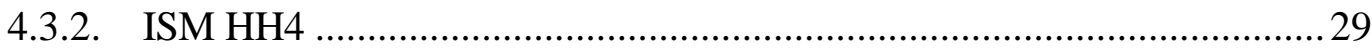

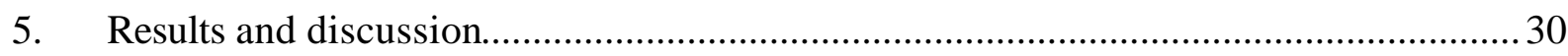

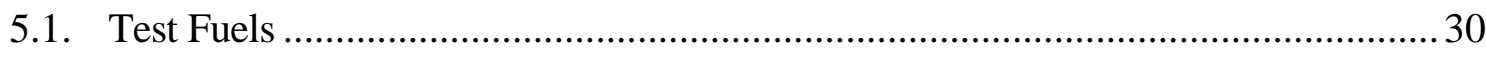

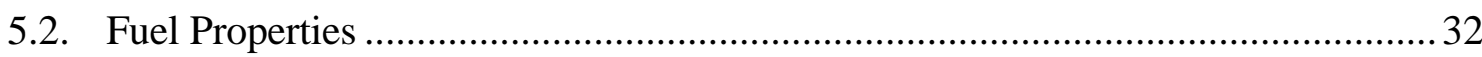

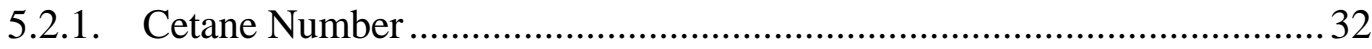

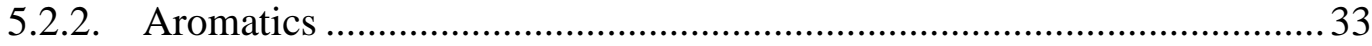

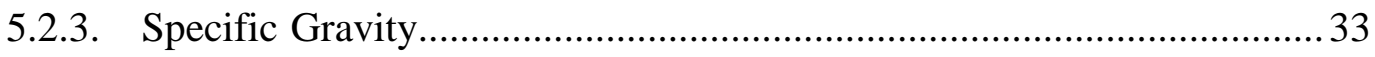

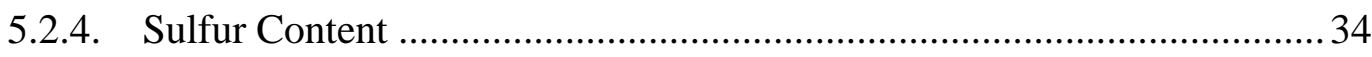

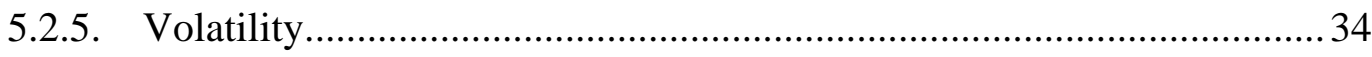

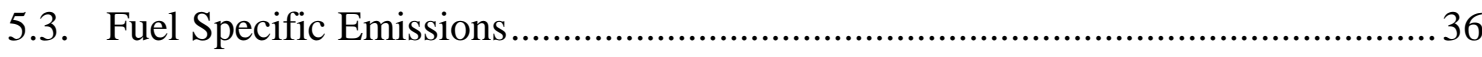

5.3.1. Fuel Specific HC emissions ................................................................. 40

5.3.2. Fuel Specific NOx Emissions ............................................................... 41

5.3.3. Fuel Specific PM Emissions ............................................................... 42

5.3.4. Fuel Specific CO and CO2 Emissions ................................................... 43

5.3.5. Work and Fuel Economy ......................................................................... 43

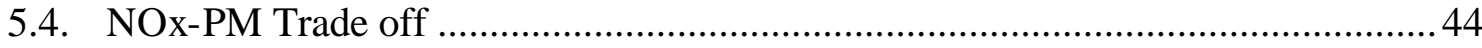

5.5. Influence of Fuel Properties on Emissions ………………………........................ 45

5.5.1. Effect of Cetane Number ........................................................................ 45

5.5.2. Effect of Density on Emissions .............................................................. 47

5.5.3. Effect of Sulfur on Emissions .................................................................. 48

5.5.4. Effect of Total Aromatics on Emissions ................................................ 50

5.5.5. Effect of Specific Gravity on Energy Content ......................................... 52

5.5.6. Effect of Volatility on Emissions ............................................................ 53

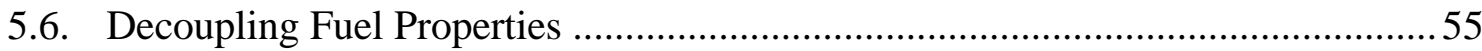


5.7. Prediction of Emissions from Mathematical Models .........................................57

5.8. Influence of Fuel Properties on Steady State Modes in ESC .............................59

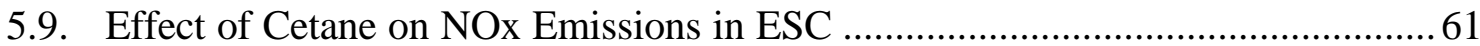

5.10. Comparison between Conventional and Biodiesel blend ................................. 61

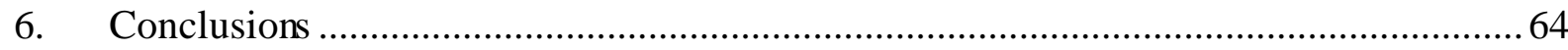

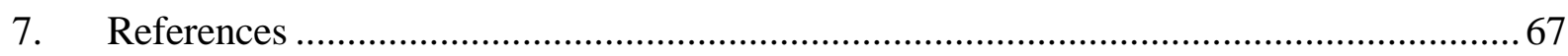

Appendix A.................................................................. 71

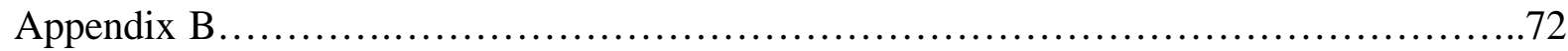

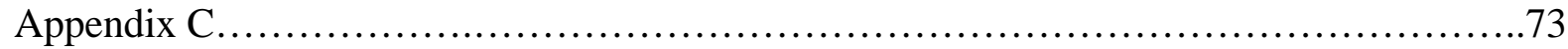

Appendix D.............................................................. 74

Appendix E............................................................... 80

Appendix F................................................................ 81 


\section{LIST OF FIGURES}

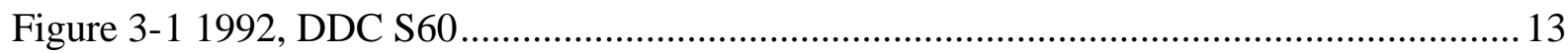

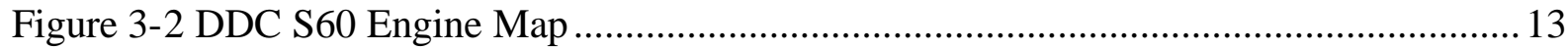

Figure 3-3 Cummins ISM 370 connected to the GE Engine Dynamometer ............................ 14

Figure 3-4 Cummins ISM 370 Engine Map ...................................................................... 14

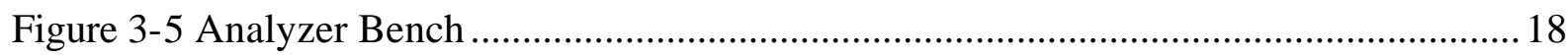

Figure 3-6 Data Acquisition and PM Sampling ………….................................................... 20

Figure 3-7 Mettler Toledo UMX2 Microbalance ............................................................... 21

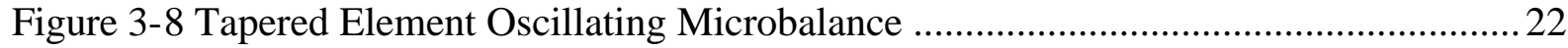

Figure 4-1 Engine Speed versus Time for the FTP Cycle ....................................................... 26

Figure 4-2 Engine Torque versus Time for the FTP cycle .................................................... 26

Figure 4-3 Example ESC Set Points and Weighting Factors ..................................................2 27

Figure 4-4 Engine Speed and Torque Versus Time for the SAB2BM Route Cycle .................2 28

Figure 4-5 Engine Speed and Torque Versus Time for the ISM HH4 Route Cycle .................2 29

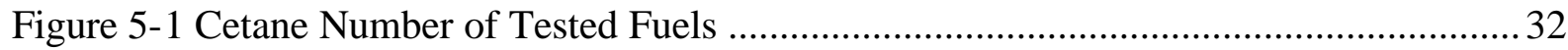

Figure 5-2 Aromatic Contents of Tested Fuels ..................................................................... 33

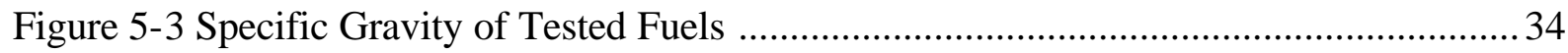

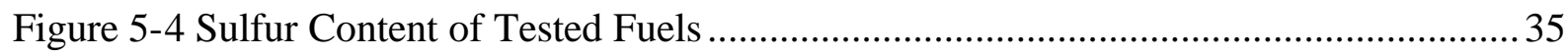

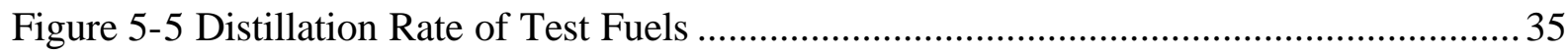

Figure 5-6 Fuel Specific HC Emissions for FTP and ESC Cycles ...........................................4 40

Figure 5-7 Fuel Specific $\mathrm{NO}_{\mathrm{x}}$ Emissions for FTP and ESC Cycles .......................................... 41

Figure 5-8 Fuel Specific PM Emissions for FTP and ESC Cycles ...........................................42

Figure 5-9 Fuel Specific Work Done and BSFC over FTP ................................................... 44

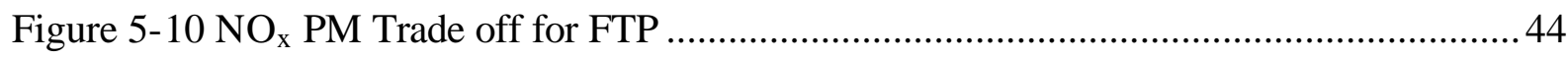

Figure 5-11 Effect of Cetane on DDC S60 over FTP ......................................................... 46

Figure 5-12 Effect of Cetane on Cummins ISM over FTP ....................................................4 46

Figure 5-13 Effect of Specific gravity on DDC S60 over FTP .............................................. 47

Figure 5-14 Effect of Specific gravity on Cummins ISM over FTP ........................................ 48

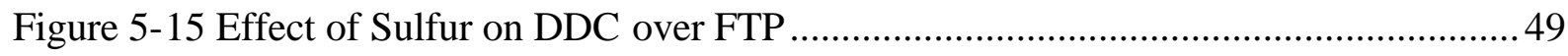

Figure 5-16 Effect of Sulfur on Cummins ISM over FTP ................................................... 49

Figure 5-17 Effects of Total Aromatics on DDC S60 over FTP ............................................ 51

Figure 5-18 Effects of Total Aromatics on Cummins ISM over FTP .....................................51 
Figure 5-19 Effects of Polya romatics on DDC S60 over FTP ........................................... 51

Figure 5-20 Effects of Polyaromatics on Cummins ISM over FTP ....................................51

Figure 5-21 Effect of Specific Gravity on Energy Content............................52

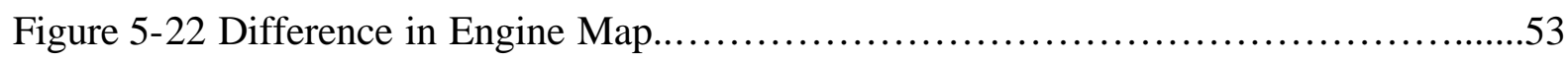

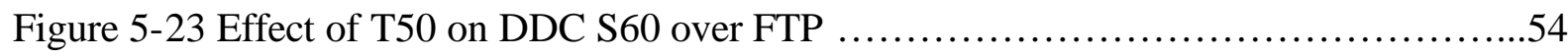

Figure 5-24 Effect of T50 on Cummins ISM 370 over FTP ........................54

Figure 5-25 Effect of T95 on DDC S60 over FTP ...................................54

Figure 5-26 Effect of T95 on Cummins ISM 370 over FTP ............................54

Figure 5-27 Comparison of $\mathrm{NO}_{\mathrm{x}}$ Emissions Over the 13 Mode ESC for the Two Engines..... 60

Figure 5-28 $\mathrm{NO}_{\mathrm{x}}$ Emissions of 8 mode and 13 mode of ESC ........................................... 60

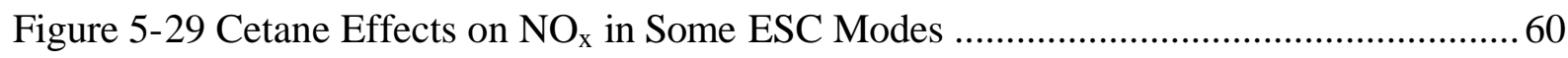

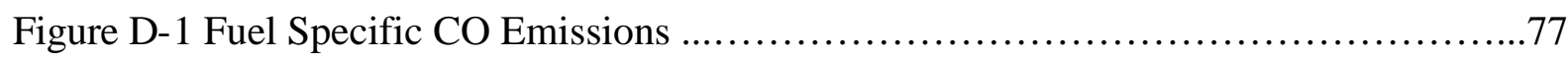

Figure D-2 Fuel Specific $\mathrm{CO}_{2}$ Emissions....................................... 77 


\section{LIST OF TABLES}

Table 1-1 EPA and CARB Emission Standards for Heavy-Duty Diesel Engines .................... 1

Table 1-2 Emission Standards for 2004 and 2007 and Later .............................................. 1

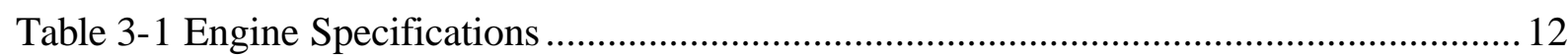

Table 3-2 Calibration Gases Used for Testing ............................................................... 23

Table 4-1 Example Set Points for 13-Mode ESC .............................................................. 27

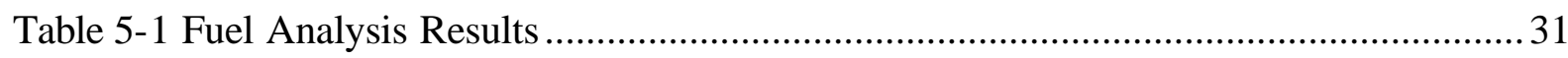

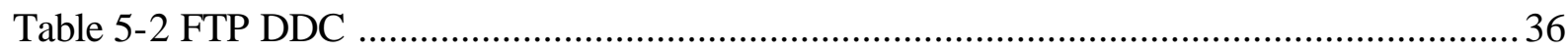

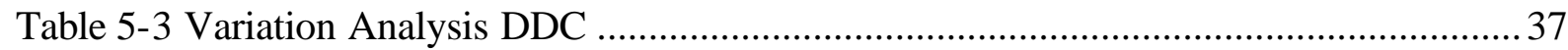

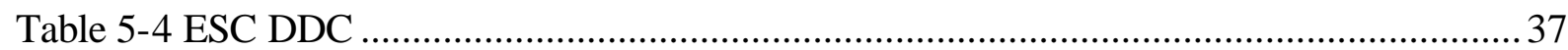

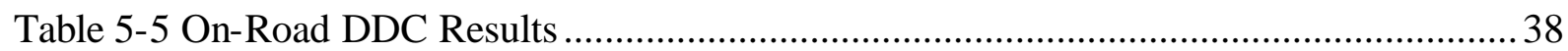

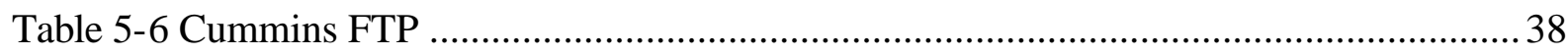

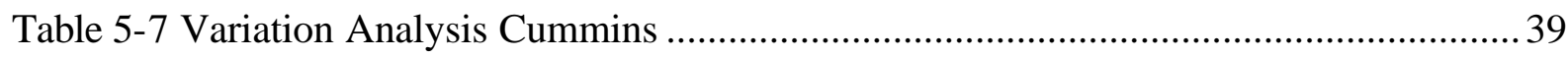

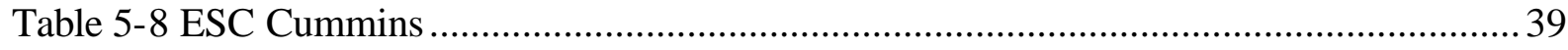

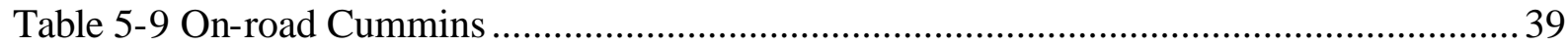

Table 5-10 Pearson Correlation Coefficient ....................................................................... 56

Table 5-11Combination of Fuel Properties ...................................................................... 57

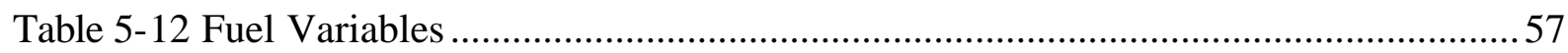

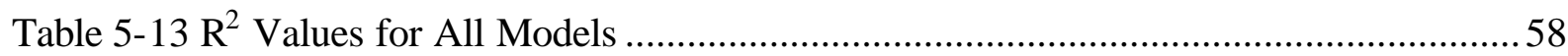

Table 5-14 Comparison between Measured and Predicted Emissions for Cummins ............. 58

Table 5-15 Comparison between Mesured and Predicted Emissions for DDC ......................59

Table 5-16 Comparison between conventional and Biodiesel over FTP .............................62 62

Table 5-17 Comparison between Conventional and Biodiesel over ESC ............................ 63

Table 6-1 Correlation Coefficients between Fuel Properties and NOx.................................. 64

Table 6-2 Correlation Coefficients between Fuel Properties and PM.................................. 65

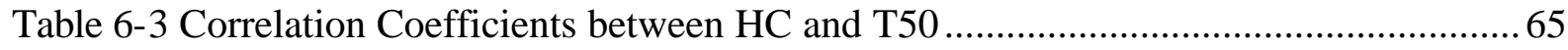




\section{INTRODUCTION}

\subsection{Prologue}

Concern over the contributions of the exhaust emissions from HDDE on air quality has made the U.S. Environmental Protection Agency (EPA) and the California Air Resource Board (CARB) set stringent emissions levels. The regulated diesel emissions which are of major concern are the oxides of nitrogen $\left(\mathrm{NO}_{\mathrm{x}}\right)$, which consists of nitric oxide (NO) and nitrogen dioxide $\left(\mathrm{NO}_{2}\right)$, particulate matter $(\mathrm{PM})$, hydrocarbons $(\mathrm{HC})$, carbon monoxide $(\mathrm{CO})$ and nonmethane hydrocarbons (NMHC). Emission standards according to the EPA and CARB from model year 1988 to 1998 are shown in Table 1-1 and model year 2004 and 2007 and later are shown in Table 1-2 for heavy-duty diesel trucks tested over the Transient Federal Testing Procedure (FTP) engine dynamometer cycle, with emissions defined in grams per brakehorsepower hour (g/bhp-hr) [1]. The 2007 and later standard has imposed regulations on diesel fuel limiting the sulfur content in on-highway diesel fuel from 500 to $15 \mathrm{ppm}$.

Table 1-1 EPA and CARB Emission Standards for Heavy-Duty Diesel Engines

\begin{tabular}{|c|c|c|c|c|c|c|}
\hline Standards & Year & $\mathrm{HC}$ & $\mathrm{CO}$ & $\mathrm{NO}_{\mathrm{x}}$ & $\mathrm{PM}$ & NMHC \\
\hline \multirow{5}{*}{ EPA } & 1988 & 1.3 & 15.5 & 10.7 & 0.60 & - \\
\cline { 2 - 7 } & 1990 & 1.3 & 15.5 & 6.0 & 0.60 & - \\
\cline { 2 - 7 } & 1991 & 1.3 & 15.5 & 5.0 & 0.25 & 1.2 \\
\cline { 2 - 7 } & 1994 & 1.3 & 15.5 & 5.0 & 0.10 & 1.2 \\
\hline \multirow{3}{*}{ CARB } & 1998 & 1.3 & 15.5 & 4.0 & 0.10 & 1.2 \\
\cline { 2 - 7 } & 1987 & 1.3 & 15.5 & 6.0 & 0.6 & - \\
\cline { 2 - 7 } & 1991 & 1.3 & 15.5 & 5.0 & 0.25 & 1.2 \\
\hline
\end{tabular}

Table 1-2 Emission Standards for 2004 and 2007 and Later

\begin{tabular}{|c|c|c|c|c|c|}
\hline \multirow{2}{*}{ Year } & Option & NMHC $+\mathrm{NO}_{\mathrm{x}}$ & $\mathrm{NMHC}$ & $\mathrm{CO}$ & $\mathrm{PM}$ \\
\hline \multirow{2}{*}{$2004^{*}$} & 1 & 2.4 & $\mathrm{n} / \mathrm{a}$ & 15.5 & 0.1 \\
\cline { 2 - 6 } & 2 & 2.5 & 0.5 & 15.5 & 0.1 \\
\hline \multirow{2}{*}{2007} & $\mathrm{NO}_{\mathrm{x}}$ & $\mathrm{NMHC}$ & $\mathrm{CO}$ & $\mathrm{PM}$ \\
\cline { 2 - 6 } & 0.2 & 0.14 & 15.5 & 0.01 \\
\hline
\end{tabular}


Over the past decade, with improving technology in the heavy-duty diesel engines, significant reductions in emissions have been achieved. However, application of technology would result in an improvement in either $\mathrm{NO}_{\mathrm{x}}$ or particulate matter emissions and decrease in the other (NOx PM trade off) along with an effect on fuel consumption. Although engine designs have a greater affect on the emissions than fuel quality, fuel does affect the emissions generated.

The implementation of in-use testing came into existence due to a court settlement reached between the EPA, US Department of Justice, CARB and the settling engine manufacturers (Caterpillar, Cummins, Detroit Diesel, Volvo, Mack and Navistar) over the issue of high $\mathrm{NO}_{\mathrm{x}}$ emissions due to the control strategies employed by the engine manufacturers during cruising on highways [2]. The engine manufacturers used engine control software to control the fuel consumption so as to be more fuel efficient during which higher NOx was produced.

West Virginia University (WVU) has assisted the settling engine manufacturers meet requirements of the Consent Decrees. A Mobile Emissions Measurement System (MEMS) was developed by WVU which was evaluated and procedures were developed for heavy-duty diesel-powered vehicle emissions which was later used to measure on-board emissions [2, 3, 4].

Prior to the in-use emissions testing requirements from the Consent Decrees, engine manufacturers were not concerned with fuel properties. Engine certification has always been performed with a fuel specified in the regulations. Now, manufacturers are required to do inuse testing and account for variability in fuels. A study by Gibble was motivated by the Consent Decrees, examined the effects of fuel properties on an engine which was tested onroad and later compared with the results obtained from the engine run by engine dynamometer 5]. The engine used for that study was a 1999 Ford B250 (International T444E). It was found that the commercially available on-road fuels had variations in the emissions emitted from the engine. But the question lies in whether it is the fuel properties or the engine technology that plays a vital role. This formed the motive for this research which studies the effect of fuel properties between older technology engines and a newer technology engine using six commercially available on-road diesel fuels. 
A number of studies have identified important diesel fuel properties (cetane number, specific gravity, aromatics, sulfur and volatility) which influence the engine emissions. One of the difficulties faced by prior studies was that the fuel properties tend to be intercorrelated which poses a problem to identify a specific fuel property that directly influences emissions.

\subsection{Objectives}

The main objective of this study was to evaluate engine emissions from the commercially available diesel on early and current electronically controlled production HDDE. The engines were tested on dynamometer cycles like the FTP, ESC and an on-road cycles. The study looked into the aspect whether fuel properties have a considerable effect on low emission production engines or whether it's the technology which was the dominant factor for reduction in emissions.

The second objective was relating the effects of fuel properties on engine emissions. To examine that, it was pertinent to decouple the intercorrelation of fuel properties, which was achieved by using Pearson correlation method. Additionally, statistical analysis software was used to create models that predicted emissions which were engine specific based on the fuel properties which were not correlated.

The third objective was to test the advantages of using biodiesel blend with diesel fuel. A B20 blend was chosen for this study which consisted of $80 \%$ diesel fuel and remaining $20 \%$ of biodiesel which was tested on both engines to evaluate the influence of its properties on engine emissions. 


\section{LITERATURE REVIEW}

\subsection{Background}

Diesel fuels composition mainly consists of hydrocarbons and to a lesser degree, organic compounds like sulfur, nitrogen and oxygen. Diesel fuels are influenced by crude source and method of refining. They are obtained from petroleum having a wide boiling range from $150-380^{\circ} \mathrm{C}$. The hydrocarbons which are the major constituents are classified into three categories namely the normal paraffins which are straight-chain compounds $\left(\mathrm{C}_{n} \mathrm{H}_{2 n+2}\right)$, then the aromatic hydrocarbons and cycloparaffins also called as napthenes $\left(\mathrm{C}_{\mathrm{n}} \mathrm{H}_{2 \mathrm{n}}\right)$ [6].

What makes one diesel fuel different from another is the proportion of paraffins, napthenes and aromatic hydrocarbons. Paraffins are associated with lowest specific gravity and highest cetane numbers where as aromatics have higher specific gravity and boiling points but lower on cetane than the paraffins. Napathenes on the other end have the highest specific gravity and boiling point and lowest cetane number.

Diesel fuel property qualities are specified by the standards in the respective countries like the ASTM D975 in the USA, EN 590 in the European Union and JIS K2204 in Japan and some of fuel properties are specific to the emissions regulations [7]. Most of the diesel fuels properties which are important are subjected to stand ards by which they are measured. The important properties which influenced combustion include cetane number, specific gravity, volatility and viscosity.

Normally fuel properties can be divided into two categories namely physical and chemical properties. Physical properties are measured using standard measurement methods to determine its property where as for the chemical property they are measured through interaction of a fuel with a standardized measurement apparatus. Some of the examples that fall under physical properties are the specific gravity, sulfur content, viscosity and volatility and examples for chemical properties are cetane number, flash point and lubricity. 
The important diesel fuel properties that have an influence on emissions from heavyduty diesel engines are as follows

$\circ$ Cetane Number
$\circ$ Specific Gravity
$\circ$ Sulfur Content
$\circ$ Volatility
$\circ$ Aromatics

Cetane number is the measure of ease with which a fuel ignites when injected which influences ignition delay. High cetane number fuels are characterized by short ignition delay where as for low cetane number it is the converse. The ASTM D613 method is used to calculate the cetane number [7]. The cetane number of fuel is determined by comparing its ignition quality under standard operating conditions with two reference fuel (n-hexadecane or normal cetane and having a cetane number of 100 and a heptamethyl nona ne having a cetane number of 15) using a Cooperative Fuel Research (CFR) single cylinder engine. The formula used to calculate is given below

Cetane Number $=\%$ n-cetane $+0.15(\%$ heptamethyl nonane $) \quad$ Equation $(1)$

Specific gravity (relative density or RD) is the ratio of density of material to density of water which is measured using the ASTM 287 method [7]. In the USA, a common measure for density is expressed in degrees of API gravity which has an inverse relation with specific gravity, an arbitrary scale developed by the American Petroleum Institute. API gravity is measure using the ASTM 1298 method and calculated by the formula given below

${ }^{\circ} \mathrm{API}$ gravity $=(141.5 / \mathrm{RD})-131.5 \quad$ Equation $(2)$

Sulfur is one of the contributors towards PM where sulfur trioxide $\left(\mathrm{SO}_{3}\right)$ binding with water forms sulfuric acid and sulfur dioxide $\left(\mathrm{SO}_{2}\right)$ emissions formed during combustion inside the engine. The resulting sulfur compounds have a negative environmental impact. In the early 1990's, sulfur level was restricted to $5000 \mathrm{ppm}$ and later on environmental regulations further limited the sulfur content to $500 \mathrm{ppm}$ and was termed low sulfur diesel. For the 2007 and later emissions standards the sulfur is reduced from 500 ppm to 15 ppm (termed ultra low sulfur diesel fuel). Effects of sulfur on engine emissions has been discussed 
in many studies made on effect of fuel properties on engine emissions discussed later in this section. The ASTM D2622 or D5453 method is used to calculate the sulfur content [7].

Volatility of diesel fuel relates to the temperatures at which successive portions are distilled and then collected using standardized apparatus under controlled temperature which is measured by the ASTM D86 method [7]. In this method the fuel sample is placed in distilled apparatus and heated till the vapors are formed due to increase in temperatures which are later condensed and collected in cylinder marked with percentage of initial volume of liquid. The distillation temperatures of interest are the T50, T90 and T95.

Aromatics are normally referred to as total aromatics and are one of the important fuel properties on which many studies have been made to study the effect of it on engine emissions. The problems encountered during the studies were trying to decouple the intercorrelation between other properties which together influence the engine emissions. The ASTM D5186 method is used to measure the aromatic content [7].

Viscosity is defined as the resistance to flow, higher the viscosity greater is the resistance to flow and also decreases with increases in temperature. Viscosity is significant property which influences the atomization of fuel and lubricity of fuel [8]. Kinematic viscosity is defined as the ratio of dynamic viscosity to density of fuel. The ASTM standard used to measure is ASTM D445 [7].

Flash point of a fuel is defined as the temperature at which vapors from a combustible liquid ignite when exposed to a flame over the surface of the liquid. This is measured using the ASTM D93 method. Flash point is significant property to be measured which is important while handling and storing of fuels. A minimum flash point temperature is set by the standards, which is set to $38^{\circ} \mathrm{C}$ and any fuel below it indicates hazardous.

\subsection{Previous Studies on Effect of Fuel Properties on Engine Emissions}

The requirement to identify the significant fuel properties that have an affect on engine emissions has initiated many studies in this direction. Technologies incorporated by the engine manufacturers were the solution for reduction in emissions over the last 15 years. With the Consent Decrees and the requirement to perform in-use emissions testing, fuel 
properties and fuel quality play a significant role in low emissions engines. The following studies discussed about significant fuel properties that influence the engine emissions.

A study by Cummins Engine Co. and Shell Oil Co. investigated the effect of diesel fuel properties in 1974 [6]. The study concluded that cetane number was the most significant diesel fuel property that had an effect on diesel emissions. The results showed that low cetane fuels resulted in higher hydrocarbons and oxides of nitrogen and conversely higher cetane fuels showed lower emissions. The fuels were tested on a 13-mode test with specially blended fuels to provide wide range in cetane number, specific gravity, aromatic content and volatility but were not commercially sold. Three production engines along with a prototype low emissions engines which was designed to meet $5 \mathrm{~g} / \mathrm{bhp}-\mathrm{hr}\left(\mathrm{NO}_{\mathrm{x}}+\mathrm{HC}\right)$ were used for testing. Also, the study showed that the fuel properties alone do not provide a solution for major reduction in emissions it's the engine design that plays a vital role. Nevertheless it was recognized that with engine modifications for lower emissions the engines may become sensitive to fuel properties.

In 1979 a study was performed to examine the effects of fuel specific gravity, volatility, aromatics and sulfur content on particulates [9]. The test were performed using a naturally-aspirated, direct-injection diesel engine. The study concluded that with high aromatic and distillation temperature and low specific gravity the total mass of particulate matter was high.

Navistar completed a study in 1988 relating the effects of sulfur content on diesel emissions [10]. The study found similar trends for direct and indirect injection engines, with and without turbocharger apparatus. The sulfur content was varied from 0.05 to $0.29 \%$ by weight, and an increase in sulfur content increased the brake-specific PM emission from 0.06 to $0.07 \mathrm{~g} / \mathrm{bhp}-\mathrm{hr}$. Increases in fuel sulfur content also increased the percent sulfate in TPM.

Southwest Research Institute conducted a study to investigate the effects of fuel composition on heavy duty diesel engine emissions in 1989 [11]. This was sponsored by the Coordinating Research Council to yield quantitative emissions data and emissions model to relate diesel fuel properties to emissions from modern heavy-duty diesel engines. The test were conducted over the EPA transient cycle using fuels in which three primary fuel properties, namely aromatics, volatility and sulfur were varied. The test fuels were not 
commercially sold diesel fuels. One of the engines used for this study was a 14-liter Cummins Engine Co. NTCC 400 which met the 1988 CARB standards. The second one was an 11-liter DDC S60 and the third was a 7.3-liter Navistar International Corp. which was designed to meet the 1991 emissions standards.

The results were used to model transient composite emissions which were engine specific through multiple linear regression method. To decouple the intercorrelation of fuel properties, Pearson correlation coefficient analysis was used. A correlation coefficient greater than 0.90 , implied a good correlation between the two properties. Along with this, emissions were also correlated with fuel properties so as to see any direct effect of fuel properties on emissions. The aromatic content had a significant effect on $\mathrm{HC}, \mathrm{CO}, \mathrm{NO}_{\mathrm{x}}$ and particulate matter for all three engines. Volatility represented by T90 was significant for all emissions except on particulate matter for the DDC S60. Sulfur made a significant effect on particulate matter for all engines and on HC emissions except for NTCC 400 and in the case of $\mathrm{NO}_{\mathrm{x}}$ and CO emissions it had no effect.

Shell Research Ltd. and Thornton Research Centre studied the effect of fuel properties on particulates emissions in heavy-duty truck engines under transient operating conditions in 1991 [12]. The study concluded that sulfur content and fuel density had an effect on particulates emissions in the U.S. transient tests. The engine used for the testing was a preproduction 12-litre DDC S60 designed to meet the 1991 US emissions standards. The results showed that increasing sulfur content and fuel density increased the total particulate mass linearly. Another conclusion was that improved engine design had led to significant reductions in particulates which were larger than that seen due to effect of fuel properties. But for low emission production engines fuel quality would play a role.

Amoco Oil Co. and Navistar International Transportation Corp. studied the diesel fuel property effects on exhaust emissions from a heavy-duty diesel engine that met the 1994 emissions requirements in 1992 [13]. The study evolved around determining the effect of cetane number and aromatic on the engine which met the 1994 emissions standard in which no exhaust aftertreatment devices were used. The engine tested upon was a 1993 preproduction Navistar Smokeless Diesel DTA 466 model ES 210 using the EPA transient cycle. They found that increasing cetane number reduced all regulated diesel emissions and reducing 
aromatic content reduced $\mathrm{NO}_{\mathrm{x}}$ and particulate emissions. An important observation made in this study was it would be cost effective if only the cetane number was increased by using fuel additive rather than reducing the aromatic content. When compared to previous studies the effect of cetane in this study was more effective. Also the effect of API gravity was studied which had an effect on $\mathrm{NO}_{\mathrm{x}}$ and $\mathrm{PM}$ (reduction in fuel density reduced $\mathrm{NO}_{\mathrm{x}}$ and $\mathrm{PM}$ ) but increased $\mathrm{HC}$ and $\mathrm{CO}$ emissions.

PM-fuel relations were analyzed by Shell Research Ltd in 1994 [14]. It was reported an increase in density and aromatic content increased brake-specific PM, and increasing cetane number generally decreased PM emission. Lowering the sulfur content of fuel from $0.037 \%$ weight to $0.023 \%$ weight reduced PM emission up to $12 \%$, decreasing density reduced PM by $13 \%$, and cetane increases reduced PM emission by $5 \%$ in a Euro- 1 cycle.

Texaco, Inc. performed a study regarding the effects of diesel fuel on emissions in 1995 [15]. It was concluded fuels with higher cetane number generated lower $\mathrm{NO}_{\mathrm{x}}$ emission levels than lower cetane number fuels when aromatic content was held constant. It was also noted there was little or no $\mathrm{NO}_{\mathrm{x}}$ reduction when high cetane number fuels had their cetane numbers increased naturally or through additives. $\mathrm{HC}$ emissions were found to be unrelated to cetane number. PM emissions were not affected by cetane number fluctuations when under light and medium load, but under high load the PM emissions of higher cetane number fuels were greater than that of low cetane number fuels.

In 1996, a study by Indian Institute of Petroleum on diesel fuel quality and particulate emissions investigated the influence of fuel properties that had an influence on particulate emissions other than the sulfur content which was a significant effect on particulate emissions [16]. Results of various other studies showed that aromatic content had little influence on particulate emissions only in direct injection engines of modern design. This study came to a conclusion that density and oxygen content of the diesel fuel affected the particulates.

The Technical Research Centre of Finland studied the effects of physical and chemical properties of diesel fuel on $\mathrm{NO}_{\mathrm{x}}$ emissions of heavy-duty diesel engines in 1997. The focus of this study was on separation of physical and chemical effects of the fuel on $\mathrm{NO}_{\mathrm{x}}$ formation [17]. A Volvo DH10A-285 bus engine that met the Euro II emissions regulations, (CO 4.0 $\mathrm{g} / \mathrm{kWh}, \mathrm{HC} 1.1 \mathrm{~g} / \mathrm{kWh}, \mathrm{NO}_{\mathrm{x}} 7.0 \mathrm{~g} / \mathrm{kWh}$ and particulates $0.15 \mathrm{~g} / \mathrm{kWh}$ ) was used for testing. 
Four diesel fuels with different density and aromatic levels were used to study the effects of fuel on emissions. They also used reformulated fuels to study their effect on engine emissions. Regulated emissions data were collected over the ECE R49, the European 13-mode emission test cycle. The results concluded that $7-13 \%$ reduction was seen in reformulated fuels in which $75-90 \%$ of the total reduction was due to the physical (density, viscosity) and chemical (aromatics, cetane) properties.

WVU performed extensive studies relating to alternative fuels and their impact on engine emissions in 1999 [18, 19]. Fuels included low sulfur pump diesel, California pump diesel, Malaysian Fischer-Tropsch fuel, soy fuels and biodiesels. Emission reductions were as high as $60 \%$ for $\mathrm{HC}$. $\mathrm{NO}_{\mathrm{x}}$ was reduced in some instances by over $25 \%$ from low sulfur pump fuel, and increases from low sulfur were as high as $11 \%$.

In 2000 the University of Tokushima conducted research on the effects of fuel properties on direct-injection diesel engines [20]. Cetane number and aromatic content were varied independently. It was shown for fuels of like aromatic content, decreasing the cetane number increased ignition delay, decreasing $\mathrm{PM}$ and increasing $\mathrm{NO}_{\mathrm{x}}$ emission. High cetane number fuels were found to increase PM due to an increase in combustion duration. Aromatic content had little effect on combustion quality, but high aromatic content increased both $\mathrm{NO}_{\mathrm{x}}$ and PM emissions. It was also concluded a raise in injection pressure made the effects of cetane number and aromatic content less significant.

A 2003 study performed by the Japan Automobile Research Institute tested 9 fuels, focusing on density and viscosity correlations [21]. The engine of focus was a common rail direct injection diesel, turbocharged and after-cooled. It was found that an increase in density increased brake-specific $\mathrm{PM}$ and decreased brake specific $\mathrm{NO}_{\mathrm{x}}$. An increase in density was also found to lower CO and THC emissions. Little conclusion was drawn on the effects of viscosity, other than an increase lead to an increase in Sauter mean diameter of the fuel spray, increasing PM. 


\subsection{Motivation}

A part of the study made by Gibble [5], who tested commercially available fuels on an engine to evaluate emissions it was determined that variations in engine emissions from in- use fuels were attributed to the differences in the properties of fuel. This was the motive for this study to evaluate emissions between an older technology engine and newer technology using commercially available fuels along with a biodiesel fuel.

Gibble tested commercially available fuels on a 1999 Ford B250 (International T444E) over the US transient FTP cycle, steady state and in-use testing. The test results showed differences in $\mathrm{NO}_{\mathrm{x}}$ of $12 \%, \mathrm{PM}$ of $50 \%, \mathrm{HC}$ of $17 \%$ and $\mathrm{CO}$ of $40 \%$ between the tested fuels. 


\section{EXPERIMENTAL EQUIPMENT AND PROCEDURES}

\subsection{Introduction}

The experimental equipment and procedures used for performing the testing were conducted at the Engine and Emissions Research Laboratory (EERL) at WVU which operates in compliance with CFR 40, Part 86, Subpart N [22]. A summary of the equipment and procedures used is given below.

\subsection{Test Engines}

\subsubsection{Detroit Diesel Series 60}

A turbocharged, direct-injected, in-line six cylinder DDC S60 engine was used for analyzing the exhaust emissions for this study using a DC dynamometer. Table 3-1 displays specifications of the engine and the engine can be seen in Figure 3-1. The engine was mapped from low to high engine speeds with wide open throttle on each fuel for torque and power curves and respective maps were used. Figure 3-2 represents one of the maps used for testing.

\subsubsection{Cummins ISM 370}

A turbocharged, direct injected in-line six cylinder Cummins ISM 370 was also used for analyzing the exhaust emissions for this study using a DC dynamometer. Table 3-1 displays more specifications of the engine and can be seen in Figure 3-3. The engine was mapped for torque and power curves on each fuel and Figure 3-4 represents a map curve.

Table 3-1 Engine Specifications

\begin{tabular}{|c|c|c|}
\hline Engine Manufacturer & Detroit Diesel Corporation & Cummins \\
\hline Engine Model, Year & DDC S60, 1992 & Cummins ISM 370, 2004 \\
\hline Cylinders & 6 & 6 \\
\hline Displacement, L & 12.7 (775 CID) & 10.8 (661 CID) \\
\hline Power Rating (hp) & 360 & 370 \\
\hline Torque Rating (ft-lb) & $1450 @ 1200$ rpm & $1450 @ 1200$ rpm \\
\hline Bore (mm) X Stroke (mm) & 130 X 160 147 \\
\hline Compression Ratio & $15: 1$ & $16.5: 1$ \\
\hline Air Handling & Turbocharged, Aftercooled & Turbocharged, Aftercooled \\
\hline Exhaust Gas Recirculation (EGR) & N/A & Cooled EGR \\
\hline
\end{tabular}




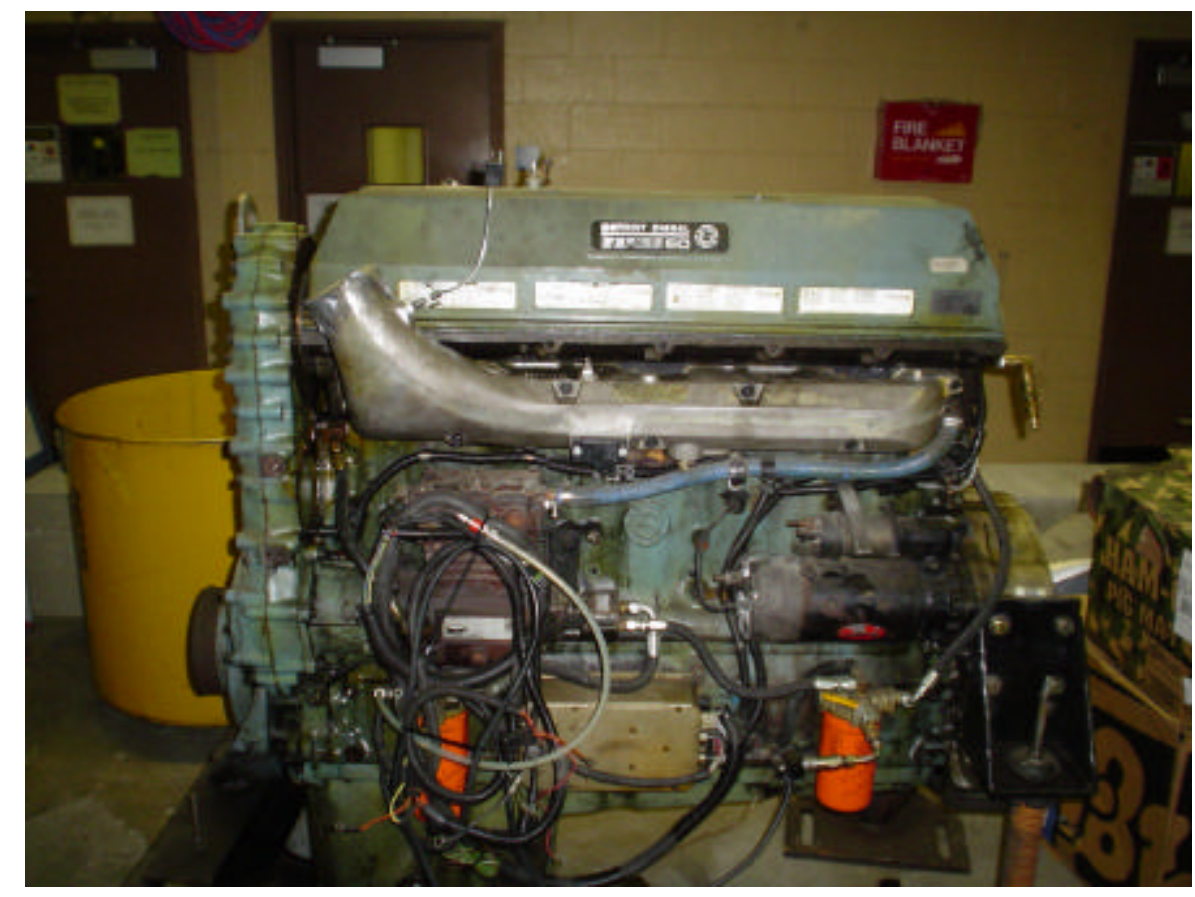

Figure 3-1 1992, DDC S60

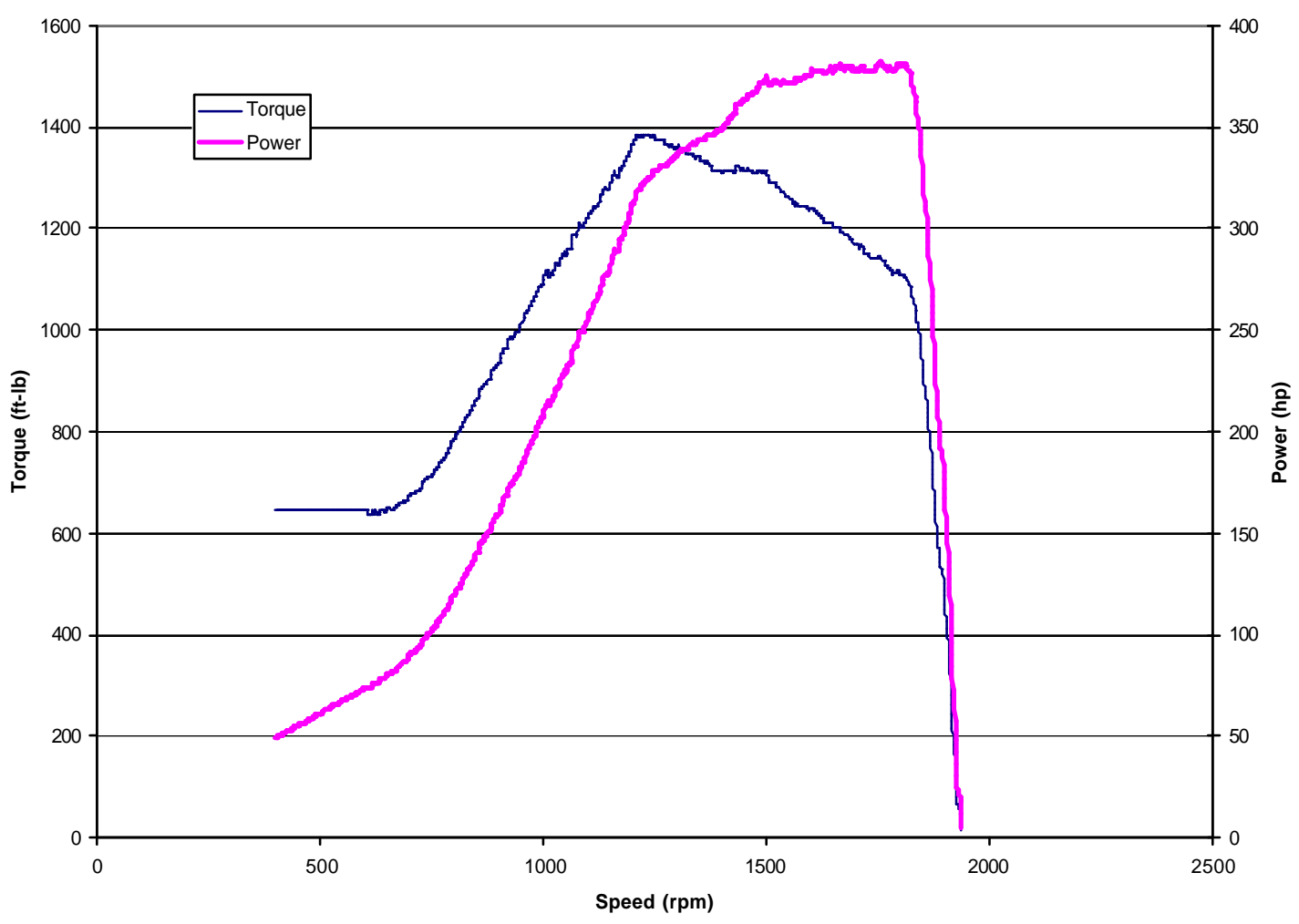

Figure 3-2 DDC S60 Engine Map 


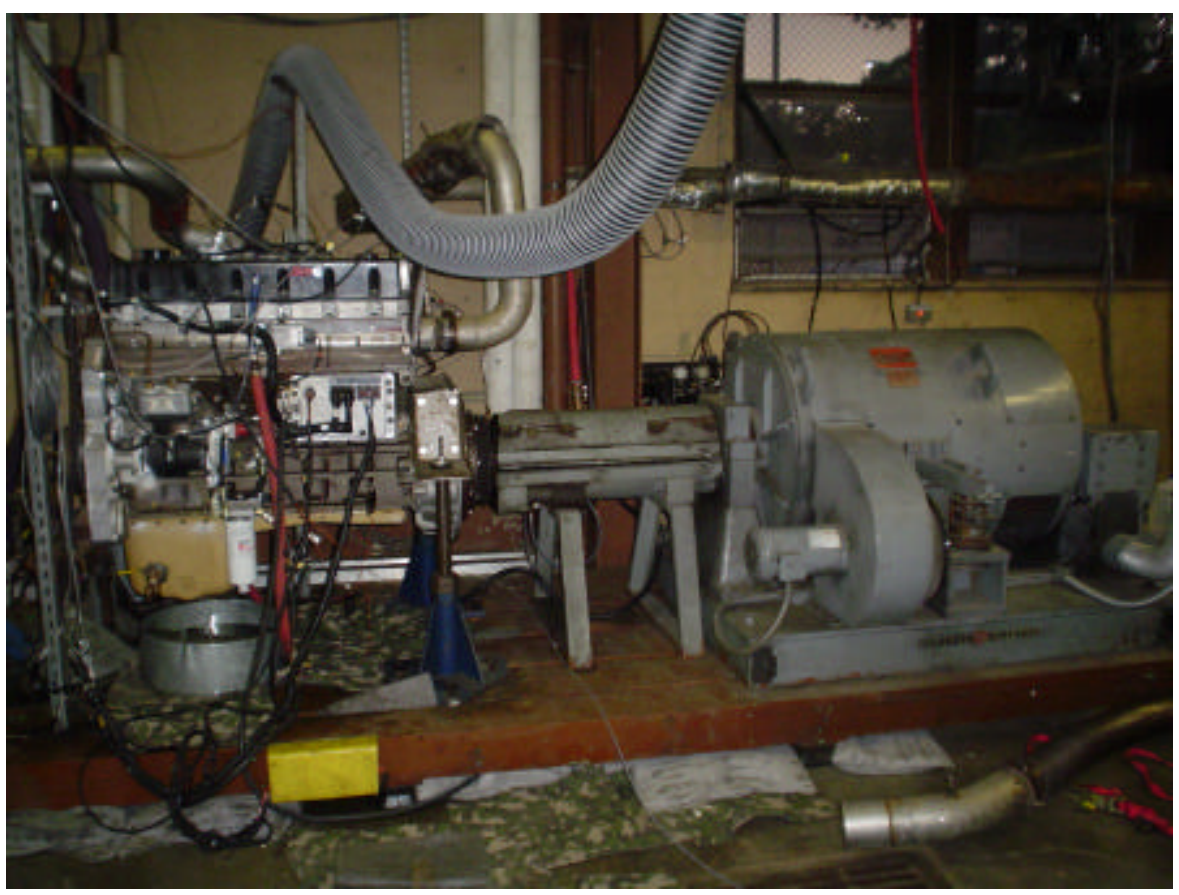

Figure 3-3 Cummins ISM 370 connected to the GE Engine Dynamometer

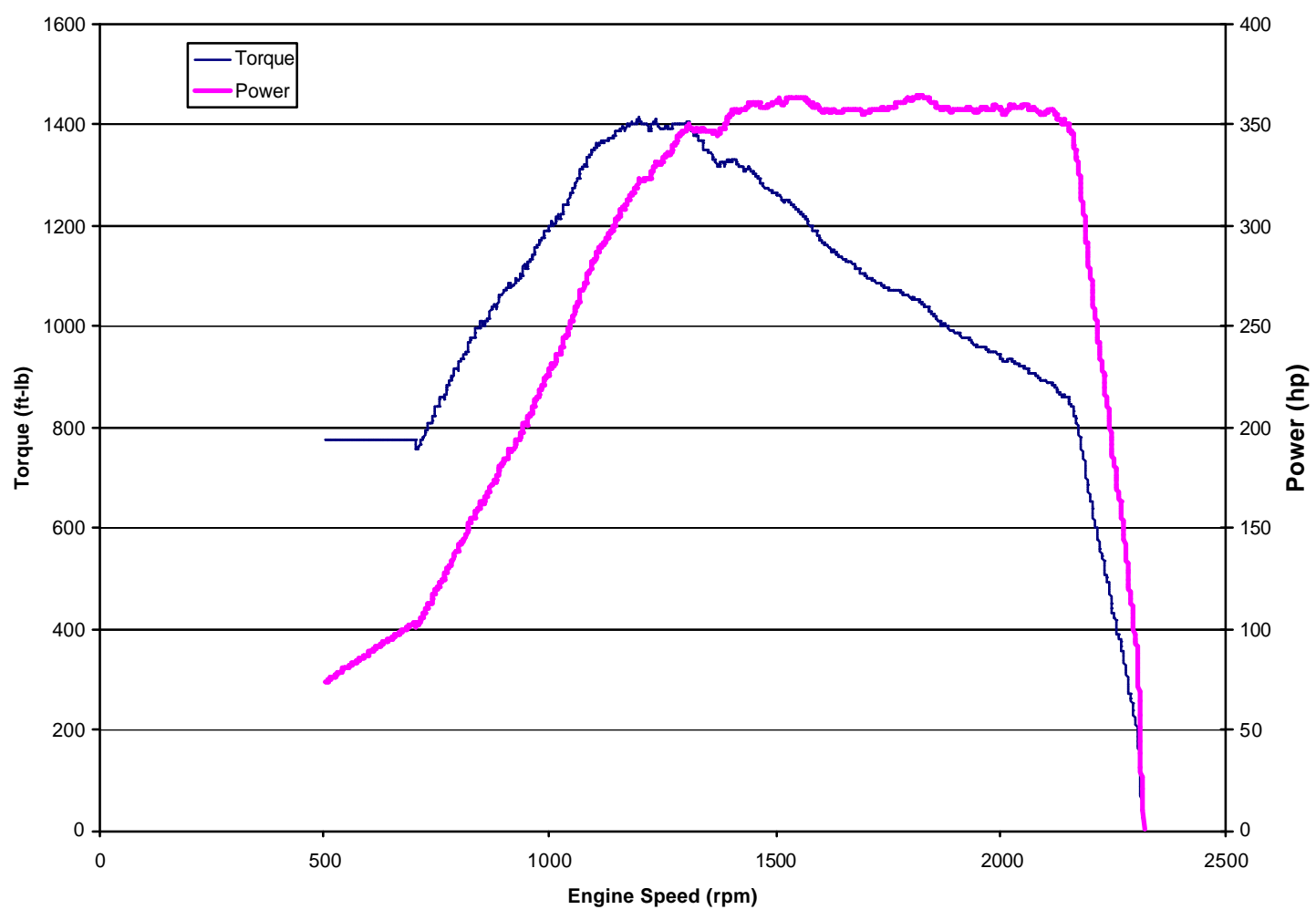

Figure 3-4 Cummins ISM 370 Engine Map 


\subsection{Engine Dynamometer}

Dynamometers serve the purpose of loading the engines to simulate the load conditions used for engine dynamometer cycle testing. The dynamometer used for testing in this study at EERL was a General Electric direct current Model DYC 243 air cooled and is shown in Figure 3-3. The dynamometer has a capacity of absorbing up to 550hp and capable of motoring the engine up to 500hp. Once the dynamometer was coupled to the engine using Vulkan coupling and drive shaft, it was imperative to measure the torque which was achieved by using a load cell. The dynamometer was calibrated before the testing so as to make sure that it was in compliance with the testing procedures according to the CFR 40, Part 86, Subpart N. Engine speed was measured using a digital encoder mounted on the dynamometer.

\subsection{Full Flow Dilution Tunnel}

Whenever emission testing is performed it is important to simulate the real world conditions so as to analyze the effects of exhaust emissions on the environment. A full flow dilution tunnel serves the purpose of diluting the exhaust and preventing condensation by lowering of dewpoint of the dilute stream. The importance of preventing condensation is to avoid water droplets getting into sampling lines and affecting the analyzers and also to avoid absorption of gases such as $\mathrm{NO}_{2}$.

The dilution tunnel at EERL was an 18 inch stainless steel and approximately 40 feet in length. A $75 \mathrm{hp}$ blower was used to draw diluted engine exhaust through four critical flow venturis (one $400 \mathrm{scfm}$ and three 1000scfm) with flow rates ranging from 400 to $3400 \mathrm{scfm}$ and also provided a constant volume sampling (CVS) system. A mixing orifice was placed in the tunnel to assist in mixing of engine exhaust and dilution air. At 10 diameters downstream of the orifice the sampling probes were located to collect the dilute engine exhaust for analysis through heated sample lines (to prevent condensation) connected to analyzing instruments. 


\subsection{Critical Flow Venturi}

The critical flow venturi (CFV) system used at WVU EERL was in compliance with the CFR 40, Part 86, Subpart $\mathrm{N}$ for the diluted exhaust flow. The laboratory used three venturis with a volume metric flow rate of $1000 \mathrm{scfm}$ each and a $400 \mathrm{scfm}$ to maintain a constant total flow rate. The CFV were based on the principle that the mass flow rate of a gas was maintained at a constant value once the gas flow reached sonic conditions. The mass flow through the venturi was calculated using the equation

$$
\mathrm{Q}=\mathrm{K}_{\mathrm{v}} \frac{P}{\sqrt{T}} \quad \text { Equation (3) }
$$

Where $\mathrm{Q}$ was the mass flow rate (scfm), $\mathrm{K}_{\mathrm{v}}$ was a calibration coefficient, $\mathrm{P}$ was the absolute pressure at the inlet of the venturi (in $\mathrm{Hg}$ ), and $\mathrm{T}$ was the absolute temperature of the gas at the inlet of the venturi $\left({ }^{\circ} \mathrm{F}\right)$. The flow rate used for this study was set to $2400 \mathrm{scfm}$.

\subsection{Gaseous Emission Sampling System}

The gaseous sampling system at the WVU EERL consists of heated sampling probes, heated sampling lines, heated pumps, heated filters, a chiller unit and gas analyzers. Stainless steel sampling probes were placed radially in the sampling plane at 10 diameters down the orifice of the dilution tunnel to sample required proportion of the diluted exhaust to the analyzers through pumps. Four probes are used - one each for $\mathrm{HC}, \mathrm{NO}_{\mathrm{x}}, \mathrm{NO}_{\mathrm{x}} 2$ and $\mathrm{CO} / \mathrm{CO}_{2}$. According to the CFR 40, Part 86, Subpart N, the temperatures of the heated sample lines were held constant by temperature controllers $\left(\mathrm{HC}-375 \pm 20^{\circ} \mathrm{F}, \mathrm{NO}_{\mathrm{x}}-235 \pm 20^{\circ} \mathrm{F}, \mathrm{CO} / \mathrm{CO}_{2}-\right.$ $235 \pm 20^{\circ} \mathrm{F}$ ) to prevent condensation in the sample lines. The heated sample for $\mathrm{HC}$ analyzer was maintained at higher temperature than the other lines to insure that heavy hydrocarbons did not condense in the sample line. The $\mathrm{CO} / \mathrm{CO}_{2}$ sample was pumped through a Dominic Hunter compressed air dryer to remove moisture from the sample. 


\subsection{Exhaust Gas Analyzers}

The emissions analyzer bench at the WVU EERL contained analyzers manufactured by Rosemount Analytical, Inc, Horiba and Eco Physics as shown in Figure 3-5, which were capable of measuring $\mathrm{HC}, \mathrm{CO}, \mathrm{CO}_{2}$ and $\mathrm{NO}_{\mathrm{x}}$. Also included in the bench was a Beckman $\mathrm{NO}_{\mathrm{x}}$ efficiency tester, used for testing the converter efficiency in the $\mathrm{NO}_{\mathrm{x}}$ analyzer. The following sections discusses in brief about the principle of operation and their specifications.

\subsection{Hydrocarbon (HC) Analyzer}

A Rosemount Model 402 Heated Flame Ionization Detector was used to measures the hydrocarbon concentration of the engine exhaust. A flame ionization detector operates on the principle of using polarized electrodes to collect positive ions. A regulated flow of the sample gas was introduced to the instrument. The sample then passed through a flame, fueled by a combination of $40 \%-60 \%$ hydrogen and helium. As the sample passed through the flame, hydrocarbons initiate an ionization process in which electrons and positive ions were produced. Electrons went to the positive electrode (anode), while the positive ions migrated to the negative electrode (cathode). A small ionization current, which was proportional to the concentration of carbon atoms passed between the two electrodes. An amplified analog voltage is read which was proportional to the current being generated. The Model 402 measured concentrations ranging from 1 to $5,000 \mathrm{ppm}$ which was selected using a multiplier switch located in the front of the analyzer.

\subsection{Oxides of Nitrogen $\left(\mathrm{NO}_{\mathrm{x}}\right)$ Analyzer}

A Rosemount Model 955 heated chemiluminescent analyzer was used to measure the $\mathrm{NO}_{\mathrm{x}}$ in the exhaust mixture. Chemiluminescence is a process of photon emission during a chemical reaction which results when $\mathrm{NO}$ reacts with Ozone $\left(\mathrm{O}_{3}\right)$. Ozone $\left(\mathrm{O}_{3}\right)$ was generated by the ultraviolet irradiation of oxygen in a quartz tube. Excess $\mathrm{O}_{3}$ was present to ensure complete reaction and to minimize quenching effects. A photo-multiplier tube enhanced the light intensity, where a photo-detector converted into voltage proportional to the number of NO molecules in the sample. Sample pressure and flow rate was carefully monitored before and after testing to ensure proper readings. An analog output voltage between $0-5 \mathrm{~V}$ was 
measured representing the zero and full scale calibration gas concentration. It is known that a significant portion of $\mathrm{NO}_{\mathrm{x}}$ in diesel exhaust can be $\mathrm{NO}_{2}$. Therefore, the Model 955 reduced $\mathrm{NO}_{2}$ in the sample to $\mathrm{NO}$ through the use of a $\mathrm{NO}_{2}$-to-NO converter. The NO produced in the converter was then reacted with $\mathrm{O}_{3}$ in the same manner as the original NO in the sample to give a total $\mathrm{NO}_{\mathrm{x}}$ measurement. If only a $\mathrm{NO}$ measurement was desired, then the analyzer could have been switched to NO mode, in which the sample bypassed the converter. The Model 955 analyzer could measure $\mathrm{NO}_{\mathrm{x}}$ concentrations in full-scale ranges from 10 to 10000ppm. Along with the Rosemount Model 955, an Eco Physics NOx analyzer was also used.

\subsection{Carbon Monoxide (CO) and Carbon Di oxide $\left(\mathrm{CO}_{2}\right)$ Analyzer}

A Horiba AIA-210 non-dispersive infrared analyzer (NDIR) was used to measure CO and $\mathrm{CO}_{2}$ concentrations. The principle of operation is based on infrared absorption spectrum of gases. The analyzer passes infrared radiation through two cells; one cell containing reference gas and the other containing the sampling gas. At certain frequencies in the infrared spectrum, the energy associated with photon coincides with that required to change a molecule from one quantized energy level to another. At those frequencies a gas will absorb radiation.

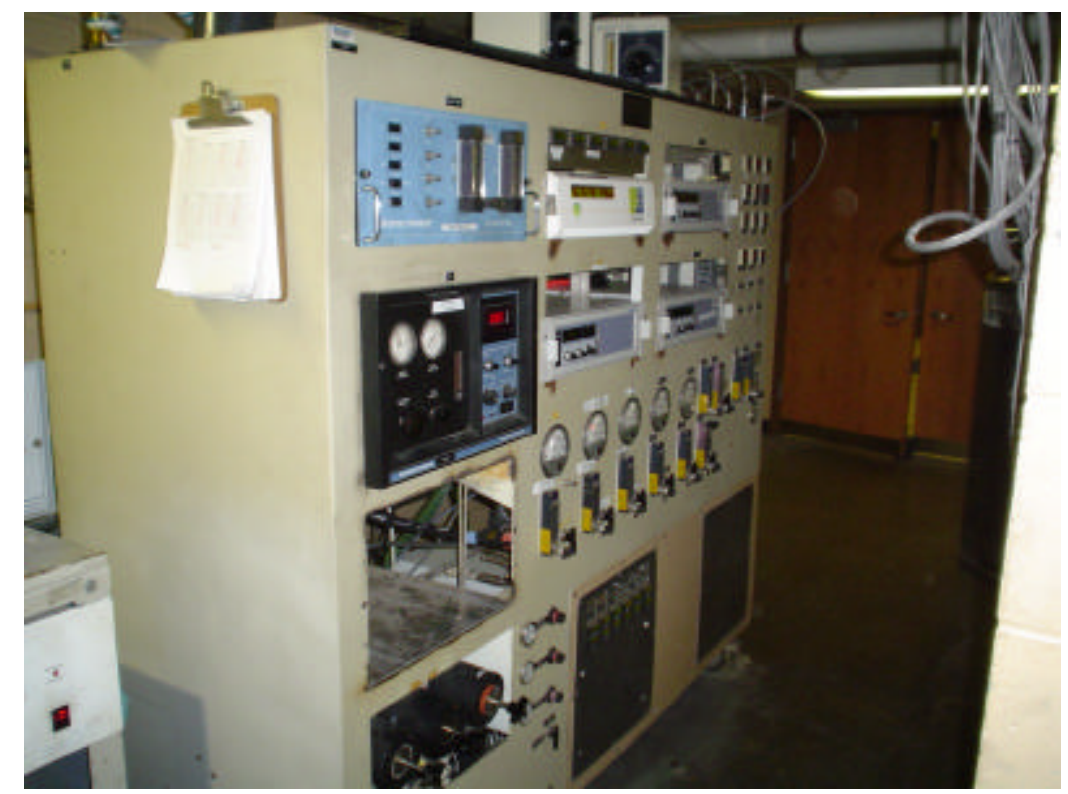

Figure 3-5 Analyzer Bench 


\subsection{Bag Sampling}

Dilute and background gas samples were collected in 80-liter Tedlar bags at the WVU EERL for integrated emission analysis. Dilute bag samples were drawn from the probe located at the sampling plane through Teflon tubing. The background sample of conditioned air were drawn upstream of the dilution tunnel before the introduction of exhaust in the dilution tunnel.

The bags were analyzed using the same emissions analyzers described previously, recorded through the data acquisition system (which is discussed in the following section in this chapter) and then evacuated. Background measurements were subtracted from the exhaust measurements to account for exhaust constituents present in the ambient dilution air.

\subsection{Fuel and Air Flow Metering}

Accurate measurement of fuel and air flow is a pertinent part of engine emissions testing. Engine air intake flow, exhaust flow, and fuel flow must be set accordingly. Fuel metering in the WVU EERL were done with a Max Machinery, Inc. Max Model 710 fuel conditioning system. The fuel measurements were obtained through data acquisition computer which was interfaced with the fuel system for accurate measurements. The fuel measurement system consists of a constant volume fuel tank, fueling supply and return lines, fuel pump, fuel meter, and heat exchanger. The intake air flow rate to the engine was measured using a Meriam Instruments laminar flow element (LFE). The differential pressure across the LFE, along with the absolute pressure, temperature and relative humidity (Omega, HX52) of the air at the inlet, was measured and related to the flow. The intake pressure was adjusted with a butterfly valve placed upstream of the laminar flow element. Likewise, a butterfly valve was placed in the exhaust piping close to the engine to adjust exhaust backpressure to the manufacturer's specification.

\subsection{Instrumentation Control and Data Acquisition}

The laboratory data collected in this experiment was obtained using the software and data acquisition hardware of the WVU EERL which is shown in Figure 3-6. The data was collected using a signal conditioning backplane with Analog Devices 3B system modules and 
RTI-815 analog-to-digital converter data acquisition boards housed inside of the computer [23]. The data was recorded in ADC code. It was later reduced using in-house software to convert it into engineering units.

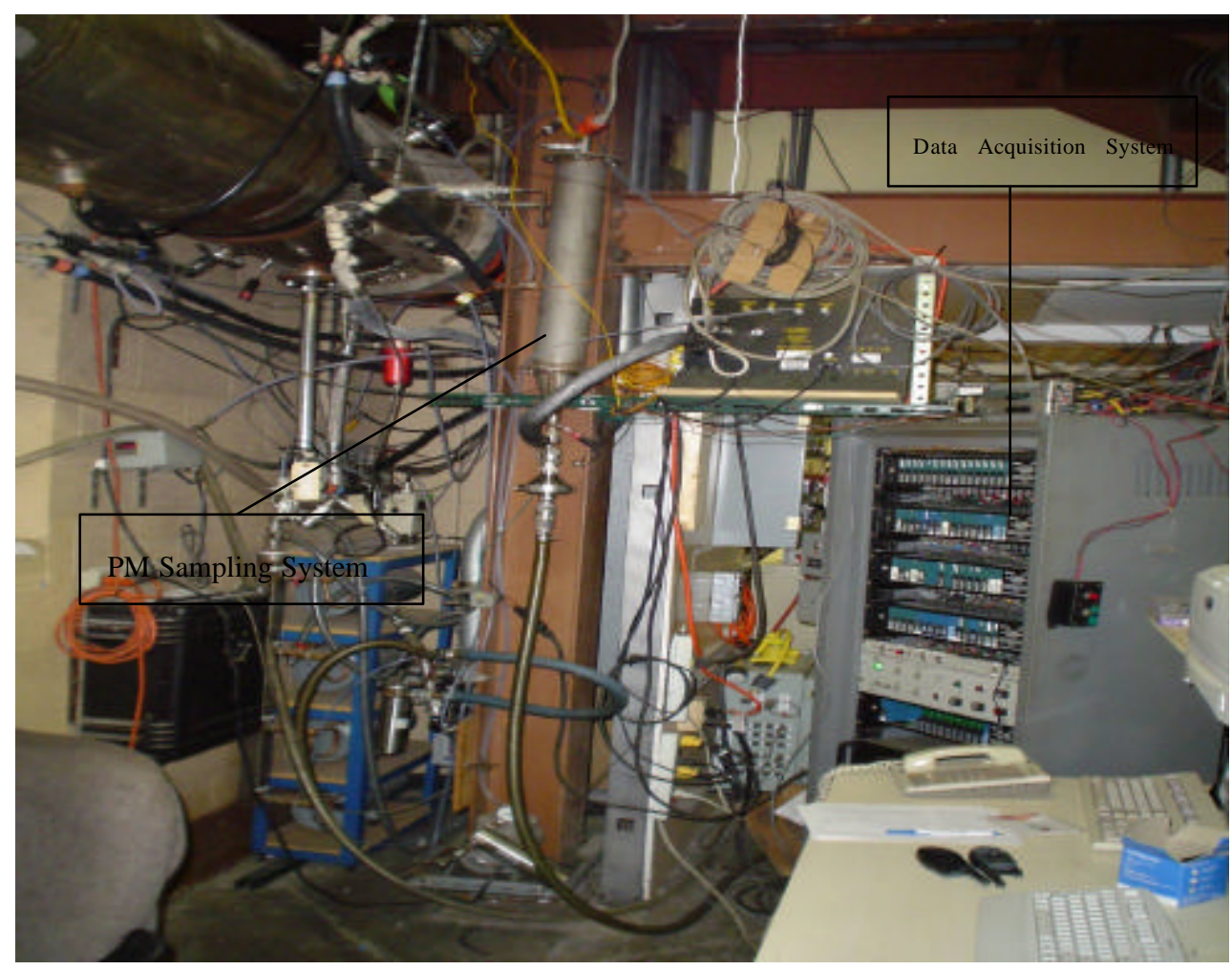

Figure 3-6 Data Acquisition and PM Sampling

\subsection{PM Sampling}

A proportional sampling of the diluted exhaust passes through a filter holder containing a primary and a secondary T60A20 70mm Pallflex fluorocarbon coated glass filter shown in Figure 3-6. The sample was drawn from the dilution tunnel at the sampling plane at the same location as the gaseous emissions lines. The maximum filter face temperature was maintained below $125^{\circ} \mathrm{F}$ during testing per the requirements of the CFR 40, Part 86. Filters were preconditioned for a minimum of an hour in a temperature and humidity controlled environment with temperature maintained at $71.6 \pm 5^{\circ} \mathrm{F}$ and relative humidity of $45 \pm 8 \%$. A Mettler Toledo UMX2 microbalance shown in Figure 3-7, with a resolution of $0.1 \mu \mathrm{g}$ was used for filter weighing. Prior to each weighing session, a calibration was performed and reference filters were weighed. Two reference filters were weighed and used for a month to 
check for varying room conditions. The references filters were subjected to a maximum weight change of 40 micrograms.

Following each test, the filters were conditioned to chamber conditions for minimum of an hour before being finally weighed. Background PM data was collected at the end of each day and background PM weight was subtracted from the total PM weight for each cycle.

In the case of steady state cycles, a solenoid controlled bypass system was setup to maintain a constant sample flow through the secondary dilution tunnel for the duration of the test. During the stabilization phase, a large replaceable fibrous filter was used to collect PM.

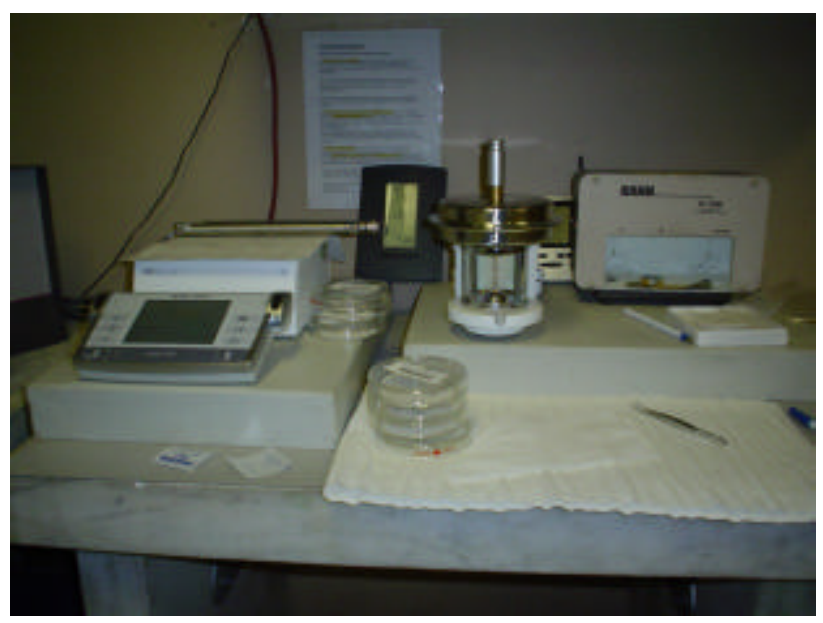

Figure 3-7 Mettler Toledo UMX2 Microbalance

\subsection{Tapered Element Oscillating Microbalance (TEOM)}

A Rupprecht \& Patashnick Co., Inc. TEOM Series 1105, Diesel Particulate Mass Monitor was used in this experiment to acquire the real time PM data, shown in Figure 3-8. The TEOM incorporated a tapered element which was mounted at the wide end and a Pallflex TX 40 filter on the other narrow free end. The tapered element was mounted between two field plates to induce and control oscillation. A LED and phototransistor system was used to measure the frequency of the tapered element in the form of AC signal. The signal was amplified and converted to a mass value using a microprocessor algorithm. A sample of 2.0 lpm was drawn from the secondary dilution tunnel and the real time PM data was collected 


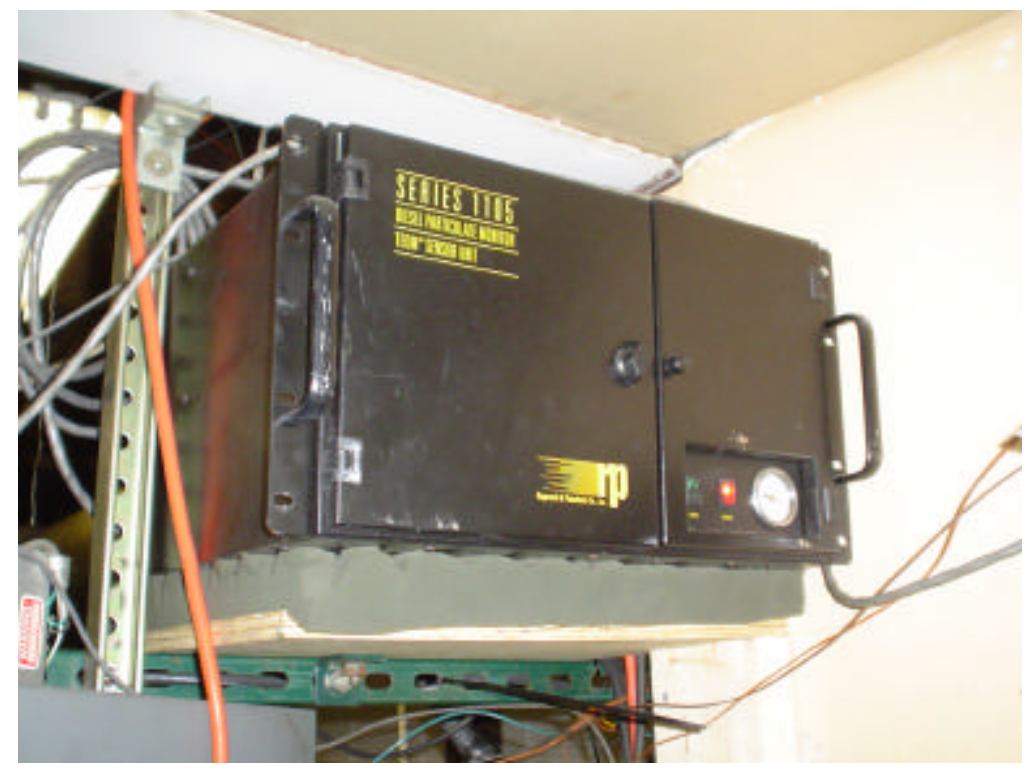

Figure 3-8 Tapered Element Oscillating Microbalance

\subsection{Quality Control and Quality Assurance Procedures}

Laboratory checks were performed in accordance with CFR 40 Part 86, Subpart N including propane injections, NOx efficiency, interference checks for analyzers and pressure leak and temperature checks for heated lines. Interference checks were made in order to insure that the analyzers were not affected by other sample gases. Oxygen interference and water interference tests were performed on the hydrocarbon and $\mathrm{CO}$ analyzer respectively. Pure oxygen was supplied to check the percentage of oxygen interference in the hydrocarbon analyzer. As specified by CFR Title 40 part 86 subpart $\mathrm{N}$ the percentage of oxygen interference should be less than $3 \%$ in a hydrocarbon analyzer. For the water and $\mathrm{CO}_{2}$ interference test on $\mathrm{CO}$ analyzer, $3 \% \mathrm{CO}_{2}$ gas was passed through a water bubbler unit to the $\mathrm{CO}$ analyzer. As specified by CFR Title 40 part 86, the analyzer response should not be more than $1 \%$ of full scale for ranges above $300 \mathrm{ppm}$ or more than $3 \mathrm{ppm}$ on ranges below 300 ppm.

\subsection{Calibration of Analyzers}

Calibration procedures utilized by the WVU EERL were in accordance with the requirements of CFR 40, Part 86, Subpart N. The gases used to calibrate the exhaust analyzers were certified by the supplier to have an accuracy of $1 \%$, traceable to NIST. No gas bottle was 
used if the pressure dropped below 250 psig. The calibration gases were checked with Standard Reference Material (SRM) bottles to see if the bottles were named properly. All exhaust gas analyzers were calibrated using ranges of operation that were in accordance with the engine being tested. These calibrations were performed before each series of tests and after any instrument maintenance was been performed. A 10-point calibration procedure was carried out using a 10-point gas divider. The divider accurately produced varying concentration of component gas in $10 \%$ increments by mixing the span gas with a balance zero reference gas. The instrument readings were allowed to stabilize at each measurement point and a computer averaged (100 points) reading of the instrument response was recorded. These data points and corresponding gas concentrations were fitted to with up to a third degree polynomial and constituted that particular analyzer's calibration data file. The calibration gases used are shown in

Table 3-2 Calibration Gases Used for Testing

\begin{tabular}{|c|c|c|}
\hline Calibration Gases & DDC S60 & Cummins ISM 370 \\
\hline $\mathrm{HC}(\mathrm{ppm})$ & 10 & 10 \\
\hline $\mathrm{NO}_{\mathrm{x}}(\mathrm{ppm})$ & 508 & $171.3,350.6$ \\
\hline Low CO $(\mathrm{ppm})$ & 500 & 49.98 \\
\hline High CO $(\mathrm{ppm})$ & 979 & 250.3 \\
\hline $\mathrm{CO}_{2}(\mathrm{ppm})$ & 40110 & 48110 \\
\hline
\end{tabular}

\subsection{Propane Injections}

To verify the accuracy of the CFV-CVS system, propane injections were performed where propane was injected into the dilution tunnel at a known rate using a Horiba Model 201B propane kit. The amount of propane injected was compared with the calculated amount indicated by a hydrocarbon analyzer. The difference between the volumes of propane injected to recovered measure by the analyzer must be lower than $2 \%$. Three successive injections which fell within the $2 \%$ with not more than $0.5 \%$ differences between successive injections were considered valid to ensure accuracy of the CFV- CVS. 


\subsection{NOx Efficiency Test}

This test was performed to ensure efficiency of the converter in the $\mathrm{NO}_{\mathrm{x}}$ analyzer in efficiently converting $\mathrm{NO}_{2}$ to $\mathrm{NO}$ such that the chemiluminescent detector can properly measure $\mathrm{NO}_{\mathrm{x}}$. The Rosemount Analytical Model $955 \mathrm{NO} / \mathrm{NO}_{\mathrm{x}}$ analyzer does not detect $\mathrm{NO}_{2}$, because it does not undergo the reaction with $\mathrm{O}_{3}$ as $\mathrm{NO}$. Therefore the $\mathrm{NO}_{2}$ has to be converted to $\mathrm{NO}$ through the $\mathrm{NO}_{2}$ to $\mathrm{NO}$ converter. This converter was checked at a monthly basis in EERL using a known concentration of NO gas. This efficiency test was also performed on the Eco Physics $\mathrm{NO}_{\mathrm{x}}$ analyzer used during testing. 


\section{TEST CYCLES}

For emissions certifications of on-road diesel engines the engines are tested on the US transient (FTP) cycle. Additionally, engine manufacturers most now exercise their engines over the ESC cycle as part of the certification test procedure. Along with these standard cycles, on-road cycles were also used to study fuel effect from those cycles.

\subsection{Federal Transient Procedure (FTP)}

One of the prominent transient cycles used to test HDDE to analyze emissions that simulates closely to that of the real-time on-road conditions is the FTP. FTP simulates the styles of urban and freeway driving cycles. FTP is based on Urban Dynamometer Driving Schedule (UDDS) for HDDE.

The FTP cycle is divided into four phases to completely simulate the various driving situations on road. The four phases included are the New York Non Freeway (NYNF) phase which represents light urban traffic with frequent stops, the Los Angeles Non Freeway (LANF) phase which represent busy urban traffic with few stops, the Los Angeles Freeway (LAFY) phase that simulates the busy freeway traffic and the last phase is the NYNF phase [24].

The FTP input file consisted of set points which was generated from the percentages of engine speeds and torques from the engine map generated from on each fuel. The emissions were reported on a brake specific basis to account for the variety of engine sizes. For testing purpose a minimum of three hot starts cycles were carried out. The test duration for each hot start consisted of 40 minutes of which the first 20 minutes consisted of soak time where the engine was not running and next 20 minutes where engine was running. Figure 4-1 shows target engine speed versus time and Figure 4-2 shows target engine torque verses time trace for the FTP cycle adapted to the DDC Series 60 based on the information from the DDC Series 60 engine map. 


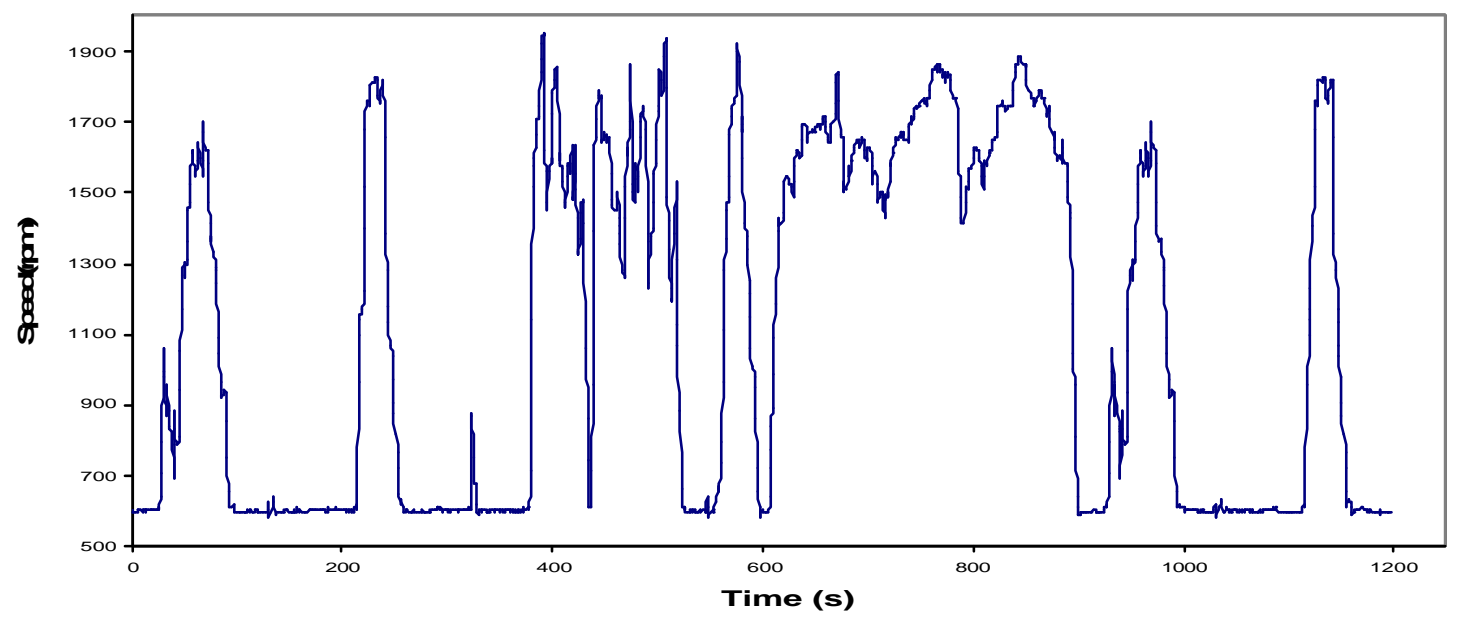

Figure 4-1 Engine Speed versus Time for the FTP Cycle for a DDC S60

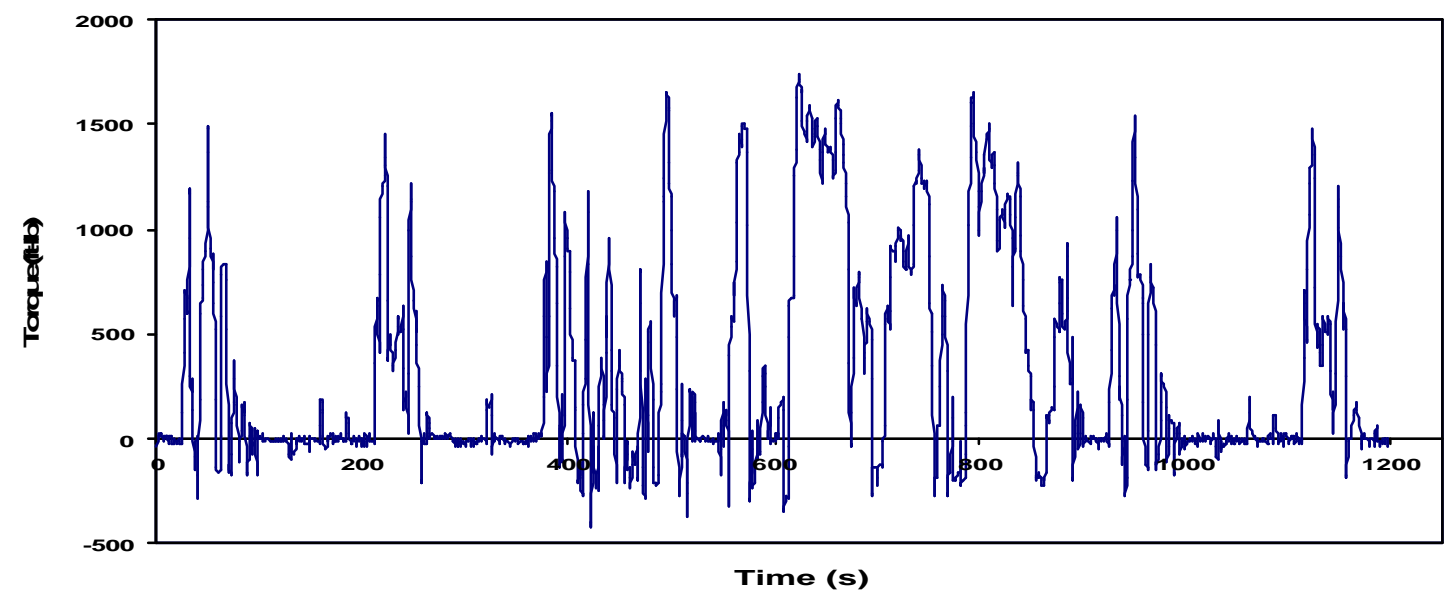

Figure 4-2 Engine Torque versus Time for the FTP Cycle for a DDC S60

\subsection{European Stationary Cycle (ESC)}

The ESC is a 13-mode, steady state cycle which is used for emissions certification The engine is tested on an engine dynamometer over a sequence of steady-state modes as shown in Table 4-1, which was one of the input files used for this testing. The engine was operated for a set time in each mode, where engine speed and load changes were first allowed to stabilize before the gas data and PM data was collected. The specified speed is held to within $\pm 50 \mathrm{rpm}$ and the specified torque $\pm 2 \%$ of the maximum torque at the test speed. Particulate matter emissions were sampled on one filter over the 13 mode. The weighted emissions were expressed in brake specific units and for individual mode in terms of $\mathrm{g} /$ mode for gas data. The engine was mapped on each fuel and the percentage engine speed and torque 
values were recorded which was later used to configure the set points for the input file. One such representative input file generated is attached in Appendix A.

Table 4-1 Example Set Points for 13-Mode ESC for a DDC S60

\begin{tabular}{|c|c|c|c|}
\hline Mode & Engine Speed & Load & Weighing Factor (\%) \\
\hline 1 & 600 & 1310 & 10 \\
\hline 2 & 1200 & 619 & 10 \\
\hline 3 & 1423 & 929 & 8 \\
\hline 4 & 1423 & 655 & 5 \\
\hline 5 & 1200 & 983 & 5 \\
\hline 6 & 1200 & 328 & 9 \\
\hline 7 & 1200 & 1238 & 10 \\
\hline 8 & 1423 & 310 & 8 \\
\hline 9 & 1423 & 1142 & 5 \\
\hline 10 & 1645 & 286 & 5 \\
\hline 11 & 1645 & 857 & 5 \\
\hline 12 & 1645 & 571 & 5 \\
\hline 13 & 1645 & & 5 \\
\hline
\end{tabular}

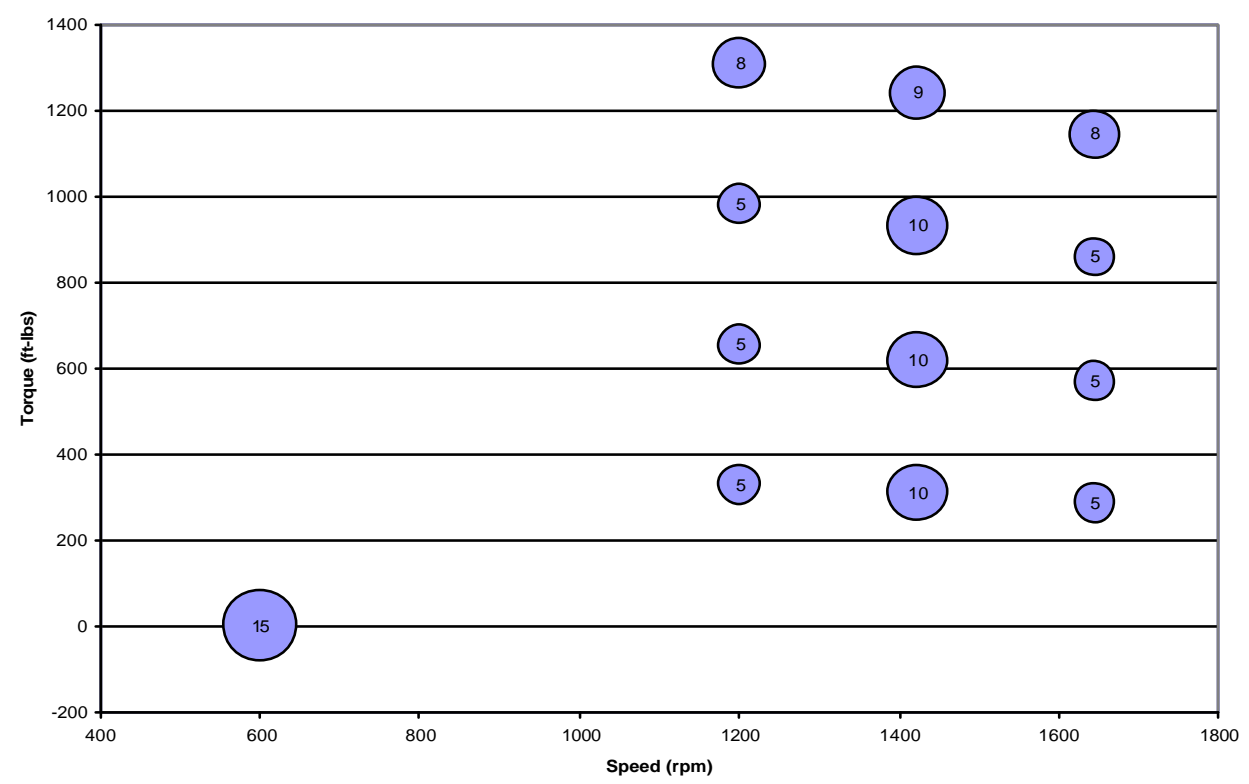

Figure 4-3 Example ESC Set Points and Weighting Factors 


\subsection{On-Road Cycles}

\subsubsection{Bruceton Mills, WV}

This route is designated by SAB2BM which was used in MEMS Phase-II as an onroad route for testing. The actual route consists of an outbound and return journey. The outbound journey will be discussed. This route originated from the former WVU facility close to Sabraton entrance ramp on I-68 east, and continues onto I-68 where a climb of 5\% grade exists, followed by up and down grades to Bruceton Mills, WV. The distance traveled on this route is 39.7 miles with speed limit of $70 \mathrm{mph}$ on the interstate [3]. Figure 4-4 displays the engine speed and torque values versus time for the SAB2BM cycle. The speed and torque setpoints used for this cycle were taken from a 1994, DDCS60 engine with maximum torque rating being the same as the DDCS60 used for this testing but a slightly higher power of 400hp. The setpoints used from 1994, DDC S60 are closed matched by 1992 DDC S60 during cycle comparisons. Hence the setpoints were used for on-road cycle which represents a real time conditions.

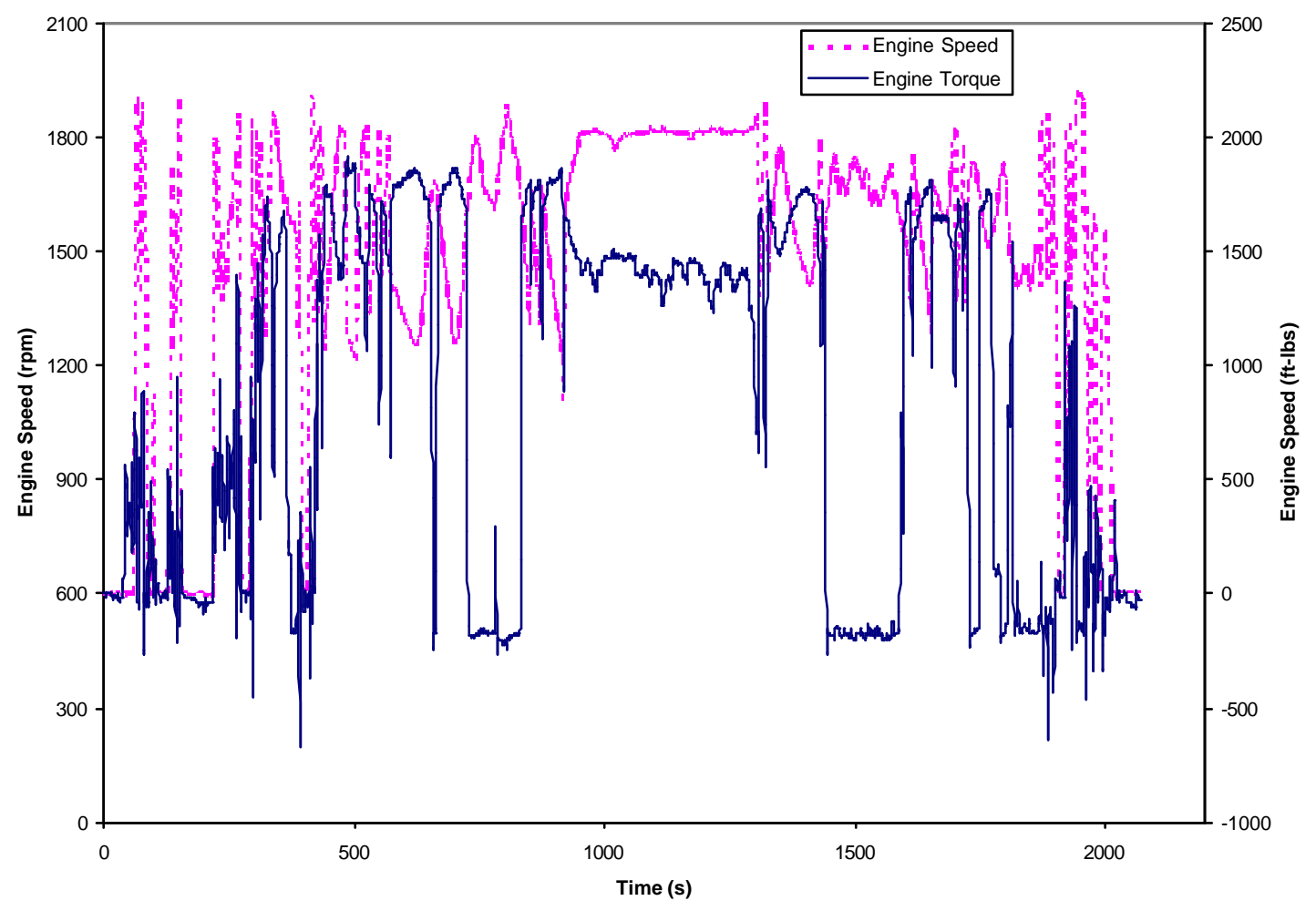

Figure 4-4 Engine Speed and Torque versus Time for the SAB2BM Route Cycle 


\subsubsection{ISM HH4}

The ISM HH4 was an engine-dynamometer cycle, recreated from a normal duty cycle of a Heavy Hauler which was taken from in-field data. The engine speed, torque and other parameters were acquired using a data acquisition system connected to the ECM This cycle was recreated so that the cycles were of shorter duration and could be loaded on to an DAQ computer using the facilities at EERL [25].

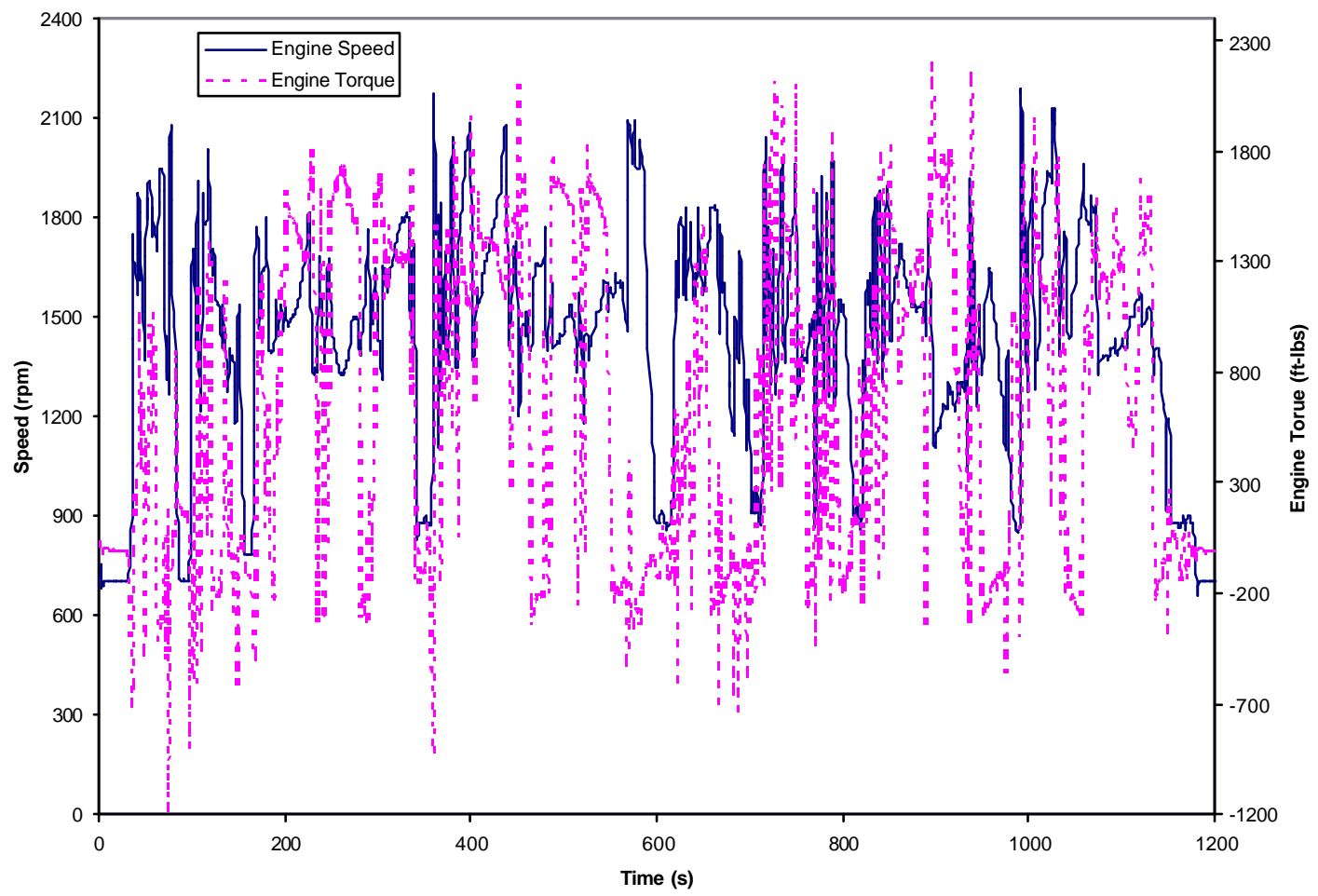

Figure 4-5 Engine Speed and Torque versus Time for the ISM HH4 Route Cycle 


\section{RESULTS AND DISCUSSION}

\subsection{Test Fuels}

Eight fuels were examined for this study which included seven commercially available No.2 diesel fuels and a biodieselblend (B20) fuel. The diesel fuels used in previous studies on effect of fuel properties on emissions have tested reformulated diesel fuels and only some of the studies have used commercially available fuels. The fuels were drawn out of stations from two different states, West Virginia and California, which have differences in fuel properties.

Three diesel fuels were drawn from local gas stations in Morgantown, West Virginia. Two fuels were drawn from Sheetz and Kroger gas stations in Sabraton. The third fuel was a British Petroleum (BP) drawn from the station on the Mileground. Two other fuels used for testing were from California State, of which one of the m was from Shell branded fuel from Bakersfield and the other CECD. Guttman-1 and Guttman-2 diesel fuels are the No.1 diesel fuels used for engine dynamometer cycle testing in WVU EERL. A B20 blend was prepared by blending $80 \%$ of Guttman- 2 diesel fuel along with $20 \%$ of biodiesel.

Fuels samples were collected at the end of testing and stored in one gallon containers designated with a WVU Number (for example WVU F0302) for identification For consistency in analysis results of the fuels, all the samples were sent to Southwest Research Institute (SwRI) in San Antonio, Texas.

The California fuels had lower sulfur content in them when compared to fuels from the state of West Virginia. The Shell Bakersfield had very high nitrogen content when compared to the other fuels. The total aromatics varied between $10(\% \mathrm{wt})$ to $30(\% \mathrm{wt})$ over all the fuels. The cetane numbers for the Guttman-1 and Guttman-2 were high when compared to other fuels ranged between 60 and 65 .

The fuel analysis obtained for all fuels from SwRI is displayed in Table 5-1, along with standards by which they were analyzed. The average values of all the fuel properties analyzed, along with variation is attached in Appendix B. The correlation between the fuel properties is shown in the results and discussion chapter. 
Table 5-1 Fuel Analysis Results

\begin{tabular}{|c|c|c|c|c|c|c|c|c|c|}
\hline \multirow{2}{*}{ ASTM Method } & \multirow{2}{*}{ Fuel Property } & WVF0304 & WVF0303 & WVF0302 & WVF0301 & WVF0305 & WVF0306 & WVF0307 & WVF0439 \\
\hline & & Sabraton Kroger & Guttman-1 & Shell Bakersfield & CECD1 & Sabraton Sheetz & Mileground BP & Guttman-2 & Biodiesel \\
\hline ASTM D2622 & Sulfur (ppm) & 293.0 & 455.0 & \begin{tabular}{|l|}
166.0 \\
\end{tabular} & 207.0 & \begin{tabular}{|l|}
418.0 \\
\end{tabular} & \begin{tabular}{|l|}
397.0 \\
\end{tabular} & \begin{tabular}{|l|}
384.0 \\
\end{tabular} & 306.0 \\
\hline ASTM D1298 & Specific Gravity & 0.856 & 0.810 & 0.843 & 0.837 & 0.859 & 0.851 & 0.814 & 0.828 \\
\hline ASTM D287 & API Gravity & 33.9 & 43.2 & 36.4 & 37.6 & 33.2 & 34.8 & 42.4 & 39.6 \\
\hline ASTM D445 & $\begin{array}{r}\text { Kinematic viscosity @ } \\
40^{\circ} \mathrm{C}(\mathrm{cST})\end{array}$ & 2.663 & 2.264 & 2.639 & 2.325 & 2.844 & 2.613 & 2.183 & 2.476 \\
\hline \multirow{3}{*}{ ASTM D5291 } & Elemental Analysis (wt $\%$ ) & & & & & & & & \\
\hline & Carbon & 86.90 & 85.73 & 86.19 & 86.46 & 86.94 & 86.86 & 85.66 & 83.8 \\
\hline & Hydrogen & 12.83 & 14.13 & 13.19 & 13.19 & 12.77 & 13.01 & 13.97 & 13.9 \\
\hline ASTM D4629 & Nitrogen (ppm) & 83.6 & 10.3 & 474.4 & 143.0 & 176.5 & 116.2 & 32.0 & 22.2 \\
\hline \multirow{4}{*}{ ASTM D5186 } & Diesel Aromatics by SFC, wt\% & & & & & & & & \\
\hline & Total Aromatics (\%wt) & 34.6 & 12.9 & 10.2 & 30.5 & 32.7 & 29.3 & 14.7 & 14.8 \\
\hline & Mono Aromatics (\%wt) & 25.4 & 10.8 & 8.0 & 25.6 & 21.0 & 19.4 & 12.0 & 12.1 \\
\hline & Polynuclear Aromatics (\%wt) & 9.2 & 2.0 & 2.2 & 5.0 & 11.7 & 9.9 & 2.7 & 2.7 \\
\hline ASTM D613 & Cetane Number & 46.0 & 63.6 & 44.1 & 49.0 & 46.6 & 48.1 & 61.7 & 57.1 \\
\hline ASTM D93 & Flash point $\left({ }^{\circ} \mathrm{F}\right)$ & 127.0 & 148.0 & 152.0 & 152.0 & 156.0 & 154.0 & 154.0 & 156.0 \\
\hline \multirow{18}{*}{ ASTM D86 } & Distillation, ${ }^{\circ} \mathrm{F}$ & & & & & & & & \\
\hline & $\mathrm{IBP}$ & 323.1 & 345.1 & 363.2 & 335.4 & 328.6 & 343.4 & 346.5 & 350.3 \\
\hline & $5 \%$ & 400.9 & 371.7 & 374.8 & 368.7 & 400.7 & 385.0 & 369.6 & 371.7 \\
\hline & $10 \%$ & 423.1 & 381.4 & 385.7 & 382.2 & 424.8 & 409.9 & 380.4 & 386.8 \\
\hline & $15 \%$ & 438.5 & 394.0 & 397.7 & 395.4 & 440.8 & 424.6 & 389.2 & 399.9 \\
\hline & $20 \%$ & 451.5 & 405.0 & 408.8 & 408.1 & 454.3 & 438.5 & 398.8 & 414.4 \\
\hline & $30 \%$ & 473.1 & 428.5 & 432.1 & 436.1 & 479.2 & 463.0 & 422.0 & 446.5 \\
\hline & $40 \%$ & 492.6 & 454.8 & 457.5 & 462.4 & 500.0 & 486.7 & 449.6 & 484.7 \\
\hline & $50 \%$ & 509.5 & 482.7 & 484.9 & 488.5 & 519.0 & 507.0 & 478.3 & 522.6 \\
\hline & $60 \%$ & 527.7 & 512.0 & 513.9 & 515.4 & 537.3 & 526.8 & 507.2 & 556.6 \\
\hline & $70 \%$ & 547.3 & 543.0 & 545.8 & 544.6 & 556.4 & 547.7 & 536.1 & 583.7 \\
\hline & $80 \%$ & 568.9 & 571.8 & 579.7 & 578.6 & 579.9 & 572.1 & 562.7 & 605.1 \\
\hline & $90 \%$ & 601.4 & 600.0 & 620.4 & 621.8 & 611.0 & 603.7 & 589.0 & 623.1 \\
\hline & $95 \%$ & 627.4 & 618.1 & 648.8 & 655.4 & 635.9 & 630.4 & 607.5 & 635.1 \\
\hline & FBP & 649.1 & 630.4 & 666.3 & 680.8 & 656.0 & 652.5 & 621.7 & 650.1 \\
\hline & Recovered & 98.0 & 97.4 & 97.3 & 97.9 & 98.3 & 98.3 & 97.2 & 98.5 \\
\hline & Loss & 1.2 & 1.4 & 1.1 & 1.2 & 1.3 & 1.1 & 1.3 & 0.5 \\
\hline & Residue & 0.8 & 1.2 & 1.6 & 0.9 & 0.4 & 0.6 & 1.5 & 1.0 \\
\hline
\end{tabular}




\subsection{Fuel Properties}

Most of the important fuel properties that have an influence on engine emissions have been discussed earlier in the literature review chapter. The following section discusses about the differences in the fuel properties and their effect on emissions.

\subsubsection{Cetane Number}

Cetane number is an important property of fuels which influences combustion process and $\mathrm{NO}_{\mathrm{x}}$ emissions. Figure 5-1 shows a comparison of the cetane numbers for the tested fuels with Guttman-1 having highest cetane number of 63.6 and the Shell Bakersfield having lowest cetane number of 44.1. The No.2 diesel fuels cetane number ranged from 44.1 to 49.0 and for the B20 it was 57.1. The average was 52.0 and variation of all fuels was $14.65 \%$. A plot of cetane number versus total aromatic content is attached in Appendix C which represent the correlation between them.

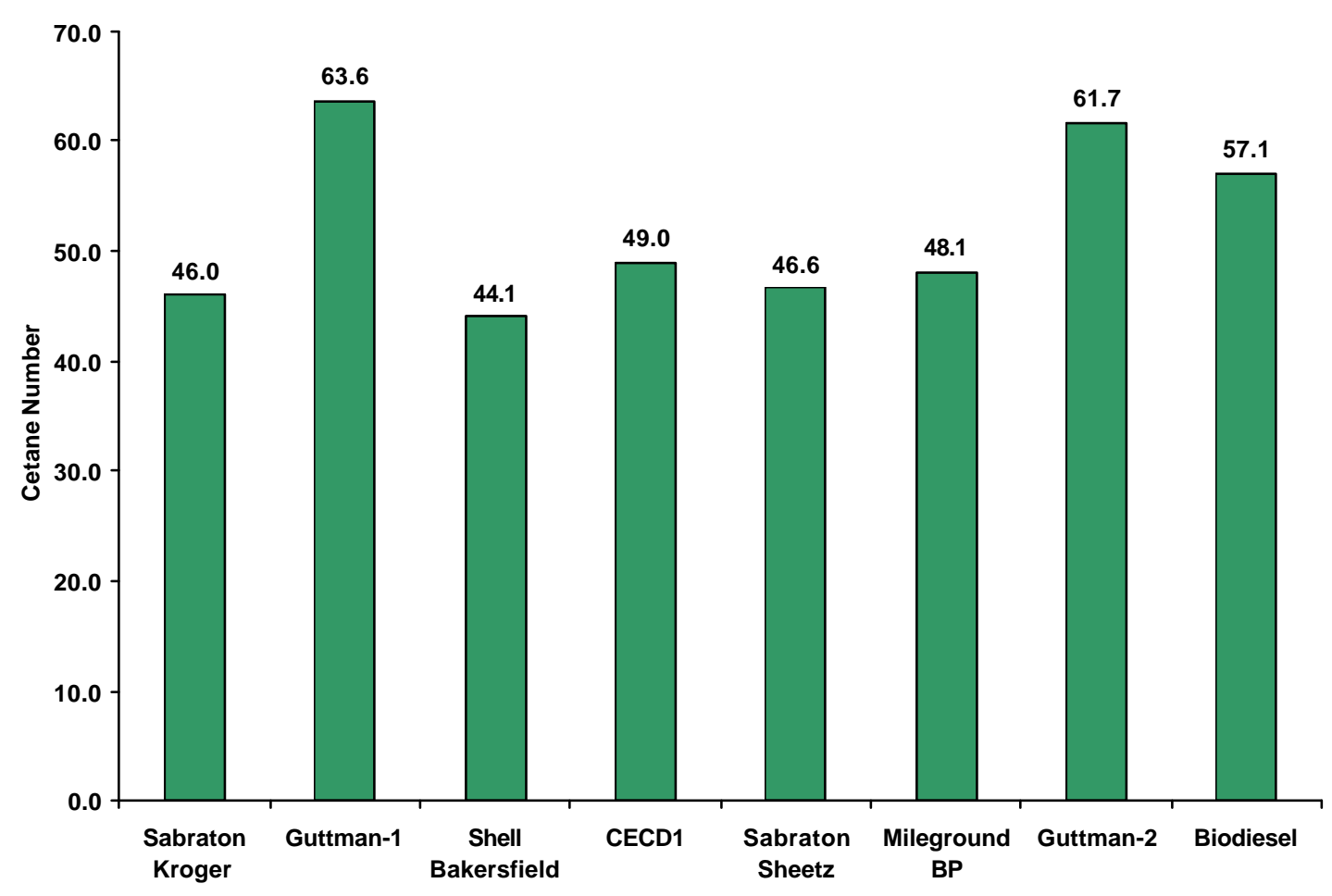

Figure 5-1 Cetane Number of Tested Fuels 


\subsubsection{Aromatics}

A comparison of the btal aromatic content along with polyaromatics and monoaromatics of fuels tested is displayed in Figure 5-2. The total aromatic content was as high as 34.6 (\% wt) for the Sabraton Kroger and lowest for the Shell Bakersfield fuel of 10.6 (\%wt) with the over all variation of $45.28 \%$. The No.1 diesel fuels had lower total aromatic content when compared to the other fuels. The polynuclear aromatic content ranged between 2 (\%wt) to 12 (\%wt) with No.1 diesel having the lowest polynuclear aromatic content. The ratio of polynuclear aromatics to total aromatics varied between 0.15 to 0.35 .

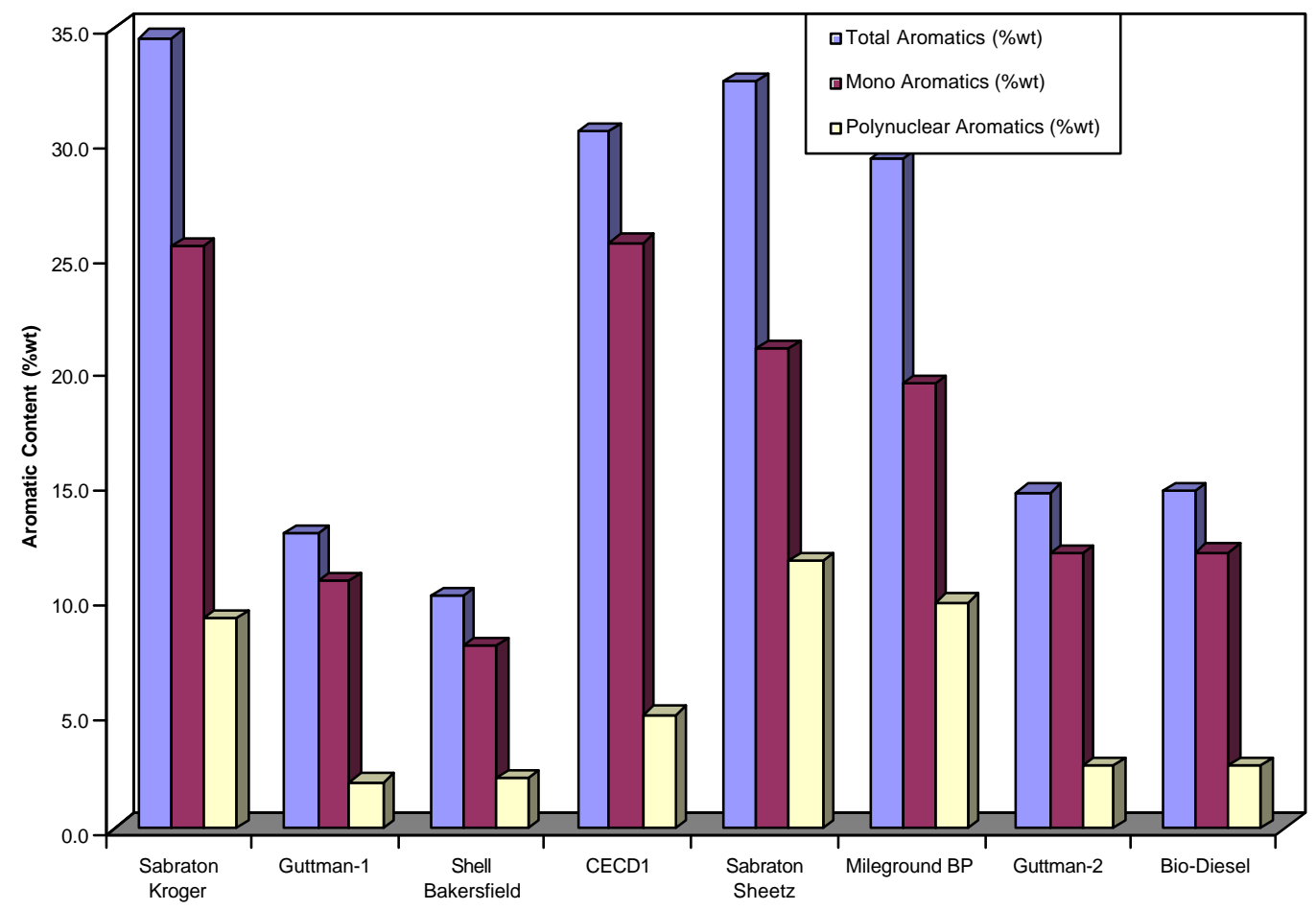

Figure 5-2 Aromatic Contents of Tested Fuels

\subsubsection{Specific Gravity}

Generally, lower specific gravity fuel results in high paraffin content, leading to increase in cetane number [26]. This observation can made from graphical presentations seen in Figure 5-1 and Figure 5-3. The Guttman-1 fuel had the lowest specific gravity of 0.81 and correspondingly high cetane number of 63.3 and the Sabraton Sheetz fuel had a highest 
specific gravity of 0.856 with a low cetane number of 46.6 . The average specific gravity of all the fuels was 0.837 with an over all variation of $2.2 \%$.

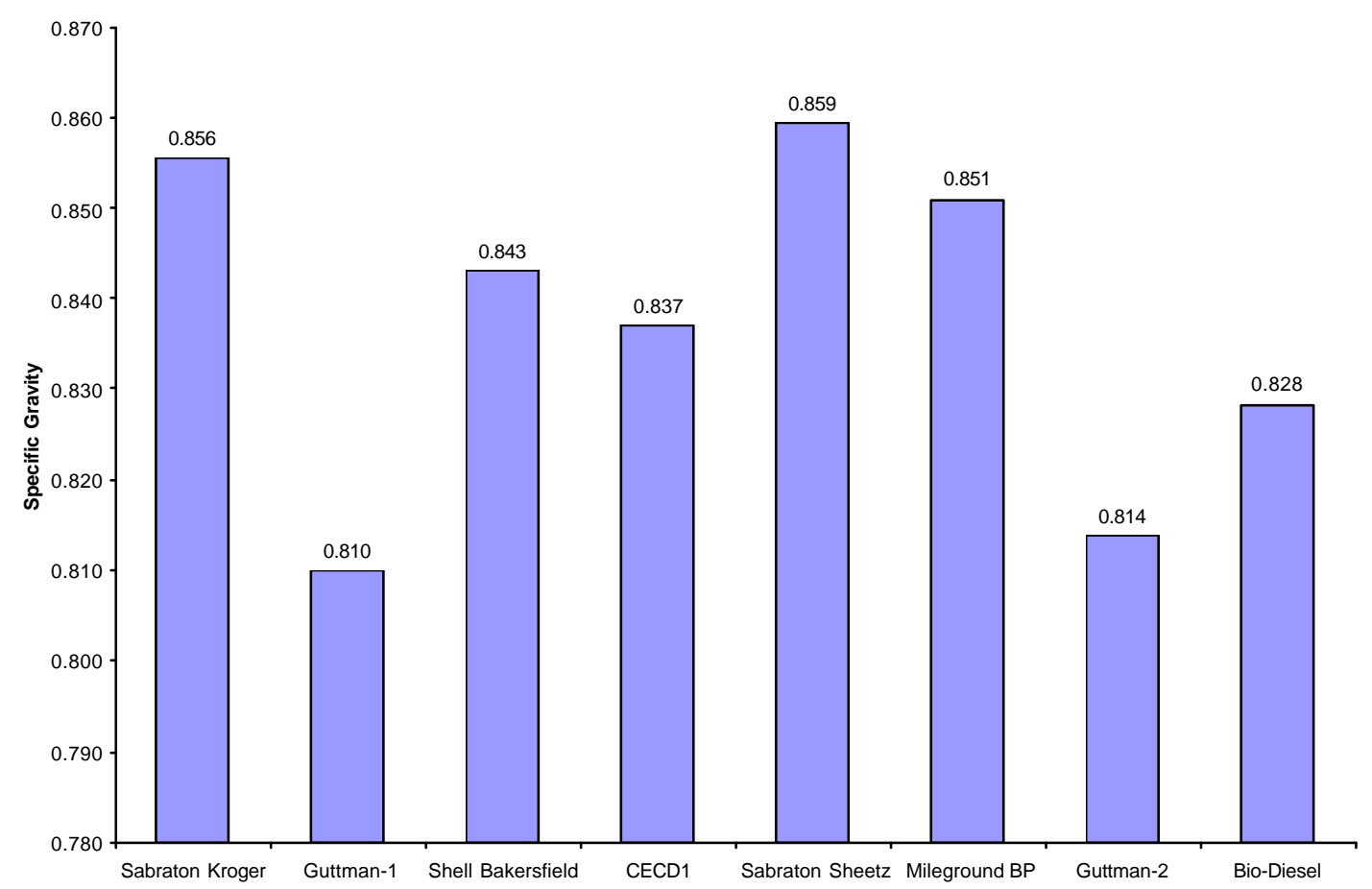

Figure 5-3 Specific Gravity of Tested Fuels

\subsubsection{Sulfur Content}

The sulfur content for the fuels was less than 500ppm which falls under the low sulfur diesel fuels group which can be observed from Figure 5-4. The Shell Bakersfield fuel contained the lowest sulfur content of 166 ppm and Guttmann-1 having the highest of 455 ppm. The average sulfur content was $328.3 \mathrm{ppm}$ with an over all variation of $31.55 \%$. This shows that the sulfur content has a wide range in the fuels tested within regulation limits.

\subsubsection{Volatility}

The distillation temperatures of individual fuels from $5 \%$ to $95 \%$ recovery along with initial and final boiling point temperatures are displayed in Figure 5-5. The minimum and maximum distillation temperature at $90 \%$ recovery for No. 2 diesel fuels is $539.6{ }^{\circ} \mathrm{F}$ and 640.4 ${ }^{\circ} \mathrm{F}$. The fuels tested ranged between $589^{\circ} \mathrm{F}$ and $623.1{ }^{\circ} \mathrm{F}$ at the $90 \%$ recovery temperature. The fuels from California had low temperatures at low distillation rate but had highest $95 \%$ 
distillation recovery temperatures. The Guttman-1 and Guttman-2 fuels showed a different trend with low temperatures at low distillation rate with lower 95\% recovery temperatures where as the remaining fuels showed similar trends to each other.

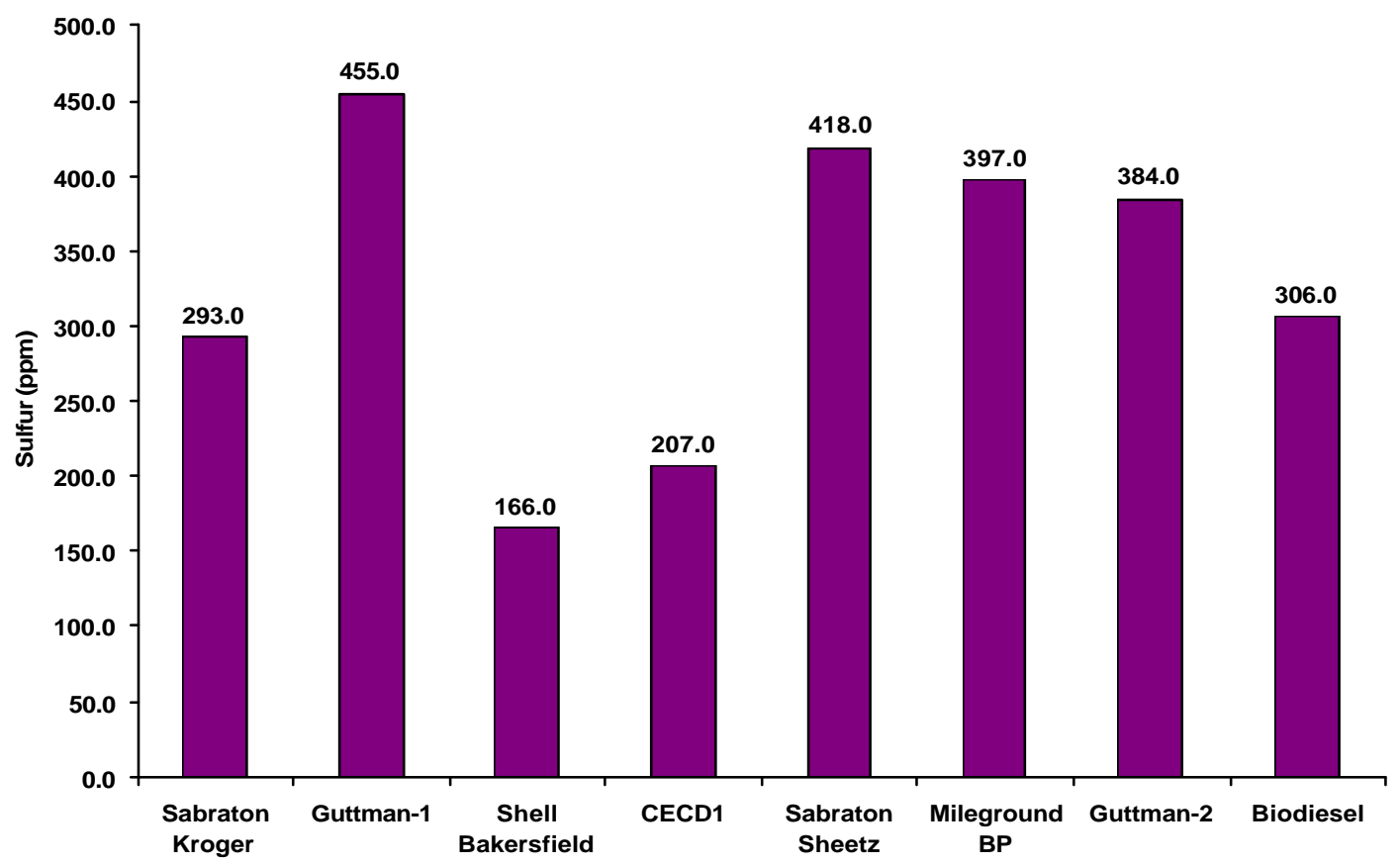

Figure 5-4 Sulfur Content of Tested Fuels

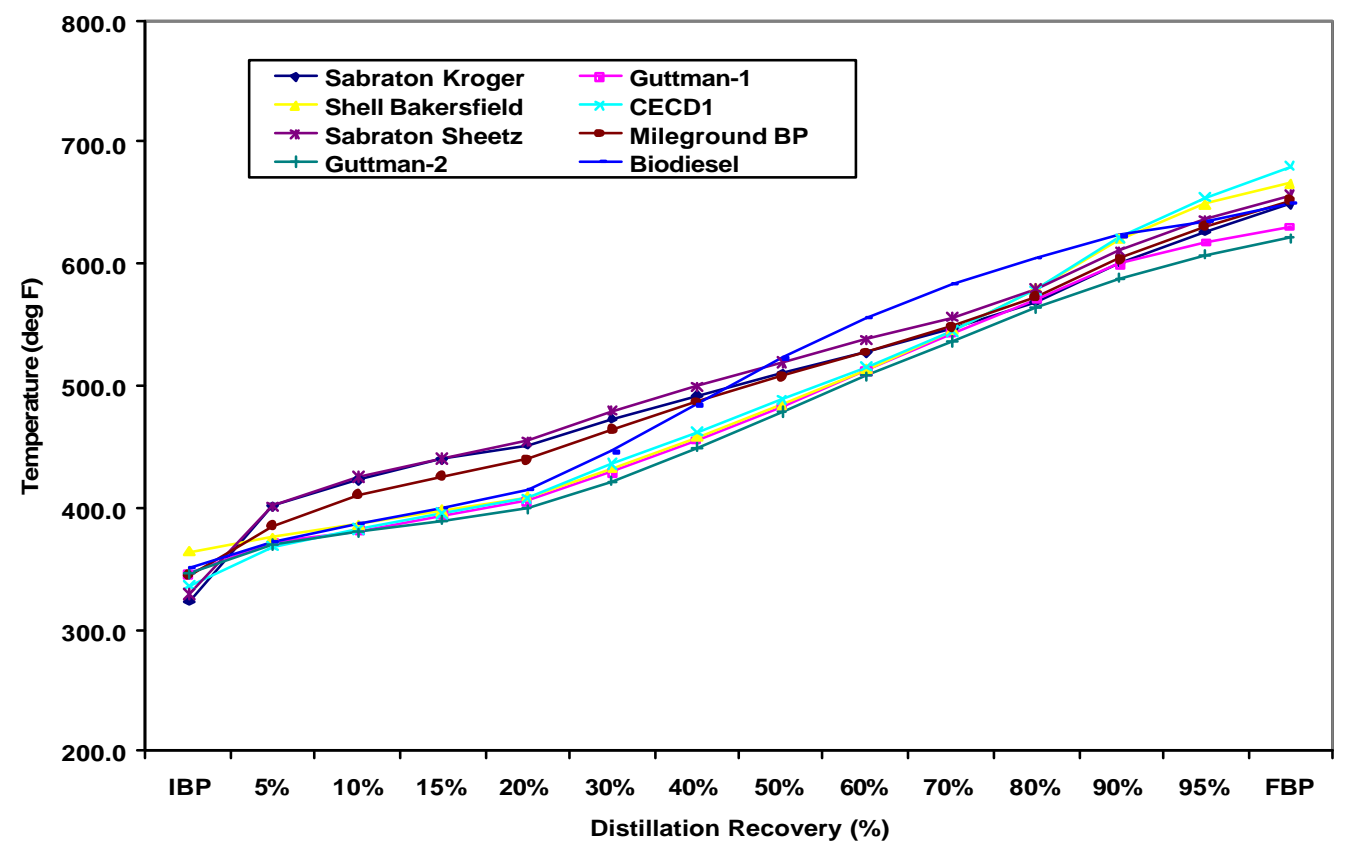

Figure 5-5 Distillation Temperatures of Test Fuels 


\subsection{Fuel Specific Emissions}

Diesel combustion involves physical and chemical processes which are complex in nature including atomization, vaporization, ignition and combustion. The engines response to the changes in fuel property varies with design, control strategy and operating conditions. High NOx formation is associated with high in-cylinder temperatures as a result of high premix burn fraction. HC are normally formed due to over or under mixing of fuel and air, and large size droplets at end of fuel injection. PM originates from organic and inorganic substances accompanied with fuel and air. It mainly consists of carbonaceous matter as a result of heterogeneous combustion process and $\mathrm{CO}$ is a product of incomplete combustion.

The two cycles, FTP and ESC, chosen for discussion emit out different levels of emissions and therefore absolute comparison of emissions and fuel sensitivity cannot be made. However, the data comparison shows the general effect of fuel property on emissions from the two cycles.

The results for the test displaying the regulated emissions $\left(\mathrm{HC}, \mathrm{CO}, \mathrm{CO}_{2}, \mathrm{NO}_{\mathrm{x}}\right.$ and PM), actual work done, brake specific fuel consumption (bsfc) and fuel consumption for both the engines along with variation analysis are shown in Table 5-2 through Table 5-9.

Table 5-2 FTP Results for DDC S60

\begin{tabular}{|l|c|c|c|c|c|c|c|c|}
\hline & $\begin{array}{c}\text { Sabraton } \\
\text { Kroger }\end{array}$ & Guttman-1 & $\begin{array}{c}\text { Shell } \\
\text { Bakersfield }\end{array}$ & CEDC1 & $\begin{array}{c}\text { Sabraton } \\
\text { Sheetz }\end{array}$ & $\begin{array}{c}\text { Mileground } \\
\text { BP }\end{array}$ & Guttman-2 & $\begin{array}{c}\text { Biodiesel } \\
\text { B20 }\end{array}$ \\
\hline HC (g/bhp-hr) & 0.114 & 0.104 & 0.124 & 0.112 & 0.099 & 0.113 & 0.096 & 0.088 \\
\hline Standard Deviation & 0.009 & 0.005 & 0.003 & 0.002 & 0.002 & 0.001 & 0.002 & 0.004 \\
\hline CO (g/bhp-hr) & 2.680 & 2.493 & 3.086 & 2.717 & 2.826 & 2.848 & 2.612 & 2.300 \\
\hline Standard Deviation & 0.301 & 0.008 & 0.037 & 0.046 & 0.091 & 0.039 & 0.034 & 0.023 \\
\hline CO2 (g/bhp-hr) & 520.7 & 517.0 & 521.9 & 527.0 & 532.8 & 527.3 & 531.3 & 530.6 \\
\hline Standard Deviation & 7.472 & 0.311 & 2.022 & 1.142 & 0.650 & 1.060 & 6.834 & 1.182 \\
\hline NOx (g/bhp-hr) & 4.745 & 4.469 & 4.896 & 4.798 & 5.203 & 5.125 & 4.590 & 4.789 \\
\hline Standard Deviation & 0.485 & 0.006 & 0.027 & 0.020 & 0.036 & 0.015 & 0.008 & 0.019 \\
\hline PM (g/bhp-hr) & 0.219 & 0.208 & 0.235 & 0.226 & 0.236 & 0.225 & 0.226 & 0.172 \\
\hline Standard Deviation & 0.008 & 0.005 & 0.004 & 0.003 & 0.008 & 0.005 & 0.002 & 0.002 \\
\hline Actual work (bhp-hr) & 23.73 & 23.20 & 24.51 & 24.28 & 24.90 & 24.57 & 23.41 & 23.59 \\
\hline Standard Deviation & 0.950 & 0.029 & 0.136 & 0.240 & 0.025 & 0.010 & 0.021 & 0.055 \\
\hline BSFC (b/bhp-hr) & 0.383 & 0.379 & 0.387 & 0.420 & 0.389 & 0.389 & 0.380 & 0.390 \\
\hline Standard Deviation & 0.007 & 0.000 & 0.001 & 0.035 & 0.001 & 0.002 & 0.001 & 0.001 \\
\hline Fuel consumption (lb) & 9.083 & 8.786 & 9.477 & 10.184 & 9.678 & 9.566 & 8.895 & 9.191 \\
\hline Standard Deviation & 0.531 & 0.014 & 0.046 & 0.745 & 0.026 & 0.035 & 0.011 & 0.002 \\
\hline
\end{tabular}


Table 5-2 displays the FTP data obtained from the older engine (1992, DDC S60) which shows the average values of three hot starts on each fuel. Table 5-3 displays the variation analysis showing the average emissions for all the fuels, one standard deviation, coefficient of variation $(\mathrm{COV})$ and min-max percentage difference. The individual run data for the FTP cycles is attached in Appendix C.

Table 5-3 Variation Analysis of FTP Results for DDC S60

\begin{tabular}{|c|c|c|c|c|}
\hline \multicolumn{5}{|c|}{$\mathrm{FP}$} \\
\hline & Average & $\begin{array}{l}\text { Standard } \\
\text { Deviation }\end{array}$ & $\begin{array}{l}\text { Coefficient of } \\
\text { Variation }(\%)\end{array}$ & $\begin{array}{l}\text { Min-Max \% } \\
\text { difference }\end{array}$ \\
\hline HC (glbhp-hrr) & 0.106 & 0.01 & 10.82 & 40.0 \\
\hline CO (g/bhp-hr) & 2.695 & 0.24 & 8.85 & 34.2 \\
\hline CO2 (glbhp-hr) & 526.1 & 5.66 & 1.1 & 3.1 \\
\hline NOx (glohp-hr) & 4.827 & 0.25 & 5.12 & 16.4 \\
\hline PM (gabhp-hri) & 0.218 & 0.02 & 9.47 & 37.2 \\
\hline Actual work (bhp-hri) & 24.02 & 0.62 & 2.58 & 7.3 \\
\hline BSFC (bbohp-hr) & 0.389 & 0.01 & 3.33 & 10.9 \\
\hline Fuel consumption (b) & 9.36 & 0.46 & 4.93 & 15.9 \\
\hline
\end{tabular}

Table 5-4 displays the weighted emissions, work done and brake specific fuel consumption (bsfc) for the ESC on the older engine and the variation analysis is shown in Table 5-4.

Table 5-4 ESC Results for DDC S60

\begin{tabular}{|c|c|c|c|c|c|c|c|c|c|c|c|c|}
\hline \multicolumn{13}{|c|}{ ESC } \\
\hline $\begin{array}{l}\text { Weighted } \\
\text { Emissions }\end{array}$ & \begin{tabular}{|l|} 
Sabraton \\
Kroger
\end{tabular} & Guttman-1 & \begin{tabular}{|c|} 
Shell \\
Bakersfield
\end{tabular} & CEDC1 & $\begin{array}{r}\text { Sabraton } \\
\text { Sheetz }\end{array}$ & $\begin{array}{c}\text { Mileground } \\
\text { BP }\end{array}$ & Guttman-2 & $\begin{array}{c}\text { Biodiesel } \\
\text { B20 }\end{array}$ & Average & $\begin{array}{l}\text { Standard } \\
\text { Deviation }\end{array}$ & \begin{tabular}{|l|} 
Coefficeint of \\
Variation $(\%)$
\end{tabular} & $\begin{array}{l}\text { Min-Max \% } \\
\text { difference }\end{array}$ \\
\hline HC (g/bhp-hr) & 0.048 & 0.046 & 0.053 & 0.049 & 0.043 & 0.048 & 0.050 & 0.048 & 0.05 & 0.003 & 5.93 & 22.7 \\
\hline CO (g/bhp-hr) & 3.207 & 3.070 & 3.415 & 3.043 & 3.142 & 3.175 & 3.008 & 2.742 & 3.10 & 0.192 & 6.20 & 24.6 \\
\hline CO2 (g/bhp-hr) & 472.3 & 461.2 & 465.5 & 467.3 & 473.2 & 469.7 & 469.3 & 471.8 & 4668.78 & 4.029 & 0.86 & 2.6 \\
\hline NOx (g/bhp-hr) & 8.308 & 7.306 & 7.643 & 7.694 & 8.220 & 8.000 & 7.350 & 7.746 & 7.78 & 0.370 & 4.75 & 13.7 \\
\hline PM (g/bhp-hr) & 0.106 & 0.107 & 0.102 & 0.105 & 0.094 & 0.111 & 0.053 & 0.041 & 0.09 & 0.027 & 30.36 & 173.2 \\
\hline $\begin{array}{l}\text { Weighted BhpHr } \\
\text { (g/l/bhp-hr) }\end{array}$ & 4.196 & 3.855 & 4.144 & 4.102 & 4.231 & 4.170 & 3.846 & 3.875 & 4.05 & 0.165 & 4.07 & 10.0 \\
\hline $\begin{array}{l}\text { Weighted BSFC } \\
\text { (g/bhphr) }\end{array}$ & 164.0 & 257.3 & 164.3 & 161.5 & 163.2 & 162.2 & 244.3 & 243.4 & 195.0 & 44.3 & 22.7 & 59.3 \\
\hline
\end{tabular}

Table 5-5 displays the regulated emissions, work done, bsfc and fuel consumption for the on-road cycle data for the older engine. The results obtained from the on-roads cycles are additional data so as to represent influence of fuel properties on emissions. This data is not used for comparison between engines due to different on-road cycles used for testing. 
Table 5-5 On-Road Cycle Results for DDC S60

\begin{tabular}{|c|c|c|c|c|c|c|c|c|c|c|c|c|}
\hline \multicolumn{13}{|c|}{ On-Road cycle } \\
\hline & $\begin{array}{c}\text { Sabraton } \\
\text { Kroger }\end{array}$ & Guttman-1 & $\begin{array}{c}\text { Shell } \\
\text { Bakersfield }\end{array}$ & CEDC1 & $\begin{array}{l}\text { Sabraton } \\
\text { Sheetz }\end{array}$ & $\begin{array}{c}\text { Mileground } \\
\text { BP } \\
\end{array}$ & Guttman-2 & \begin{tabular}{|c} 
Biodiesel \\
B20 \\
\end{tabular} & Average & $\begin{array}{l}\text { Standard } \\
\text { Deviation }\end{array}$ & $\begin{array}{l}\text { Coefficient of } \\
\text { Variation }(\%)\end{array}$ & $\begin{array}{l}\text { Min-Max \% } \\
\text { difference } \\
\end{array}$ \\
\hline HC (g/bhp-hr) & 0.066 & 0.063 & 0.059 & 0.063 & 0.059 & 0.057 & 0.057 & 0.053 & 0.059 & 0.004 & 6.76 & 23.1 \\
\hline CO (g/bhp-hr) & 2.158 & 2.000 & 2.102 & 2.311 & 2.035 & 1.923 & 2.173 & 1.762 & 2.058 & 0.169 & 8.19 & 31.2 \\
\hline CO2 (g/bhp-hr) & 474.1 & 457.0 & 471.1 & 467.0 & 468.9 & 474.4 & 467.7 & 468.6 & 468.6 & 5.5 & 1.2 & 3.8 \\
\hline NOx (g/bhp-hr) & 6.193 & 5.581 & 6.033 & 5.744 & 5.900 & 6.233 & 5.561 & 5.835 & 5.885 & 0.256 & 4.35 & 12.1 \\
\hline PM (g/bhp-hr) & 0.137 & 0.134 & 0.139 & 0.149 & 0.131 & 0.136 & 0.148 & 0.104 & 0.135 & 0.014 & 10.51 & 43.9 \\
\hline $\begin{array}{l}\text { Actual work } \\
\text { (bhp-hr) }\end{array}$ & 114.9 & 110.6 & 114.5 & 114.2 & 113.7 & 115.5 & 111.3 & 111.8 & 113.3 & 1.839 & 1.62 & 4.4 \\
\hline $\begin{array}{l}\text { BSFC } \\
\text { (lb/bhp-hrr) }\end{array}$ & 0.352 & 0.358 & 0.352 & 0.350 & 0.351 & 0.351 & 0.341 & 0.348 & 0.350 & 0.005 & 1.35 & 5.0 \\
\hline $\begin{array}{l}\text { Fuel } \\
\text { consumptionn } \\
\text { (lbs) }\end{array}$ & 40.44 & 39.59 & 40.32 & 39.93 & 39.85 & 40.60 & 37.94 & 38.92 & 39.70 & 0.89 & 2.24 & 7.0 \\
\hline
\end{tabular}

Table 5-6 through Table 5-9 displays the results of regulated emissions similar to the DDC, for the FTP, ESC and on-road cycles for the 2004, Cummins ISM 370 engine (modern engine).

Table 5-6 FTP Results for Cummins ISM 370

\begin{tabular}{|l|c|c|c|c|c|c|c|c|}
\hline & $\begin{array}{c}\text { Sabraton } \\
\text { Kroger }\end{array}$ & Guttman-1 & $\begin{array}{c}\text { Shell } \\
\text { Bakersfield }\end{array}$ & CEDC1 & $\begin{array}{c}\text { Sabraton } \\
\text { Sheetz }\end{array}$ & $\begin{array}{c}\text { Mileground } \\
\text { BP }\end{array}$ & Guttman-2 & $\begin{array}{c}\text { Biodiesel } \\
\text { B20 }\end{array}$ \\
\hline HC (g/bhp-hr) & 0.184 & 0.199 & 0.201 & 0.188 & 0.181 & 0.190 & 0.199 & 0.166 \\
\hline Standard Deviation & 0.002 & 0.004 & 0.002 & 0.005 & 0.002 & 0.001 & 0.003 & 0.001 \\
\hline CO (g/bhp-hr) & 0.606 & 0.540 & 0.621 & 0.548 & 0.574 & 0.571 & 0.551 & 0.524 \\
\hline Standard Deviation & 0.011 & 0.008 & 0.004 & 0.006 & 0.012 & 0.006 & 0.006 & 0.001 \\
\hline CO2 (g/bhp-hr) & 582.8 & 571.3 & 572.2 & 574.3 & 582.4 & 578.3 & 577.8 & 575.0 \\
\hline Standard Deviation & 0.562 & 0.574 & 1.144 & 1.195 & 0.653 & 0.749 & 7.293 & 1.079 \\
\hline NOx (g/bhp-hr) & 2.296 & 2.101 & 2.161 & 2.149 & 2.290 & 2.259 & 2.102 & 2.223 \\
\hline Standard Deviation & 0.002 & 0.008 & 0.003 & 0.008 & 0.004 & 0.004 & 0.008 & 0.006 \\
\hline PM (g/bhp-hr) & 0.070 & 0.061 & 0.060 & 0.060 & 0.074 & 0.072 & 0.062 & 0.045 \\
\hline Standard Deviation & 0.001 & 0.000 & 0.002 & 0.002 & 0.000 & 0.001 & 0.000 & 0.002 \\
\hline Actual work (bhp-hr) & 25.92 & 24.55 & 25.53 & 25.25 & 25.98 & 25.72 & 24.51 & 24.38 \\
\hline Standard Deviation & 0.000 & 0.015 & 0.015 & 0.012 & 0.010 & 0.012 & 0.006 & 0.029 \\
\hline BSFC (lb/bhp-hr) & 0.413 & 0.412 & 0.411 & 0.416 & 0.415 & 0.414 & 0.413 & 0.426 \\
\hline Standard Deviation & 0.000 & 0.000 & 0.000 & 0.001 & 0.001 & 0.002 & 0.000 & 0.001 \\
\hline Fuel consumption (lb) & 10.71 & 10.11 & 10.50 & 10.50 & 10.77 & 10.64 & 10.12 & 10.39 \\
\hline Standard Deviation & 0.009 & 0.009 & 0.004 & 0.025 & 0.020 & 0.041 & 0.001 & 0.043 \\
\hline
\end{tabular}


Table 5-7 Variation Analysis of FTP Results for Cummins ISM 370

\begin{tabular}{|l|c|c|c|c|}
\hline \multicolumn{5}{|c|}{ FTP } \\
\hline & Average & $\begin{array}{c}\text { Standard } \\
\text { Deviation }\end{array}$ & $\begin{array}{c}\text { Coefficient of } \\
\text { Variation (\%) }\end{array}$ & $\begin{array}{c}\text { Min - Max \% } \\
\text { difference }\end{array}$ \\
\hline HC (g/bhp-hr) & 0.188 & 0.01 & 6.27 & 21.2 \\
\hline CO (g/bhp-hr) & 0.567 & 0.03 & 5.84 & 18.6 \\
\hline CO2 (g/bhp-hr) & 576.8 & 4.35 & 0.75 & 2.0 \\
\hline NOx (g/bhp-hr) & 2.198 & 0.08 & 3.63 & 9.2 \\
\hline PM (g/bhp-hr) & 0.063 & 0.01 & 14.58 & 63.2 \\
\hline Actual work (bhp-hr) & 25.23 & 0.66 & 2.63 & 6.6 \\
\hline BSFC (lb/bhp-hr) & 0.415 & 0.00 & 1.14 & 3.6 \\
\hline Fuel consumption (lb) & 10.47 & 0.25 & 2.39 & 6.5 \\
\hline
\end{tabular}

Table 5-8 ESC Results for Cummins ISM 370

\begin{tabular}{|c|c|c|c|c|c|c|c|c|c|c|c|}
\hline \multicolumn{12}{|c|}{ ESC } \\
\hline Weighted Emissions & $\begin{array}{c}\text { Sabraton } \\
\text { Kroger }\end{array}$ & Guttman-1 & CEDC1 & $\begin{array}{c}\text { Sabraton } \\
\text { Sheetz } \\
\end{array}$ & $\begin{array}{l}\text { Mileground } \\
\text { BP }\end{array}$ & Guttman-2 & $\begin{array}{c}\text { Biodiesel } \\
\text { B20 }\end{array}$ & Average & $\begin{array}{l}\text { Standard } \\
\text { Deviation }\end{array}$ & $\begin{array}{l}\text { Coefficeint of } \\
\text { Variation (\%) }\end{array}$ & $\begin{array}{l}\text { Min-Max \% } \\
\text { difference }\end{array}$ \\
\hline HC (g/bhp-hr) & 0.102 & 0.107 & 0.107 & 0.106 & 0.106 & 0.109 & 0.090 & 0.104 & 0.006 & 6.01 & 20.60 \\
\hline CO (g/bhp-hr) & 0.311 & 0.312 & 0.305 & 0.343 & 0.311 & 0.308 & 0.286 & 0.311 & 0.017 & 5.40 & 19.92 \\
\hline CO2 (g/bhp-hr) & 520.1 & 506.7 & 610.9 & 513.4 & 520.8 & 510.7 & 512.1 & 527.833 & 36.984 & 7.01 & 20.56 \\
\hline NOx (g/bhp-hr) & 1.979 & 1.894 & 1.919 & 2.043 & 1.993 & 1.866 & 1.961 & 1.951 & 0.062 & 3.16 & 9.51 \\
\hline PM (g/bhp-hr) & 0.018 & 0.016 & 0.017 & 0.021 & 0.019 & 0.018 & 0.013 & 0.017 & 0.002 & 13.61 & 54.79 \\
\hline $\begin{array}{l}\text { Weighted BhpHr (g/bhp } \\
\text { hr) }\end{array}$ & 4.256 & 4.039 & 4.146 & 4.281 & 4.218 & 4.055 & 4.036 & 4.147 & 0.106 & 2.56 & 6.08 \\
\hline $\begin{array}{l}\text { Weighted BSFC } \\
\text { (g/bhphr) }\end{array}$ & 163.3 & 168.1 & 168.1 & 164.9 & 163.2 & 168.6 & 169.6 & 166.5 & 2.671 & 1.60 & 3.90 \\
\hline
\end{tabular}

Table 5-9 On-Road Cycle Results for Cummins ISM 370

\begin{tabular}{|l|c|c|c|c|c|c|c|c|c|c|c|}
\hline & $\begin{array}{c}\text { Sabraton } \\
\text { Kroger }\end{array}$ & Guttman-1 & CEDC1 & $\begin{array}{c}\text { Sabraton } \\
\text { Sheetz }\end{array}$ & $\begin{array}{c}\text { Mileground } \\
\text { BP }\end{array}$ & Guttman-2 & $\begin{array}{c}\text { Biodiesel } \\
\text { B20 }\end{array}$ & Average & $\begin{array}{c}\text { Standard } \\
\text { Deviation }\end{array}$ & $\begin{array}{c}\text { Coefficient of } \\
\text { Variation (\%) }\end{array}$ & $\begin{array}{c}\text { Min-Max \% } \\
\text { difference }\end{array}$ \\
\hline HC (g/bhp-hr) & 0.121 & 0.115 & 0.119 & 0.111 & 0.118 & 0.117 & 0.098 & 0.114 & 0.008 & 6.71 & 22.7 \\
\hline CO (g/bhp-hr) & 0.325 & 0.315 & 0.316 & 0.313 & 0.319 & 0.314 & 0.282 & 0.312 & 0.014 & 4.43 & 15.2 \\
\hline CO2 (g/bhp-hr) & 522.9 & 507.7 & 514.2 & 523.5 & 520.9 & 508.5 & 509.7 & 515.338 & 6.996 & 1.36 & 3.1 \\
\hline NOx (g/bhp-hr) & 2.146 & 1.955 & 2.023 & 2.140 & 2.112 & 1.967 & 2.245 & 2.084 & 0.106 & 5.10 & 14.8 \\
\hline PM (g/bhp-hr) & 0.052 & 0.042 & 0.041 & 0.051 & 0.051 & 0.044 & 0.029 & 0.044 & 0.008 & 18.22 & 78.7 \\
\hline Actual work (bhp-hr) & 49.250 & 49.220 & 49.250 & 49.230 & 49.330 & 49.240 & 49.210 & 49.247 & 0.039 & 0.08 & 0.2 \\
\hline BSFC (lb/bhp-hr) & 0.371 & 0.365 & 0.371 & 0.373 & 0.371 & 0.366 & 0.377 & 0.371 & 0.004 & 1.09 & 3.2 \\
\hline Fuel consumption (lb) & 18.29 & 17.97 & 18.26 & 18.38 & 18.29 & 18.02 & 18.54 & 18.25 & 0.197 & 1.08 & 3.2 \\
\hline
\end{tabular}




\subsubsection{Fuel Specific $\mathrm{HC}$ emissions}

The fuel specific $\mathrm{HC}$ emissions of the two engine emissions are displayed in the same graph to observe the trend for all the fuels as shown in Figure 5-6. The graph displays the data obtained from FTP cycle (along with one standard deviation represented by the bars) and ESC data. The older engine showed a greater minimum to maximum variation of $40 \%$ between fuels when compared to the modern engine which was only $20 \%$. For the FTP data obtained, the lowest $\mathrm{HC}$ emissions of $0.88 \mathrm{~g} / \mathrm{bhp}$-hr for the biodiesel was observed with $0.124 \mathrm{~g} / \mathrm{bhp}$ - $\mathrm{hr}$ being the highest for the shell Bakersfield fuel for the older engine. A similar pattern in the graph was seen in the case of modern engine except for No.1 diesel fuels which showed lower $\mathrm{HC}$ emissions when compared to the older engine. The emissions ranged between 0.166 $\mathrm{g} / \mathrm{bhp}-\mathrm{hr}$ to $0.201 \mathrm{~g} / \mathrm{bhp}-\mathrm{hr}$ for the same fuels respectively. An interesting observation was the $\mathrm{HC}$ emissions were higher in the modern engine when compared to the older engine [27]. The $\mathrm{HC}$ emissions were within the regulatory standards of $1.3 \mathrm{~g} / \mathrm{bhp}-\mathrm{hr}$.

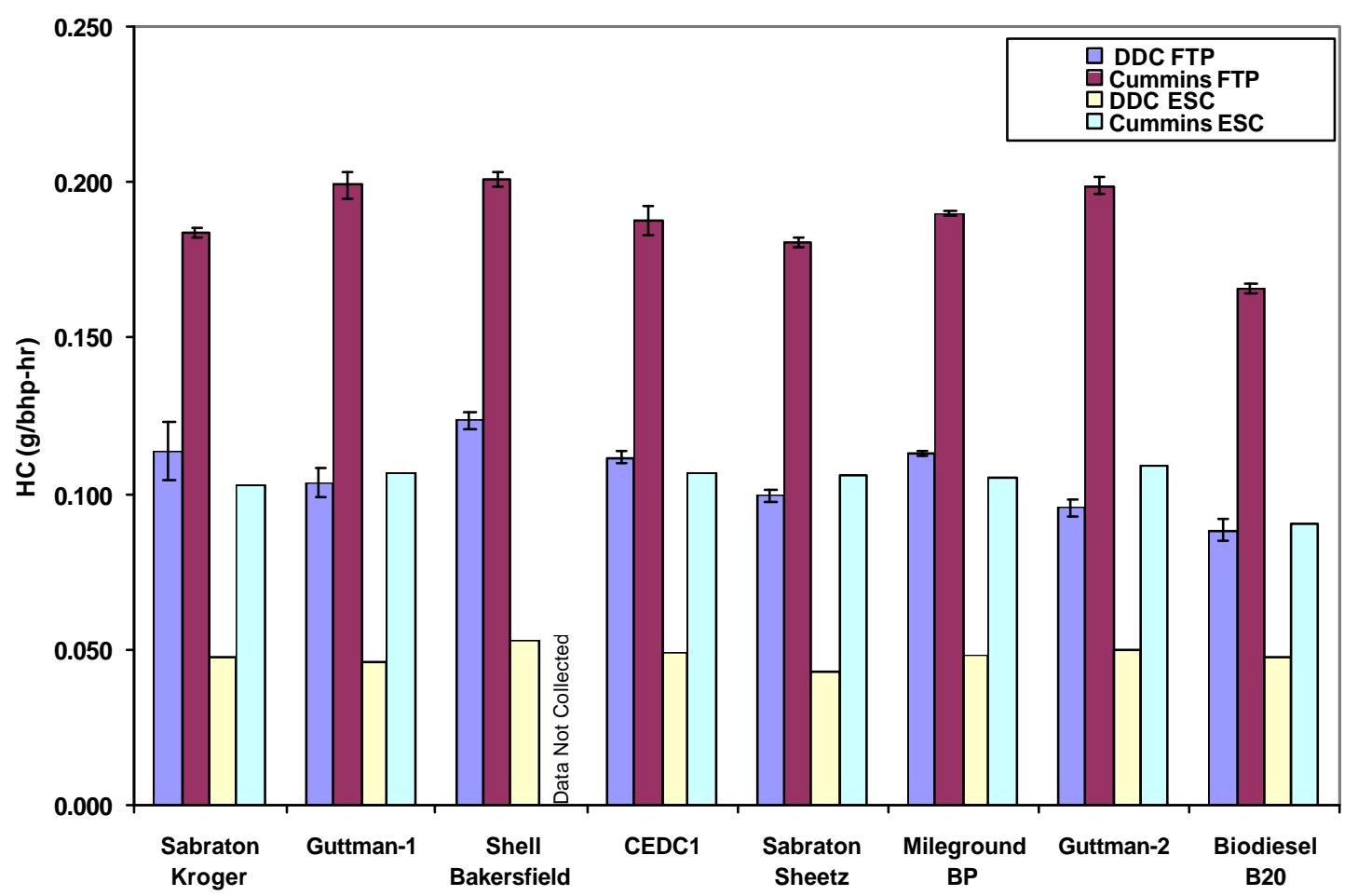

Figure 5-6 Fuel Specific HC Emissions for FTP and ESC Cycles 
For the ESC data in the older engine, the variation between fuels was $23 \%$ with the weighted fuel specific $\mathrm{HC}$ emissions varying from $0.043 \mathrm{~g} / \mathrm{bhp}-\mathrm{hr}$ for Sabraton Sheetz to $0.053 \mathrm{~g} / \mathrm{bhp}-\mathrm{hr}$ for Shell Bakersfield fuel. A variation of $21 \%$ was seen in the modern engine with HC emissions ranging between $0.090 \mathrm{~g} / \mathrm{bhp}$-hr for the B20 to 0.109 for the Guttman-2 fuel. The ESC data for Shell Bakersfield fuel was not taken. The results from ESC cycle showed a similar trend to that seen in FTP cycle.

\subsubsection{Fuel Specific $\mathrm{NO}_{\mathrm{x}}$ Emissions}

When compared to $\mathrm{HC}$ emissions, the $\mathrm{NO}_{\mathrm{x}}$ variations were lesser but significant. A variation of $16 \%$ between the fuels was observed with emissions varying from $4.429 \mathrm{~g} / \mathrm{bhp}-\mathrm{hr}$ for Guttman-1 to 5.203g/bhp-hr for Sabraton Sheetz for the older engine, as seen in Figure 5-7. A lesser variation of $9 \%$ was seen in the modern engine with $\mathrm{NO}_{\mathrm{x}}$ emissions varying between $2.101 \mathrm{~g} / \mathrm{bhp}-\mathrm{hr}$ for Guttman-1 and $2.296 \mathrm{for} \mathrm{g} / \mathrm{bhp}-\mathrm{hr}$ Sabraton Kroger as seen in Figure 5-7. The emissions were generally within the regulatory standards for both the engines.

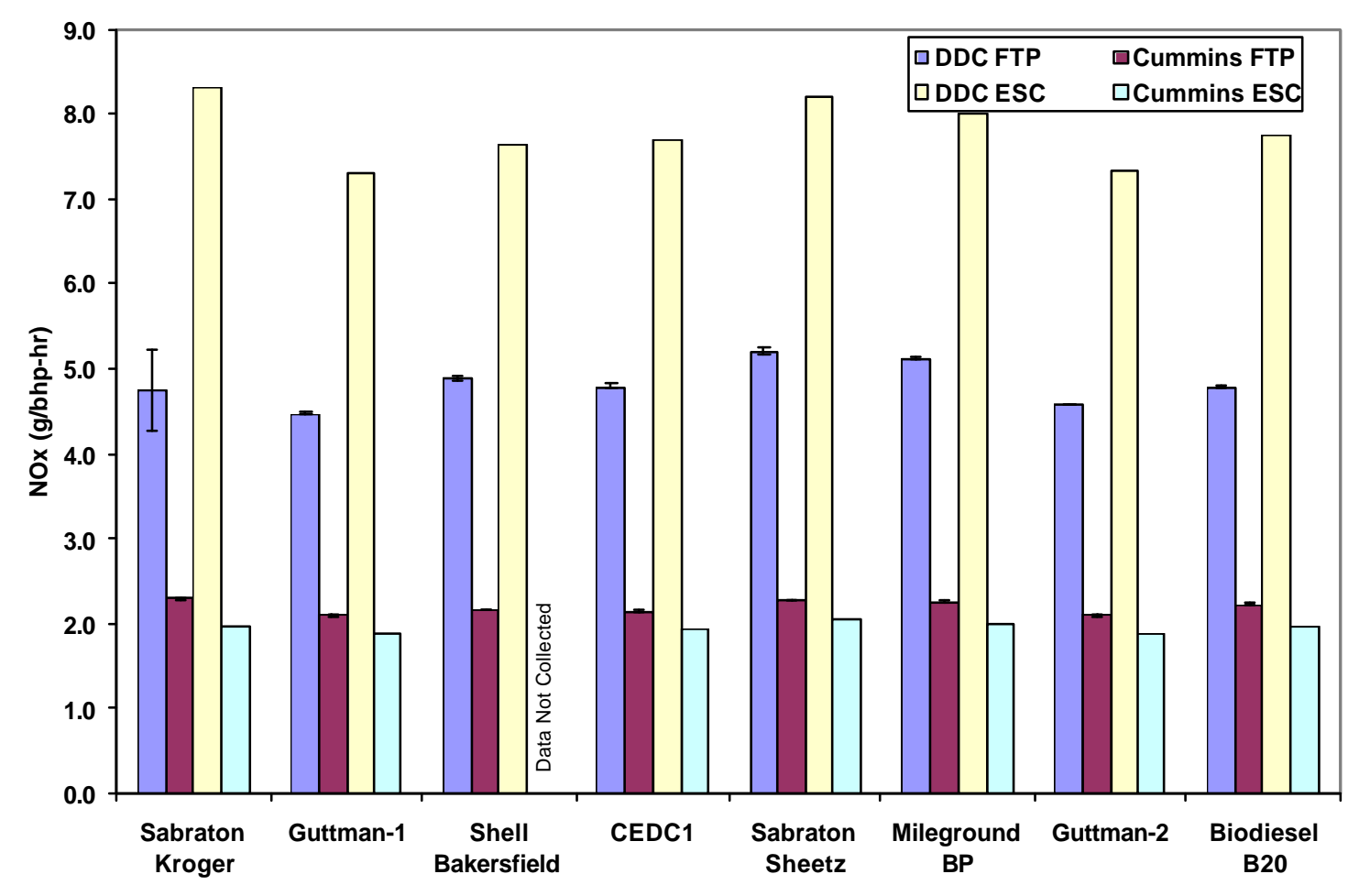

Figure 5-7 Fuel Specific $\mathrm{NO}_{\mathrm{x}}$ Emissions for FTP and ESC Cycles 
The variations for the ESC data were even smaller when compared to the FTP. The older engine showed a variation of $14 \%$ between fuels ranging between $7.306 \mathrm{~g} / \mathrm{bhp}$ - $\mathrm{hr}$ for the Guttman-1 to $8.308 \mathrm{~g} / \mathrm{bhp}$-hr for the Sabraton Kroger fuel. The modern engine showed a similar variation of $9 \%$ when compared to the older engine with emissions ranging between $1.866 \mathrm{~g} / \mathrm{bhp}-\mathrm{hr}$ for the Guttman-2 to $2.043 \mathrm{~g} / \mathrm{bhp}$-hr for the Sabraton Sheetz fuel. It is noted that the older engine technology exhibited significantly higher NOx emissions value (approximately 1.8 times the certification limit) compared to the newer technology. This higher NOx for the old engine was the motivation of the Consent Decrees.

\subsubsection{Fuel Specific PM Emissions}

When compared to $\mathrm{NO}_{\mathrm{x}}$ variations, $\mathrm{PM}$ variations were far more significant with $37 \%$ between fuels on the older engine and PM emissions ranged between $0.172 \mathrm{~g} / \mathrm{bhp}$-hr for the B20 to $0.236 \mathrm{~g} / \mathrm{bhp}$-hr for Sabraton Sheetz as seen in Figure 5-8. The modern engine showed a better response to the fuel property changes with a variation of $63 \%$ between fuels. The PM emissions ranged between $0.045 \mathrm{~g} / \mathrm{bhp}$ - $\mathrm{hr}$ for the B20 to $0.074 \mathrm{~g} / \mathrm{bhp}$-hr for and Sabraton Sheetz as seen in Figure 5-8.

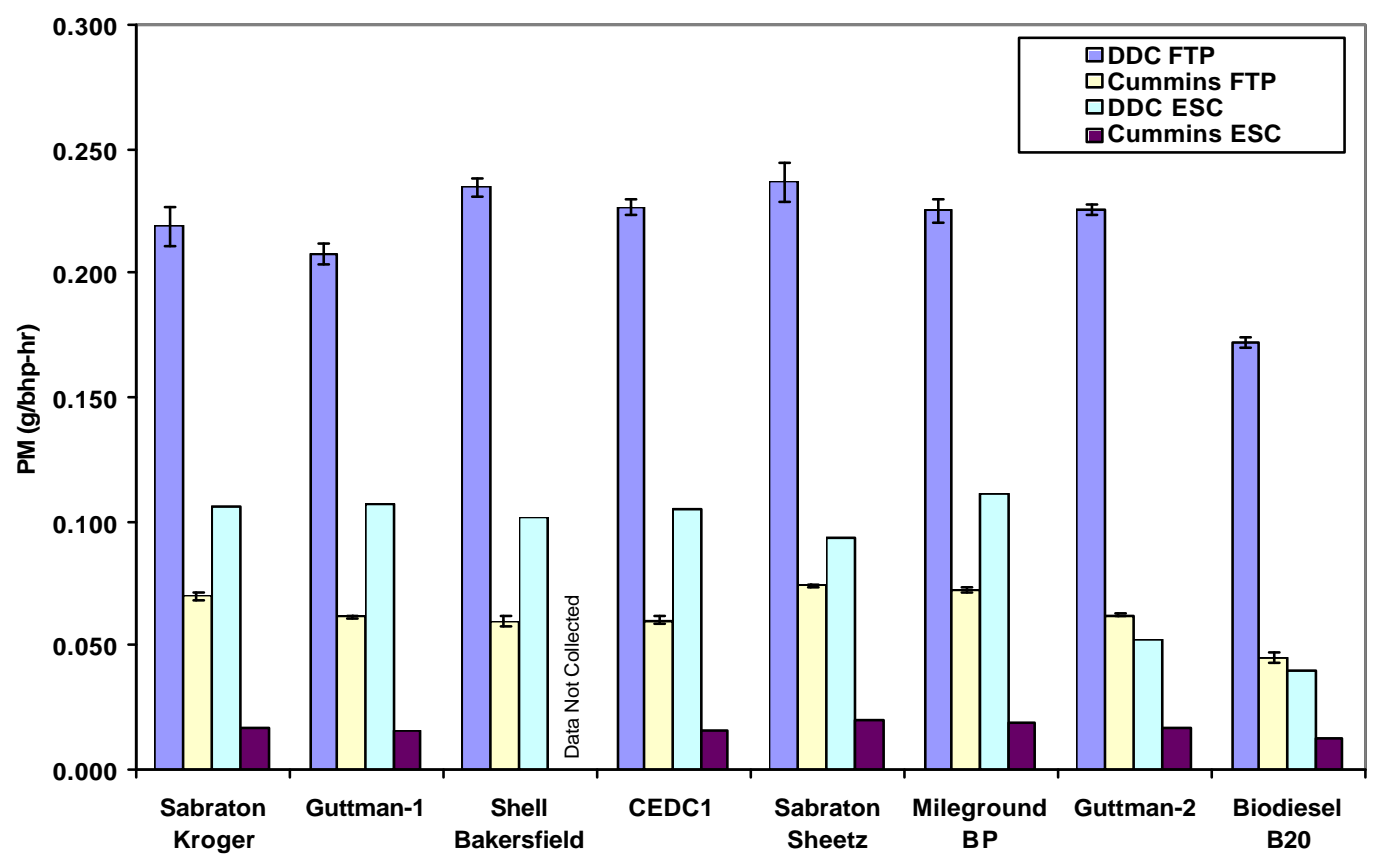

Figure 5-8 Fuel Specific PM Emissions for FTP and ESC Cycles 
Data obtained for the ESC on the older engine did not show the same variation seen in the FTP data. A variation of $14 \%$ was seen with emissions ranging between $0.041 \mathrm{~g} / \mathrm{bhp}$-hr for Sabraton Sheetz to $0.111 \mathrm{~g} / \mathrm{bhp}-\mathrm{hr}$ for Guttman-2 fuel. However the variation was a similar to that of the FTP which was of $55 \%$ and emissions ranging between $0.013 \mathrm{~g} / \mathrm{bhp}$-hr for Sabraton Kroger to 0.021 for Guttman- 1 fuel in the modern engine.

\subsubsection{Fuel Specific $\mathrm{CO}$ and $\mathrm{CO}_{2}$ Emissions}

The variations for CO emissions were $34 \%$ for the FTP data ranging between 2.3 g/bhp-hr for the B20 and $3.086 \mathrm{~g} / \mathrm{bhp}-\mathrm{hr}$ for Shell Bakersfield. A lower variation of $24 \%$ for the ESC data was seen in the older engine with emissions ranging between $2.742 \mathrm{~g} / \mathrm{bhp}$ - hr and $3.415 \mathrm{~g} / \mathrm{bhp}-\mathrm{hr}$. The $\mathrm{CO}_{2}$ variations were the lowest when compared to other emissions with $3 \%$ for the FTP data ranging from $461.1 \mathrm{~g} / \mathrm{bhp}-\mathrm{hr}$ to $473.2 \mathrm{~g} / \mathrm{bhp}-\mathrm{hr}$. The ESC data showed a similar variation of $4 \%$. The modern engine showed a lower CO variation of $19 \%$ for the FTP and ranging between 0.524 and 0.621 and $19 \%$ for the ESC with a maximum of 0.343 . For the $\mathrm{CO}_{2}$ emissions, the variation was $2 \%$ for FTP cycle and ranging between $582.8 \mathrm{~g} / \mathrm{bhp}-\mathrm{hr}$ and $571.3 \mathrm{~g} / \mathrm{bhp}-\mathrm{hr}$. The ESC data showed a greater variation of $20 \%$ with maximum emissions of $610.9 \mathrm{~g} / \mathrm{bhp}-\mathrm{hr}$. The figures for the $\mathrm{CO}$ and $\mathrm{CO}_{2}$ data are attached in Appendix D.

\subsubsection{Work and Fuel Economy}

Figure 5-9 displays the actual work done and bsfc for all the fuels tested on the FTP cycle for both the engines. The variation in work done for both engines seemed to be the same of $7 \%$ for both the engines however the older engine showed more variation in bsfc of $10 \%$, and lower in that of the modern engine which was only of $3 \%$. For the ESC, variation of work done was $10 \%$ a little more than seen in the FTP for the older engine where as the modern engine showed a closer response to that of the FTP which had a variation of $6 \%$. 


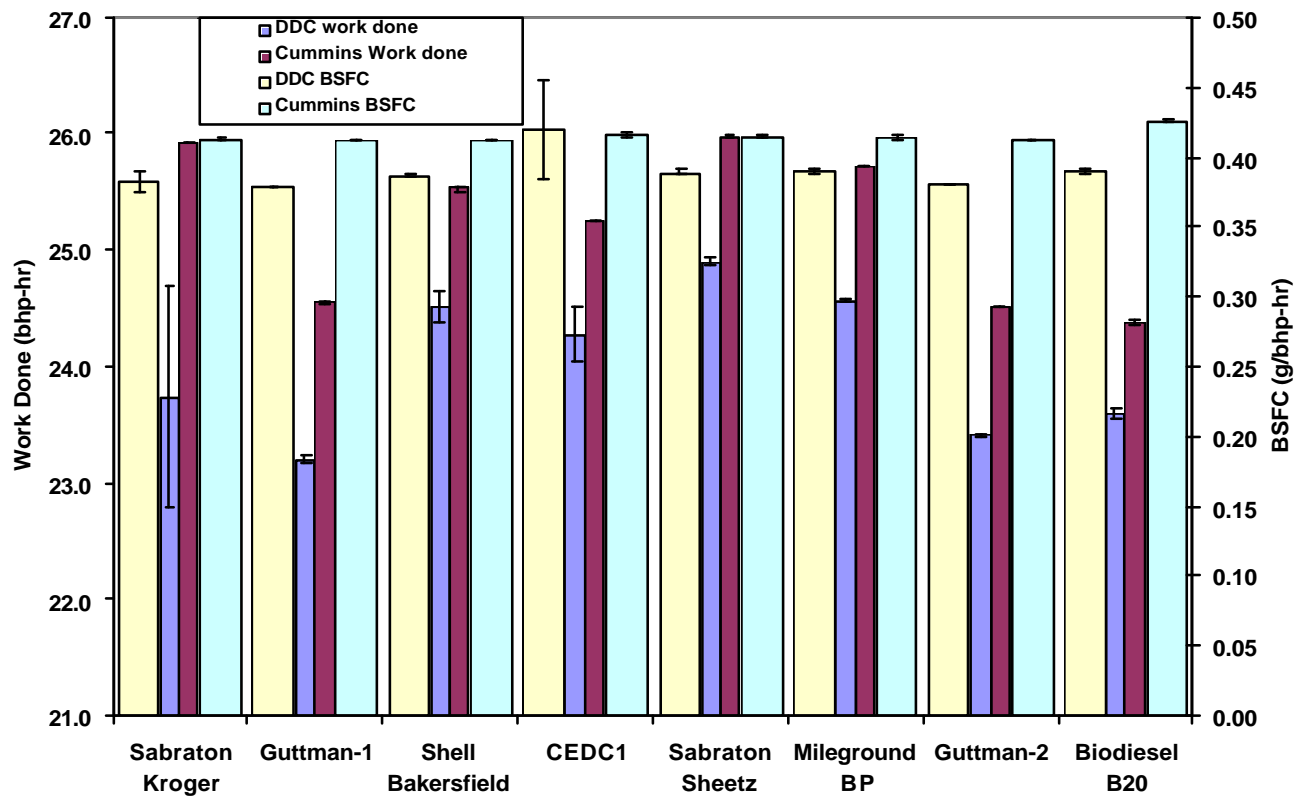

Figure 5-9 Fuel Specific Work Done and BSFC over FTP

\subsection{NOx-PM Trade off}

One of the prominent problems being faced by the engine manufacturers in reducing the emissions is the trade off between $\mathrm{NO}_{\mathrm{x}}$ and PM. The engine manufacturers design control strategies to reduce $\mathrm{NO}_{\mathrm{x}}$ but see an increase in the PM. This was not observed in this study as seen from the plot of PM versus $\mathrm{NO}_{\mathrm{x}}$ in Figure 5-10. The plot illus trates the effect of fuel properties on $\mathrm{NO}_{\mathrm{x}}$ and $\mathrm{PM}$.

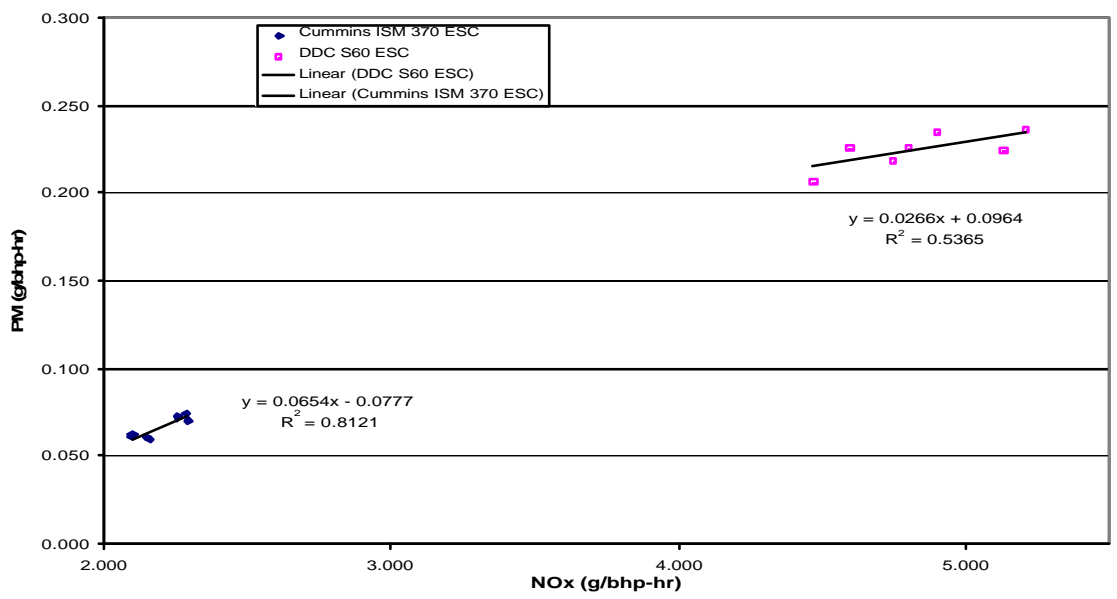

Figure 5-10 $\mathrm{NO}_{\mathrm{x}}$ PM Trade off for FTP 


\subsection{Influence of Fuel Properties on Emissions}

Studies in the past tried to isolate individual fuel properties that affected emissions in HDDE and have found some important properties, which include specific gravity, cetane number, sulfur, aromatics and volatility. The difficulties in identifying properties having an influence on emissions, involve in mainly decoupling the intercorrelation between fuel properties so as to finding out the controlling variable and another aspect is the different control strategies involved in the engines. Some of the previous studies have had success in doing so and some failed. This study focuses on decoupling the intercorrelation between properties and looking into properties that have an influence on emissions of HDDE to correlate with the studies made earlier on effect of fuel properties on emissions.

\subsubsection{Effect of Cetane Number}

Cetane number influences the ignition delay of a fuel. Higher cetane number influences the premixed combustion by reducing the ignition delay thus resulting in lower NOx production [7]. HC emissions have seen beneficial effect in some studies which tend to reduce $\mathrm{HC}$ emissions but some studies have not shown any influence on $\mathrm{HC}$ emissions which is largely to do with the engine design [28].

Figure 5-11 displays the effect of cetane on $\mathrm{HC}, \mathrm{NO}_{\mathrm{x}}$ and $\mathrm{PM}$ emissions tested on older engine over the FTP. The graph shows a linearly fitted line to express the correlation between fuel property and emissions. The $\mathrm{NO}_{\mathrm{x}}$ emissions decreased with an increase in cetane number which correlated to the previous studies made and had a $\mathrm{R}^{2}$ value of 0.5518 . HC emissions also reduced with increase in cetane number and had a $\mathrm{R}^{2}$ value of 0.4542 . Some of the studies made earlier were biased with regards to the effect of cetane on PM. This engine showed little effect of cetane on PM emissions having a $R^{2}$ value of 0.264 . The modern engine showed a lower response to changes in cetane number on emissions as seen in Figure 5-12. 


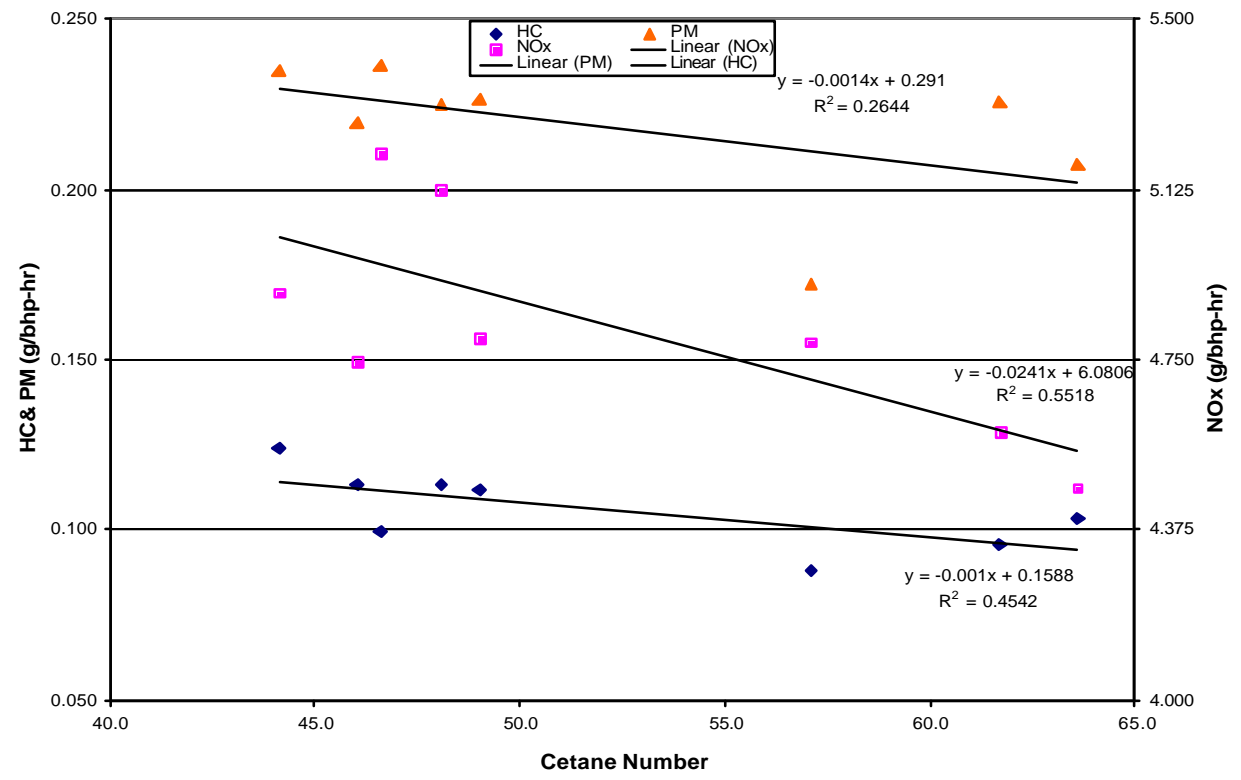

Figure 5-11 Effect of Cetane on DDC S60 over FTP

Effect of cetane on NOx emissions in modern engine showed a lower $\mathrm{R}^{2}$ of 0.4347 which was lower than the older engine. There was a little effect on PM emission, having an $\mathrm{R}^{2}$ of 0.2066 where as the $\mathrm{HC}$ emissions showed a negligible effect with an $\mathrm{R}^{2}$ of 0.0155 . The modern engine showed smaller variations in emissions when compared to the older engine.

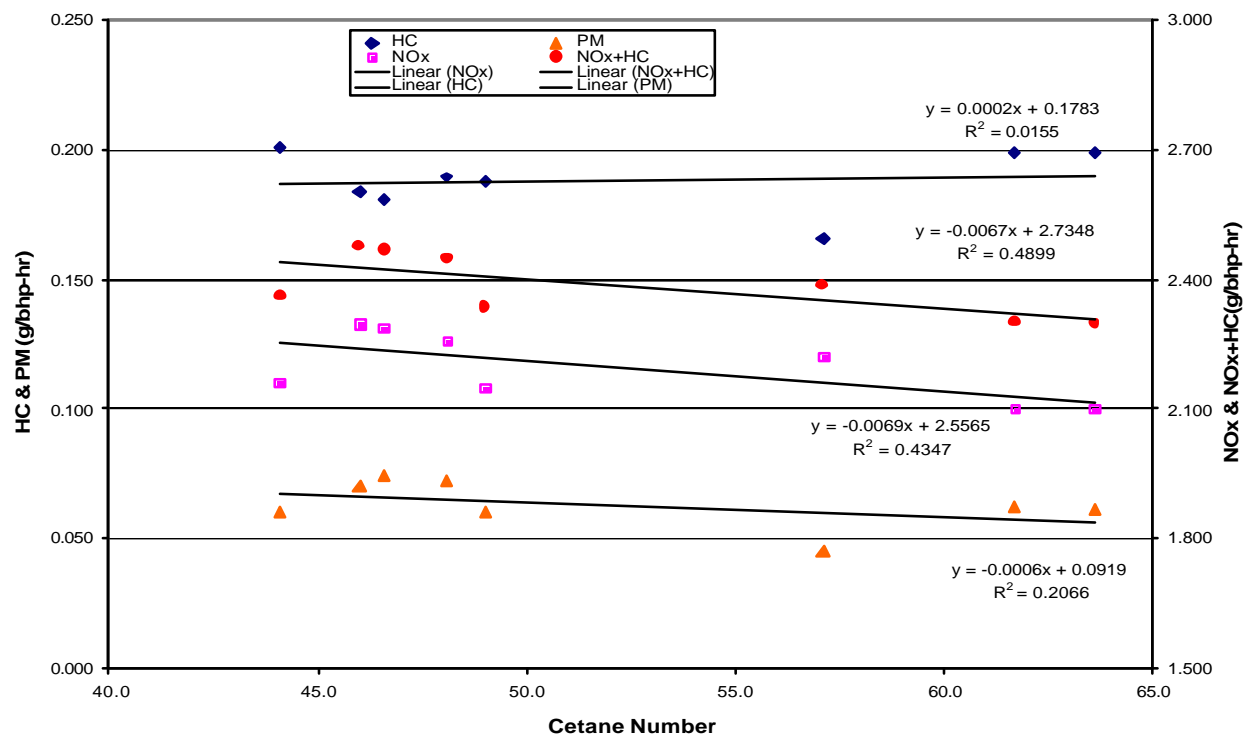

Figure 5-12 Effect of Cetane on Cummins ISMover FTP 


\subsubsection{Effect of Density on Emissions}

Density, another important fuel property is related to volumetric fuel efficiency and power. Effect of density is also seen in the case of injection period which increases with decrease in density due to lower instantaneous mass flow rate of fuel [29]. Some studies have expressed the correlation with aromatics [30]. In regulatory emissions, PM reduces with reduction in density and has a negative effect on $\mathrm{HC}$ emissions eading to higher production of hydrocarbons. Also a reduction in $\mathrm{NO}_{\mathrm{x}}$ is seen as density reduces [31].

Figure 5-13 displays the effect of specific gravity on emissions obtained from the old engine. The $\mathrm{NO}_{\mathrm{x}}$ emissions reduced as the specific gravity reduced and had a good $\mathrm{R}^{2}$ value of 0.702 showing good correlation between the two. However, the specific gravity had insignificant effect on PM and HC emissions having a $\mathrm{R}^{2}$ value of 0.1741 and 0.1931 , respectively.

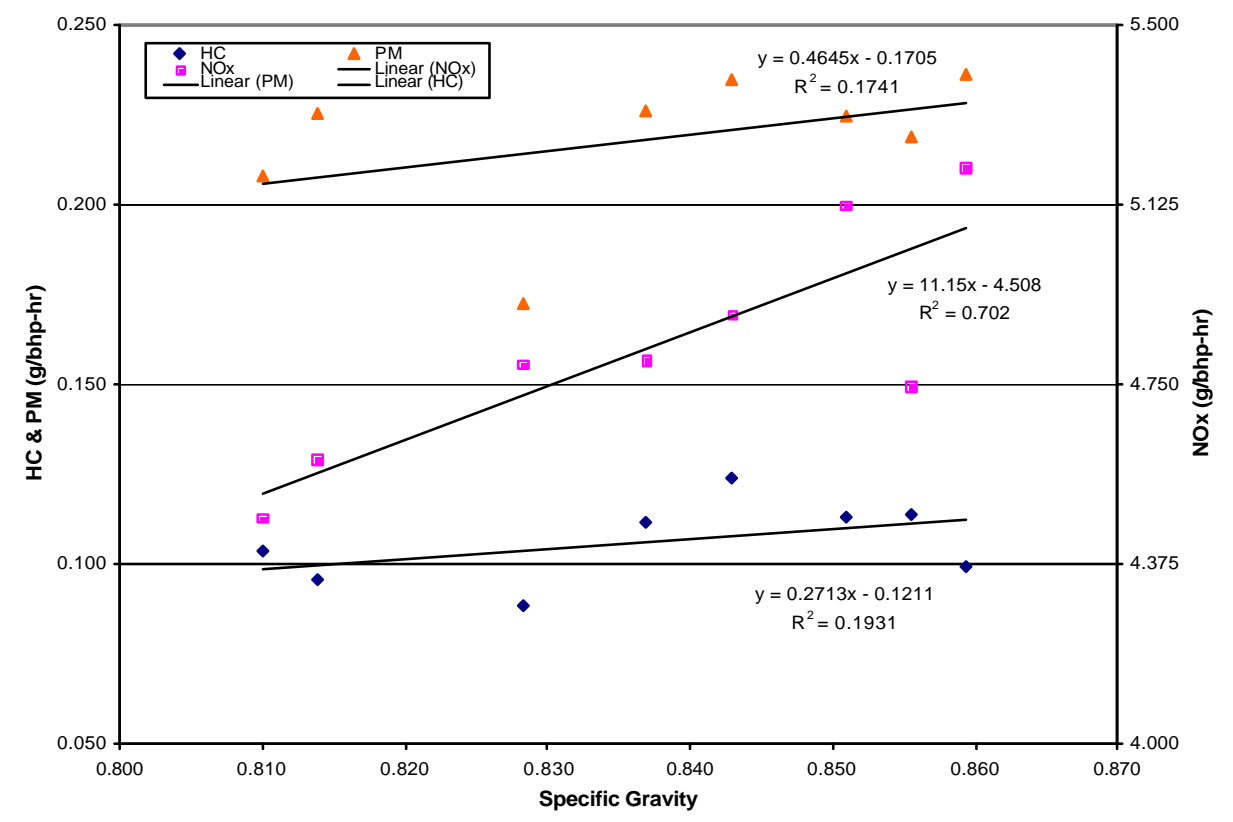

Figure 5-13 Effect of Specific gravity on DDC S60 over FTP

On the modern engine, the NOx emissions had the same effect as seen in the older engine having an $\mathrm{R}^{2}$ value of 0.7713 showing a better response to density changes as seen in Figure 5-13. Density changes were less in the case of HC emission, where as the PM showed a better response to specific gravity change when compared to the older engine. Previous 
studies have shown that PM reduction was seen in older engine but in this study the modern engine was more sensitive to changes in specific gravity.

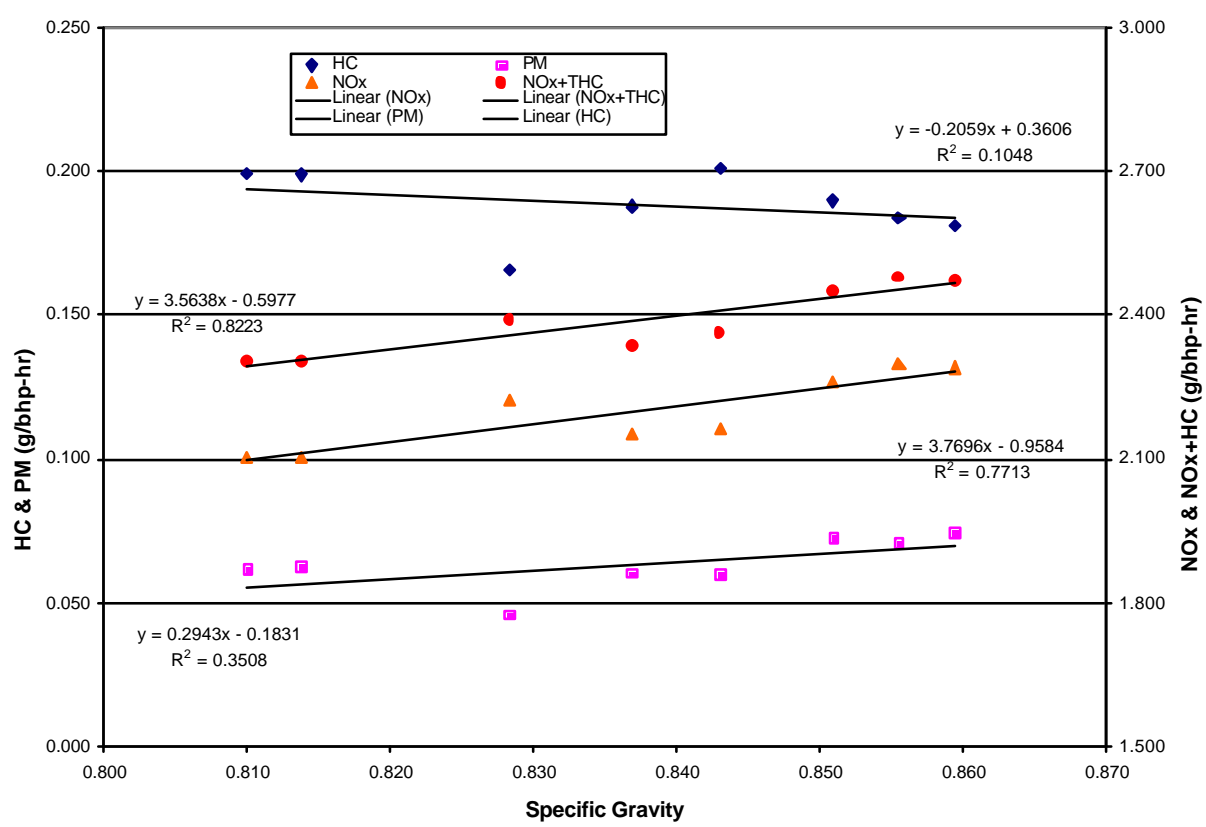

Figure 5-14 Effect of Specific gravity on Cummins ISM over FTP

\subsubsection{Effect of Sulfur on Emissions}

Sulfur content in fuels was considered to influences PM in HHDE, studied at large by many researches [32]. However, the effect of sulfur has no significant effect on engine emissions in this study [33]. Previous studies have discussed about the conversion rate and have approximately calculated the conversion of sulfur to sulfates through $\mathrm{SO}_{2}$ to be between $1-2 \%$ irrespective of sulfur level or engine design [34]. Reducing sulfur levels is not straight answer to reduce PM, since PM consists of carbonaceous soot, un-burnt or partially burnt fuel or lubricant and from fuel derived sulfates.

In one of the studies made earlier on effect of fuel properties on PM, sulfur, T90 and aromatic content seem to play a role in effecting PM [35]. They observed reduction in theses properties reduced the PM. Another study found density to have an effect on PM which increased with increase in density [36]. 
Figure 5-15 displays the effect of sulfur on emission resulted from a DDC S60 engine. The engine showed negligible emissions changes with respect to $\mathrm{NO}_{\mathrm{x}}$ or PM. The only noticeable effect was that $\mathrm{HC}$ reduced with increase in sulfur content. However, this may be attributed to other fuel properties.

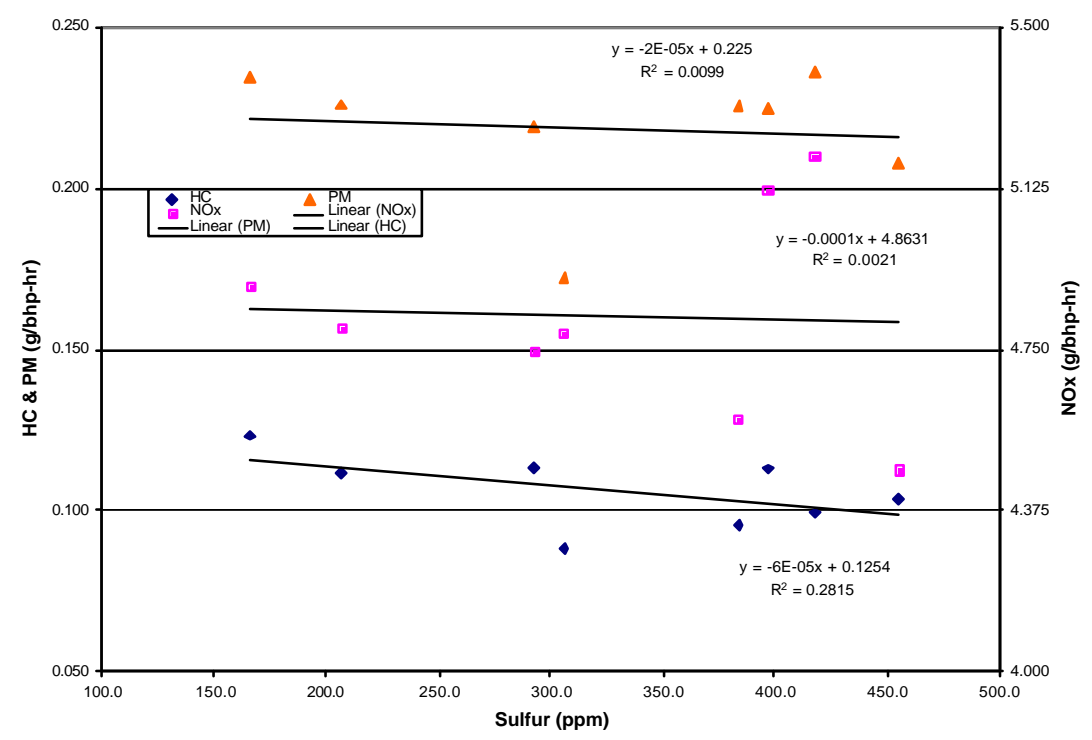

Figure 5-15 Effect of Sulfur on DDC over FTP

The modern engines response to the changes in sulfur level of the fuel is presented in Figure 5-16. When compared to the older engine, the effects were lower than the older engine. Due to lower levels of sulfur content in fuels their effect on PM is negligible as seen from the plots.

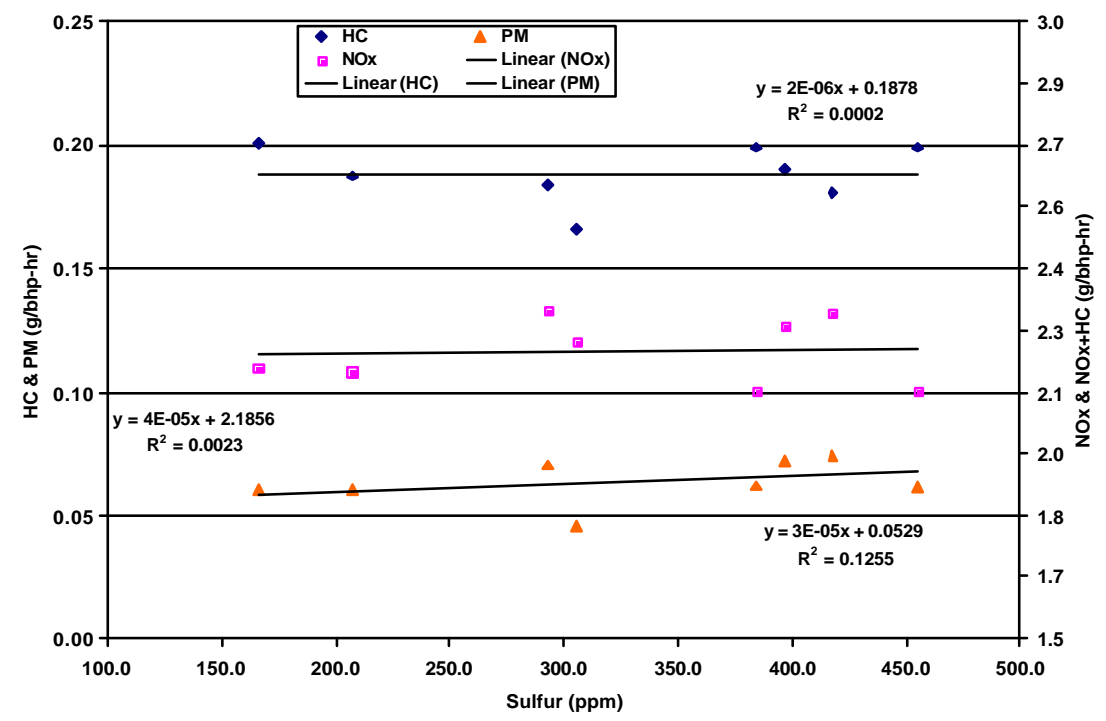

Figure 5-16 Effect of Sulfur on Cummins ISMover FTP 


\subsubsection{Effect of Total Aromatics on Emissions}

One of the concerns linked with finding the effects of total aromatics on emissions faced by prior studies was trying to decouple the intercorrelation that existed with other properties like density, cetane number and T90 [37]. However recent studies have focused on that aspect and have made efforts to decouple the correlation with other properties [38]. The influence of total aromatics has not shown any significant effect on PM, HC or CO emissions. Figure 5-17 displays the effect of total aromatics on emissions out of the DDC S60 engine. NOx emissions were affected by the changes in total aromatic content which had a $\mathrm{R}^{2}$ value of 0.2829 which indicates the increase in NOx emissions with increase in total aromatic content. HC emissions were not affected by the changes to aromatic content but PM showed a lower effect having an $\mathrm{R}^{2}$ value of 0.1131 , when compared to the NOx emissions.

Figure 5-18 displays the effect of total aromatic content for fuels tested on Cummins ISM 370. This engine showed a better response towards NOx emissions which increased with increased in aromatic content having a $\mathrm{R}^{2}$ value of 0.5168 . The $\mathrm{HC}$ emissions also responded to the changes in aromatic content of fuels having an $\mathrm{R}^{2}$ value of 0.4507 . The PM was also influenced by aromatic content but was not of much significance. Overall, the sensitivity of modern emissions towards changes in aromatic content was larger when compared to the older engine.

Polyaromatics have been a focus of recent studies, which is similar to total aromatics but have higher flame temperatures and $\mathrm{C} / \mathrm{H}$ ratios. Thus, reducing polyaromatics has had a beneficial effect on NOx emissions along with HC and PM 28]. Figure 5-19 display the effect of polyaromatics on emissions for the DDC S60 engine. The only observable effect of emissions was seen in NOx which increased with increase in polyaromatics, which has an $\mathrm{R}^{2}$ value of 0.561. PM emissions showed little response and $\mathrm{HC}$ seem to be not affected. Figure 5-20 shows the effects of polyaromatics on emissions for the Cummins ISM 370 engine. The modern engine showed better response to changes in polyaromatic content of the fuels, of which the NOx was the most significant one with $R^{2}$ value of 0.7261 and PM having a slightly lower $\mathrm{R}^{2}$ value of 0.6448 and polyaromatics had no impact on $\mathrm{HC}$ emissions. 


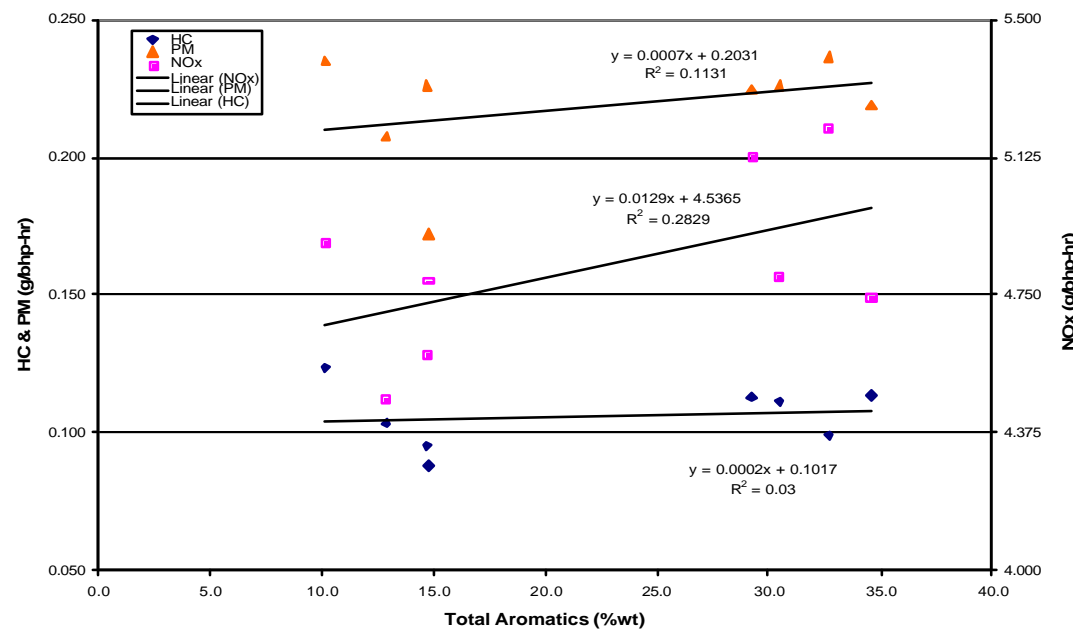

Figure 5-17 Effects of Total Aromatics on DDC S60 over FTP

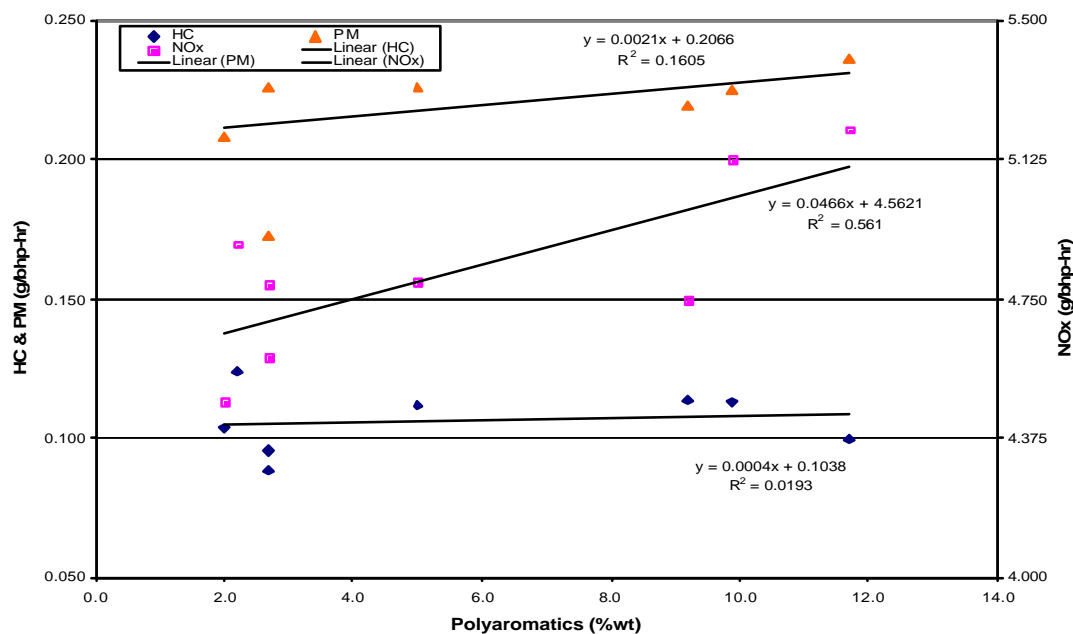

Figure 5-19 Effect of Polyaromatics on DDC S60 over FTP

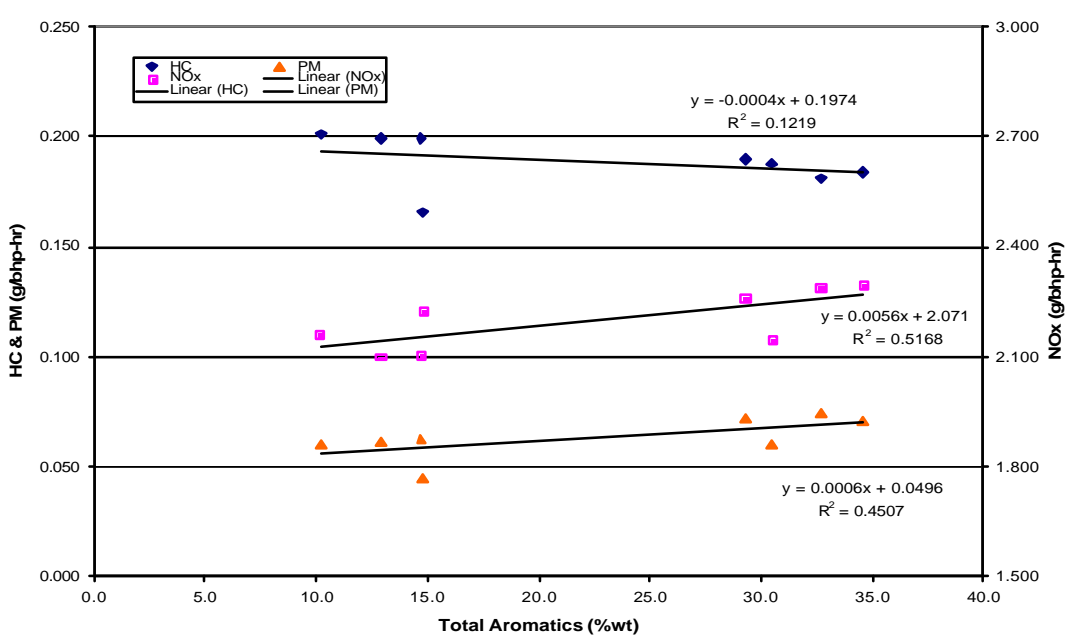

Figure 5-18 Effect of Total Aromatics on Cummins ISMover FTP

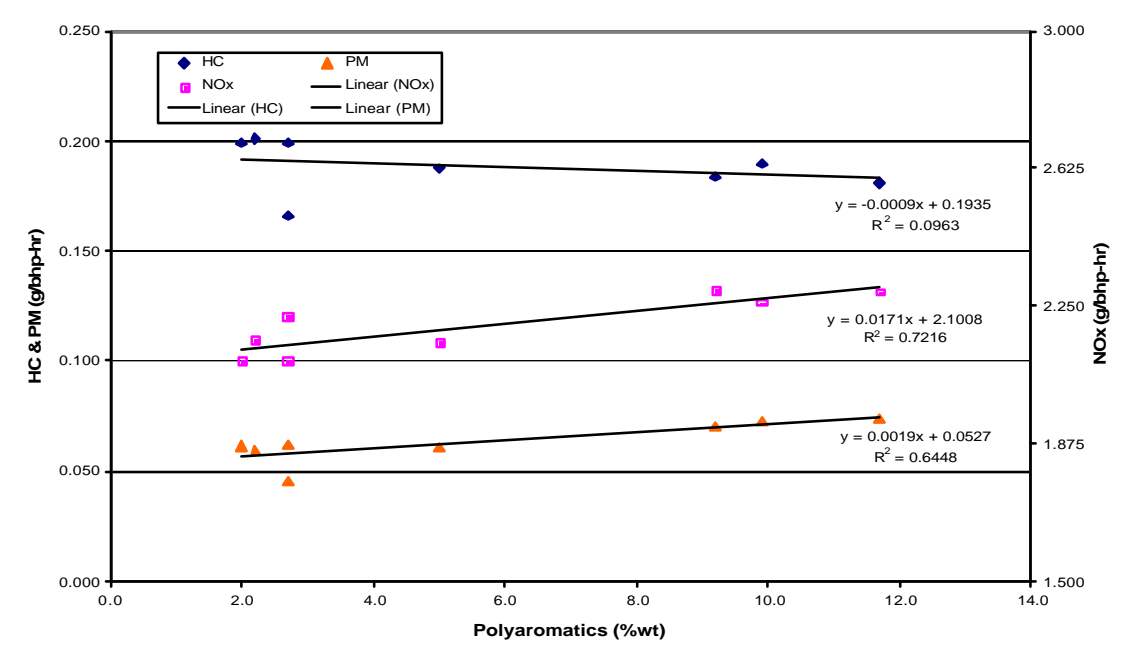

Figure 5-20 Effect of Polyaromatics on Cummins ISMover FTP 


\subsubsection{Effect of Specific Gravity on Energy Content}

Energy content is calculated by multiplying density by per mass of heating value (defined as the energy released when a unit quantity of fuel is burned), thus reflecting the influence of density on energy content. The general trend is energy content increases with increase in density which is also seen in this study in Figure 5-21.

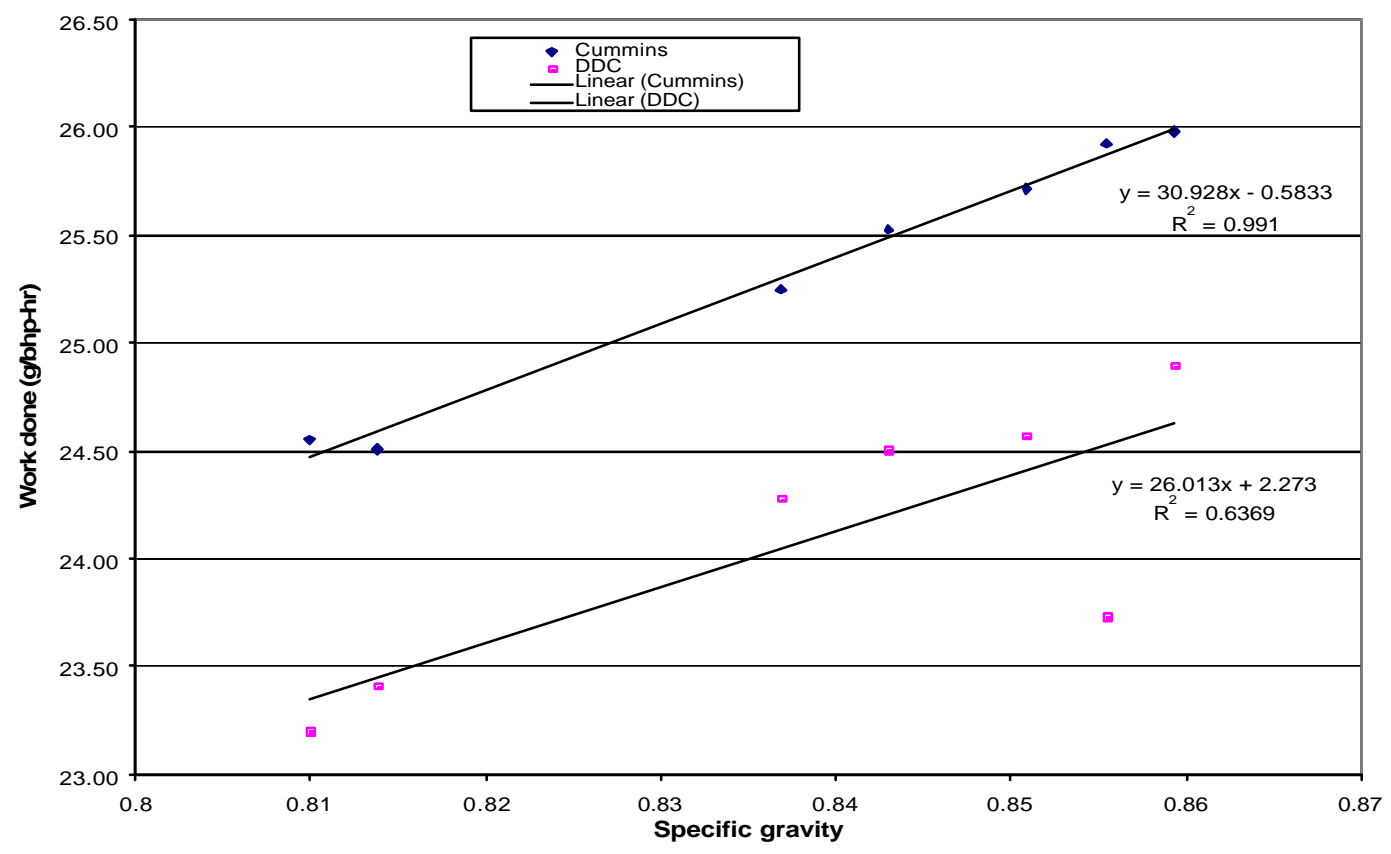

Figure 5-21 Effect of S pecific Gravity on Energy Content

The energy contents of No.1 diesel and bio-diesel blends are lower when compared to No.2 diesel fuel which is evident form the work done by these fuels. For this study energy content was not analyzed. The modern engine shows a good linear relation between energy content and specific gravity which had an $\mathrm{R}^{2}$ value of 0.991 where as the older engine shower a scattered data thus not showing a good linear relation but had an $\mathrm{R}^{2}$ value of 0.6369 which indicated that the energy content was influenced by changes in specific gravity of fuel.

Figure 5-22, displays the engine map data obtained where the plot indicates the differences in energy content (heating value) of fuels. The curves in Figure 5-22 shows a low powered fuel and higher powered fuel for both engines. Sabraton Sheetz was the fuel which showed that it contained more heat energy when compared to other fuels. It is noted that energy content was not measured as part of the fuel analysis as illustrated in Table 5-1. 


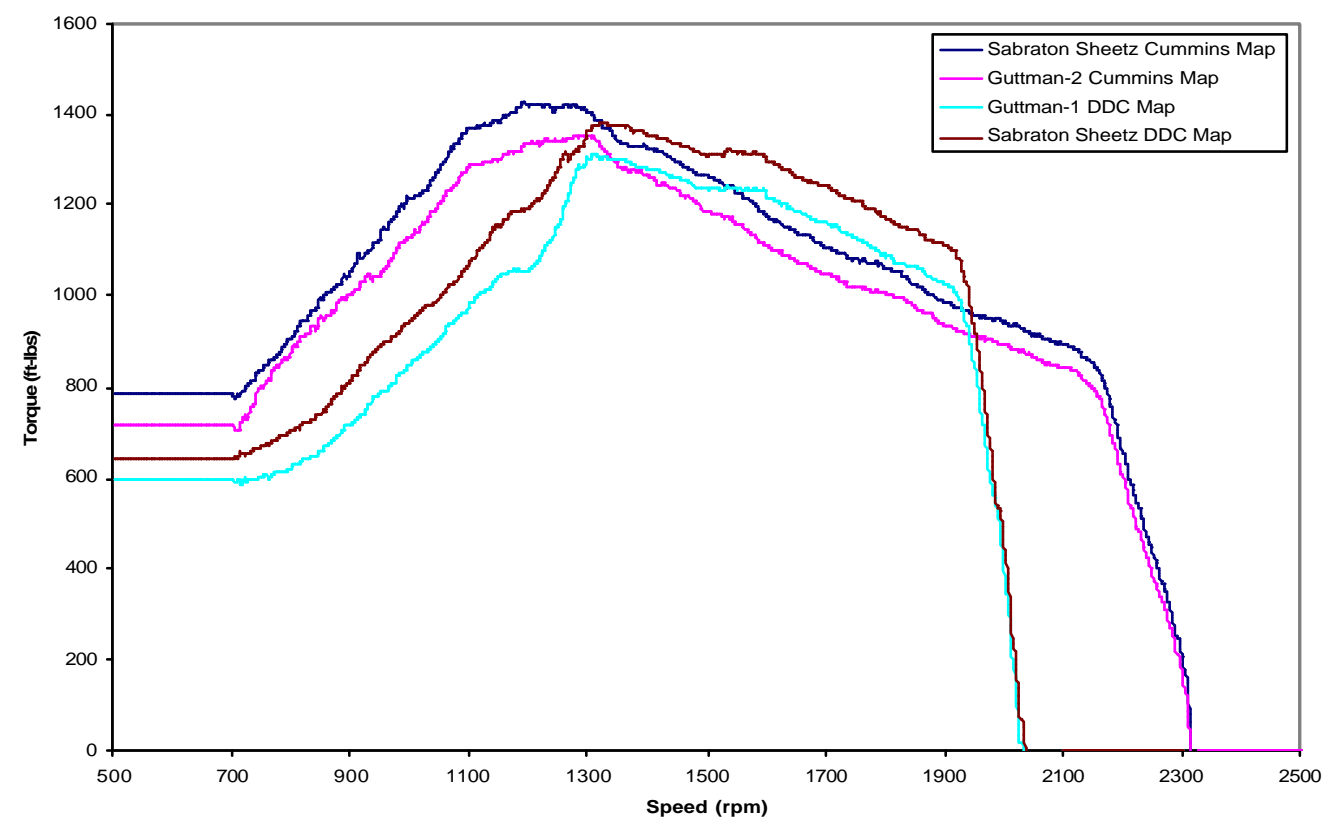

Figure 5-22 Difference in Engine Maps

\subsubsection{Effect of Volatility on Emissions}

The most important distillation points considered in diesel fuels are the back end volatility namely the T95 and T90 [29]. This study looks into the back end distillation (T90) and influence of T50 on emissions. The NOx emissions had a negative impact with increase in T50 temperatures. The PM and HC emissions showed a positive effect with increase in T50 temperatures but of little impact as seen in Figure 5-23 for the DDC S60. For the T95 temperature shown in Figure 5-24, all the emissions increased with increase in distillation temperatures with NOx being the most influenced out of the three emissions.

The Cummins ISM 370 responded with greater sensitivity to the changes in T50 temperature. The most affected emissions were the $\mathrm{HC}$ emissions and NOx as seen in Figure 5-25, where HC had a beneficial impact with increase in T50 temperatures and NOx had a negative impact with increase in T50 temperatures. The $\mathrm{R}^{2}$ value for $\mathrm{HC}$ and NOx emissions was of the order of 0.7903 and 0.7638 , respectively. In the case of T95 temperatures, the emissions were not affected which is evident from the graph presented in Figure 5-26. 


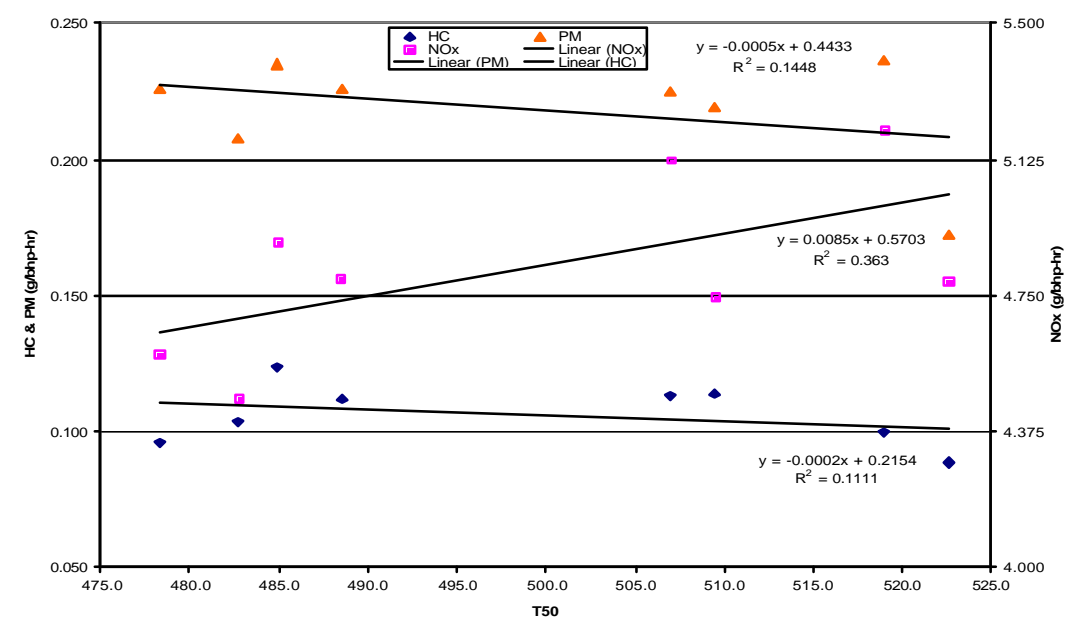

Figure 5-23 Effect of T50 on DDC S60

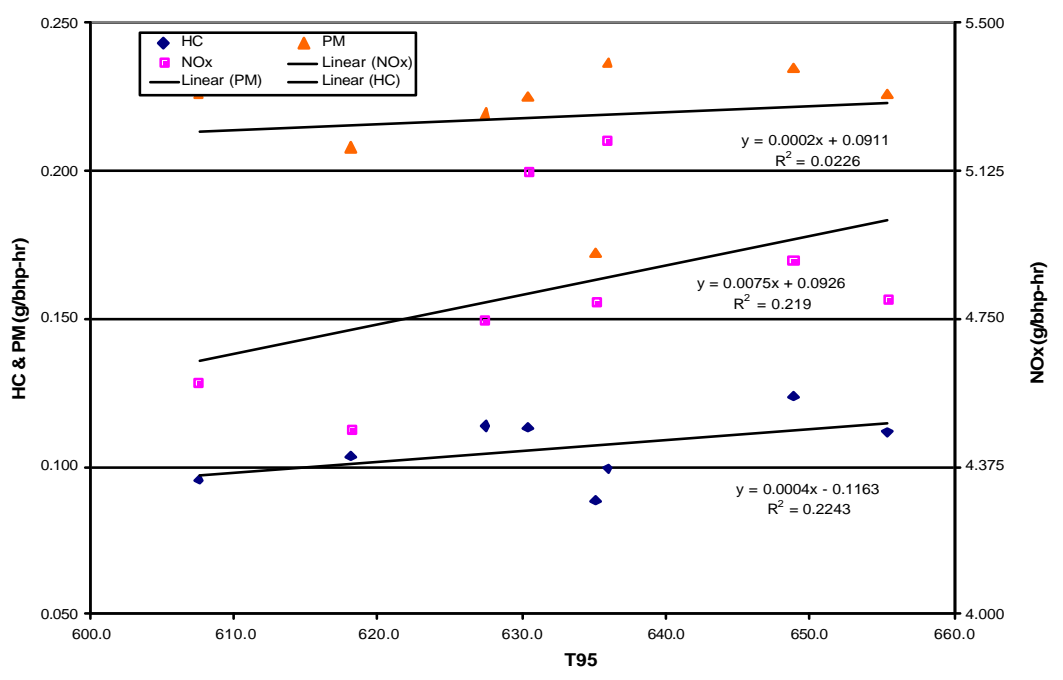

Figure 5-25 Effect of T95 on DDC S60

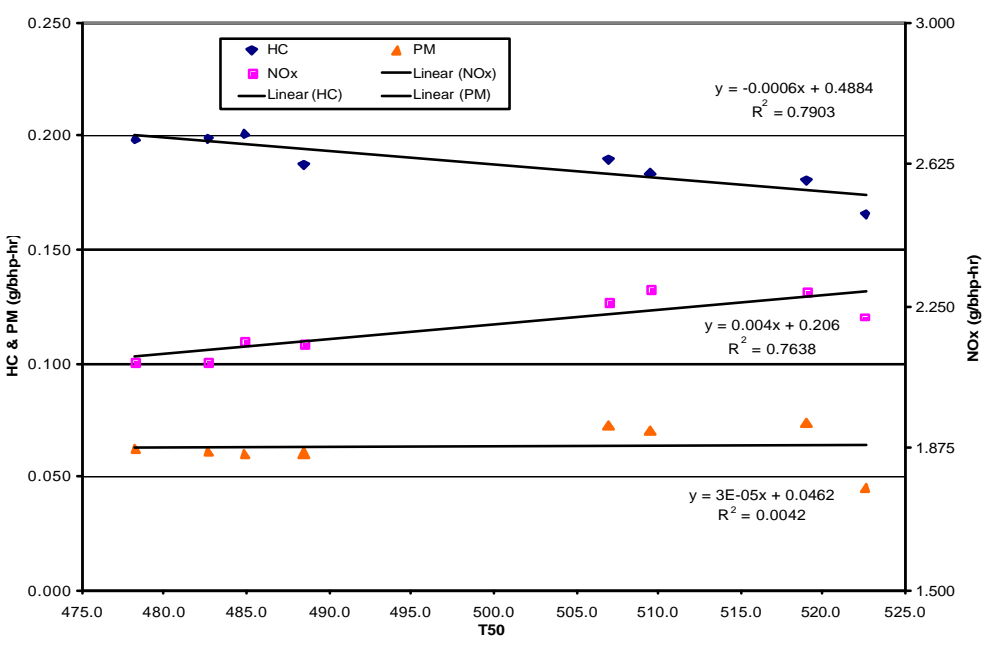

Figure 5-24 Effects of T50 on Cummins ISM370

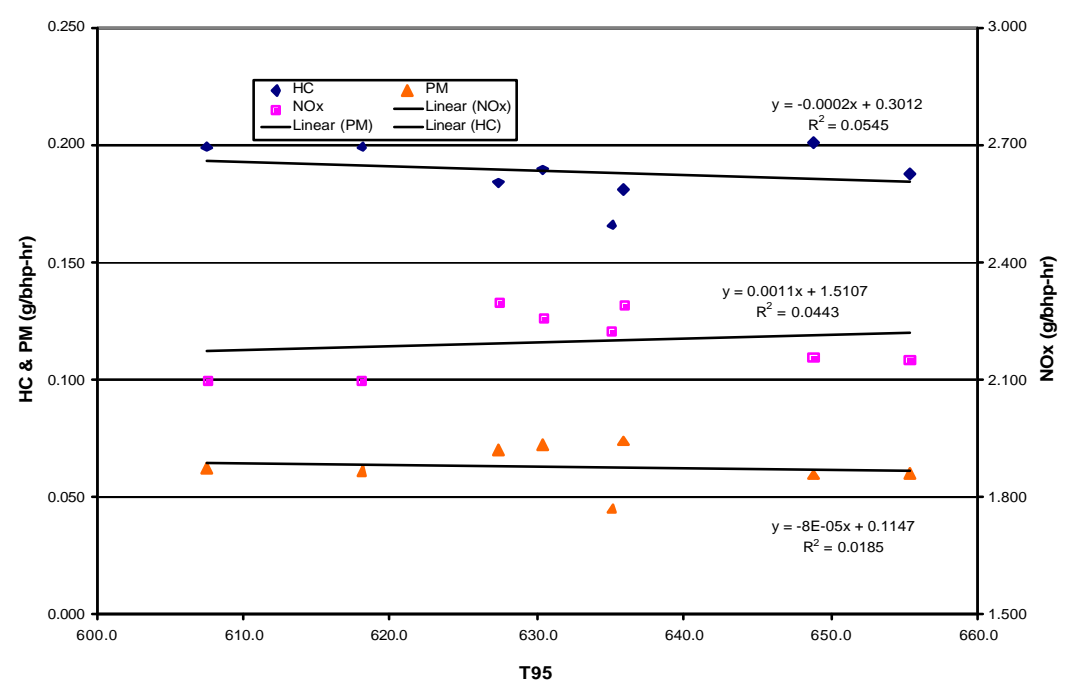

Figure 5-26 Effect of T95 on Cummins ISM 375 


\subsection{Decoupling Fuel Properties}

Finding the correlation between fuel properties was an important aspect so as to determine individual fuel properties that influenced the emissions. This was one of the problems faced by prior researchers who were not able to do decouple the correlation between fuel properties and were ambiguous about the results obtained. So, correlations were used to determine fuel properties that were correlated to one another. This was achieved by recent studies using statistical analysis methods for correlation and were successful in identify fuel variables.

To determine the correlation between fuel properties, the common and efficient method used was the Pearson Correlation Coefficients method which is also being used in this study to correlate the results made by other studies. The coefficients obtained are shown in Table 5-10, which was calculated using built-in program called Correlation under data analysis tool in Microsoft Excel. A strong correlation existed between fuel properties if the Pearson correlation coefficient was equal to 1 . The correlation coefficients greater than 0.9 were considered good to show that the two properties correlated well. The converse holds good for the values which were close to 0 indicating that there was no correlation existing between them. The coefficients with a positive sign signified that the two properties were positively correlated and the negative sign signified the inverse correlation.

The properties that showed correlations were identified as those having correlation coefficient greater than 0.90 for this study. Among the fuels tested and examining the results obtained as shown in Table 5-10, specific gravity showed correlation with viscosity and cetane number and hydrogen content. Specific gravity and viscosity had a positive relationship where as hydrogen and cetane had an inverse relationship.

Additionally, correlations between fuel properties and $\mathrm{HC}, \mathrm{NOx}, \mathrm{PM}$ and $\mathrm{CO}$ emissions were also made so as to see which fuel property correlated with emissions. 
Table 5-10 Pearson Correlation Coefficient

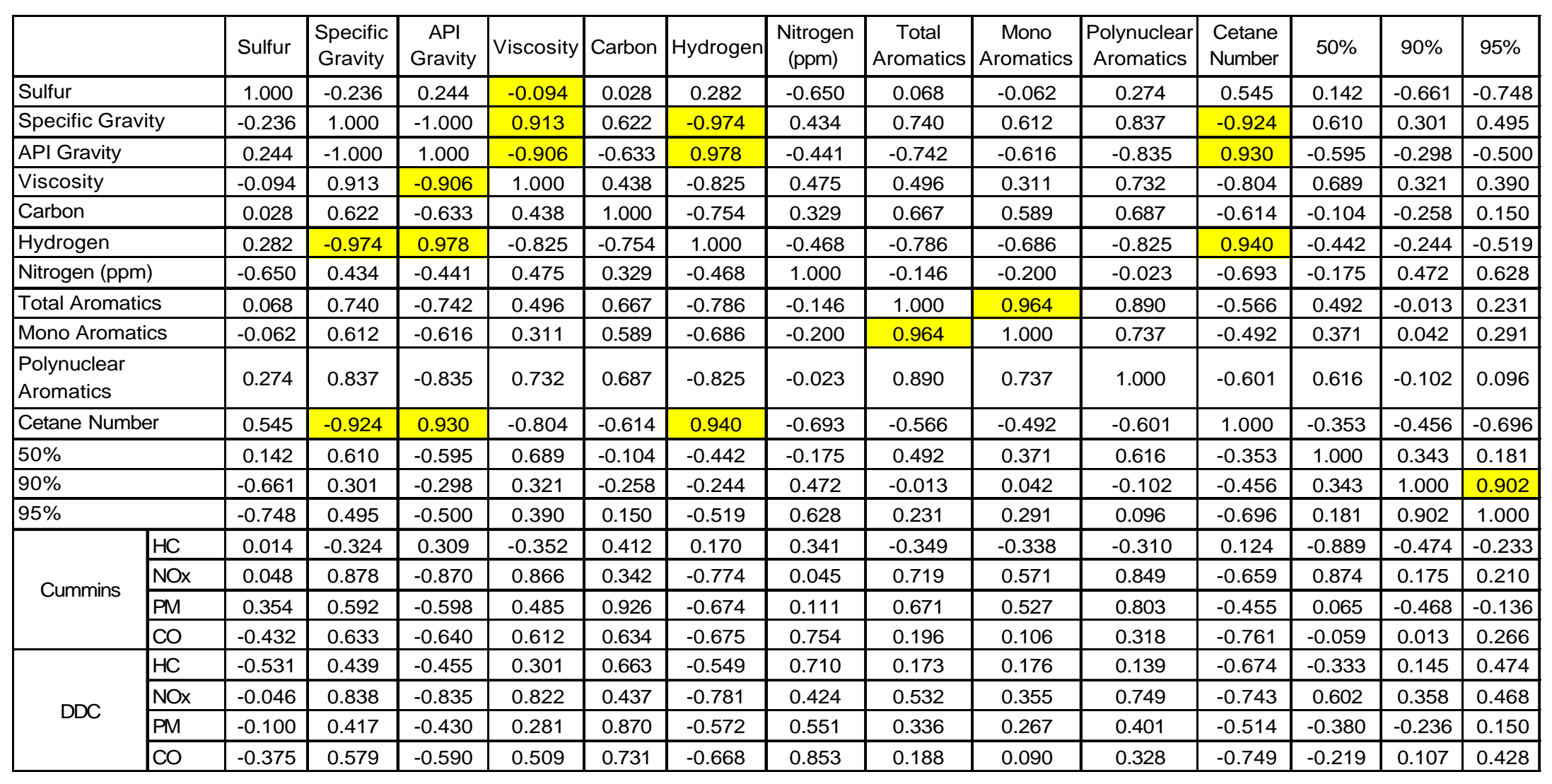




\subsection{Prediction of Emissions from Mathematical Models}

A mathematical model was created to predict the transient FTP emissions using statistical analysis software (SAS). Fuel properties were selected which did not have any correlation with other fuel properties. The selected fuel properties included sulfur, specific gravity, cetane number, viscosity, hydrogen, carbon content, total aromatics and T95 distillation temperatures. The best model was selected based on the best correlation from the selected fuel properties. Few properties were selected as primary variables (total aromatic content, sulfur and carbon content) which were used in all equations to predict emissions. The secondary variables were those which differed for different emissions. Before using the variables to create models, the variable were divided into different groups which are shown in Table 5-11 and Table 5-12 and shows the designation used for fuel variables.

Table 5-11Combination of Fuel Properties

\begin{tabular}{|l|c|c|c|c|c|}
\hline \multicolumn{7}{|c|}{ Combinations } \\
\hline Group-1 & $\mathrm{X} 1$ & $\mathrm{X} 2$ & $\mathrm{X} 5$ & $\mathrm{X} 8$ & $\mathrm{X} 14$ \\
\hline Group-2 & $\mathrm{X} 1$ & $\mathrm{X} 4$ & $\mathrm{X} 5$ & $\mathrm{X} 8$ & $\mathrm{X} 14$ \\
\hline Group-3 & $\mathrm{X} 1$ & $\mathrm{X} 6$ & $\mathrm{X} 5$ & $\mathrm{X} 8$ & $\mathrm{X} 14$ \\
\hline Group-4 & $\mathrm{X} 1$ & $\mathrm{X} 11$ & $\mathrm{X} 5$ & $\mathrm{X} 8$ & $\mathrm{X} 14$ \\
\hline
\end{tabular}

Table 5-12 Fuel Variables

\begin{tabular}{|c|c|c|c|c|c|c|c|}
\hline $\mathrm{X} 1$ & $\mathrm{X} 2$ & $\mathrm{X} 4$ & $\mathrm{X} 5$ & $\mathrm{X} 6$ & $\mathrm{X} 8$ & $\mathrm{X} 11$ & $\mathrm{X} 14$ \\
\hline Sulfur & $\begin{array}{c}\text { Specific } \\
\text { gravity }\end{array}$ & Viscosity & Carbon & Hydrogen & $\begin{array}{c}\text { Total } \\
\text { Aromatics }\end{array}$ & $\begin{array}{c}\text { Cetane } \\
\text { Number }\end{array}$ & $\mathrm{T} 50$ \\
\hline
\end{tabular}

Shown below are the best mathematical modeled equations obtained from the SAS program.

For Cummins ISM 370,

$H C(p)=-0.884-7.98 E-7 *(X 1)-0.020 *(X 4)+0.014 *(X 5)-1.09 * E-3 *(X 8)-6 \cdot 90 E-6 *(X 14)$
$N O x(p)=2.03+1.25 E-4 *(X 1)+5.12(X 2)-4.03 E-2 *(X 5)+1.70 E-6 *(X 8)-1.16 E-4 *(X 14)$
$P M(p)=-0.615+1.23 E-4 *(X 1)+0.150 *(X 6)-7.18 E-4 *(X 5)+7.10 E-6 *(X 8)-1.12 E-4 *(X 14)$

For DDC S60,

$$
\begin{aligned}
& H C(p)=-0.843-5.31 E-6 *(X 1)-3.71 E-2 *(X 11)+1.07 E-2 *(X 5)-5.79 E-4 *(X 8)-3.90 E-6 *(X 14) \\
& N O(p)=-10.5+1.44 E-4 *(X 1)+13.7 *(X 6)-0.017 *(X 5)-8.30 E-4 *(X 8)-8.01 E-4 *(X 14) \\
& P M(p)=-1.72-2.10 E-5(X 1)-0.051 *(X 4)+0.023 *(X 5)-8.52 E-5(X 8)+5.32-6 *(X 14)
\end{aligned}
$$

Where (p) is the predicted value. 
The equation shown above predicts the emissions in $\mathrm{g} / \mathrm{bhp}-\mathrm{hr}$, where the predicted emission equation is calculated using the intercept indicated by the first number in the equation along with the coefficients of the fuel properties. The positive sign against the coefficients signifies that emissions have a linear relation with the fuel property and negative signs signifies an inverse relation between emissions and fuel properties. The $\mathrm{R}^{2}$ values obtained from each group for HC, NOx and PM are shown in Table 5-13. The best related model was used for predicting emissions as shown above. The comparison between predicted values and measured emissions for both engines are shown in Table 5-14 and Table 5-15. The SAS results obtained are attached in Appendix E.

Table 5-13 $\mathbf{R}^{2}$ Values for All Models

\begin{tabular}{|l|l|c|c|c|c|c|c|c|c|}
\hline \multicolumn{5}{|c|}{ Cummmins FTP } & \multicolumn{5}{c|}{ DDC FTP } \\
\hline \multicolumn{2}{|c|}{ Variables } & $\mathrm{HC}$ & $\mathrm{NOx}$ & $\mathrm{PM}$ & \multicolumn{2}{|c|}{ Variables } & $\mathrm{HC}$ & $\mathrm{NOx}$ & $\mathrm{PM}$ \\
\hline Group-1 & $\mathrm{R}^{2}$ Value & 0.9919 & 0.9846 & 0.9968 & Group-1 & $\mathrm{R}^{2}$ Value & 0.854 & 0.8487 & 0.8767 \\
\hline Group-2 & $\mathrm{R}^{2}$ Value & 0.9992 & 0.979 & 0.9943 & Group-2 & $\mathrm{R}^{2}$ Value & 0.8532 & 0.7681 & 0.8774 \\
\hline Group-3 & $\mathrm{R}^{2}$ Value & 0.992 & 0.9638 & 0.9984 & Group-3 & $\mathrm{R}^{2}$ Value & 0.853 & 0.8747 & 0.8763 \\
\hline Group-4 & $\mathrm{R}^{2}$ Value & 0.9881 & 0.9806 & 0.9969 & Group-4 & $\mathrm{R}^{2}$ Value & 0.8547 & 0.8656 & 0.8768 \\
\hline
\end{tabular}

Table 5-14 Comparison between Measured and Predicted Emissions for Cummins

\begin{tabular}{|c|c|c|c|c|c|c|}
\hline \multicolumn{7}{|c|}{ Cummins ISM 370} \\
\hline \multirow[b]{2}{*}{ Fuel } & \multicolumn{3}{|c|}{ Measured Emissions } & \multicolumn{3}{|c|}{ Predicted Emissions } \\
\hline & $\begin{array}{c}\mathrm{HC} \\
(\mathrm{g} / \mathrm{bhp}-\mathrm{hr})\end{array}$ & $\begin{array}{c}\text { NOx } \\
\text { (a/bhp-hr) }\end{array}$ & $\begin{array}{c}\mathrm{PM} \\
\text { (a/bhp-hr) }\end{array}$ & $\begin{array}{c}\mathrm{HC}(\mathrm{p}) \\
(\mathrm{g} / \mathrm{bhp}-\mathrm{hr})\end{array}$ & $\begin{array}{c}\mathrm{NOx}(\mathrm{p}) \\
\text { (q/bhp-hr) }\end{array}$ & $\begin{array}{c}\text { PM (p) } \\
\text { (a/bhp-hr) }\end{array}$ \\
\hline Sabraton Kroger & 0.184 & 2.296 & 0.070 & 0.185 & 2.225 & 0.071 \\
\hline \multicolumn{4}{|c|}{ \% Difference } & -0.3 & 3.0 & -0.8 \\
\hline Guttman-1 & 0.199 & 2.101 & 0.061 & 0.2 & 2.066 & 0.062 \\
\hline \multicolumn{4}{|c|}{ \% Difference } & -0.4 & 1.6 & -1.0 \\
\hline Shell Bakersfield & 0.201 & 2.161 & 0.060 & 0.201 & 2.145 & 0.06 \\
\hline \multicolumn{4}{|c|}{ \% Difference } & -0.1 & 1.0 & 0.0 \\
\hline CECD1 & 0.188 & 2.149 & 0.060 & 0.188 & 2.103 & 0.06 \\
\hline \multicolumn{4}{|c|}{ \% Difference } & -0.3 & 2.1 & 0.3 \\
\hline Sabraton Sheetz & 0.181 & 2.290 & 0.074 & 0.182 & 2.249 & 0.0773 \\
\hline \multicolumn{4}{|c|}{ \% Difference } & -0.6 & 1.8 & 0.7 \\
\hline Mileground BP & 0.190 & 2.259 & 0.072 & 0.188 & 2.212 & 0.072 \\
\hline \multicolumn{4}{|c|}{$\%$ Difference } & -0.1 & 2.1 & 0 \\
\hline Guttman-2 & 0.199 & 2.102 & 0.062 & 0.199 & 2.092 & 0.061 \\
\hline \multicolumn{4}{|c|}{$\%$ Difference } & -0.4 & 0.5 & $\overline{1.4}$ \\
\hline Biodiesel & 0.166 & 2.223 & 0.045 & 0.165 & 2.201 & 0.045 \\
\hline \multicolumn{4}{|c|}{$\%$ Difference } & -0.1 & 1.0 & 0.2 \\
\hline
\end{tabular}


Table 5-15 Comparison between Measured and Predicted Emissions for DDC

\begin{tabular}{|c|c|c|c|c|c|c|}
\hline \multicolumn{7}{|c|}{ DDC S60 } \\
\hline \multirow[b]{2}{*}{ Fuel } & \multicolumn{3}{|c|}{ Measured Emissions } & \multicolumn{3}{|c|}{ Predicted Emissions } \\
\hline & $\begin{array}{c}\mathrm{HC} \\
\text { (g/bhp-hr) }\end{array}$ & $\begin{array}{c}\text { NOx } \\
\text { (g/bhp-hr) }\end{array}$ & $\begin{array}{c}\text { PM } \\
\text { (g/bhp-hr) }\end{array}$ & $\begin{array}{c}\mathrm{HC}(\mathrm{p}) \\
\text { (g/bhp-hr) }\end{array}$ & 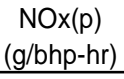 & $\begin{array}{c}\text { PM (p) } \\
\text { (g/bhp-hr) }\end{array}$ \\
\hline Sabraton Kroger & 0.114 & 4.745 & 0.219 & 0.111 & 4.872 & 0.227 \\
\hline \multicolumn{4}{|c|}{$\%$ Difference } & 3.2 & -2.7 & -3.8 \\
\hline Guttman-1 & 0.104 & 4.469 & 0.208 & 0.1 & 4.607 & 0.217 \\
\hline \multicolumn{4}{|c|}{ \% Difference } & 4.0 & -3.0 & -4.5 \\
\hline \multirow[t]{2}{*}{ Shell Bakersfield } & 0.124 & 4.896 & 0.235 & 0.124 & 4.896 & 0.235 \\
\hline & \multicolumn{3}{|c|}{ \% Difference } & -0.1 & -0.1 & 0 \\
\hline CECD1 & 0.112 & 4.798 & 0.226 & 0.113 & 4.76 & 0.223 \\
\hline \multicolumn{4}{|c|}{$\%$ Difference } & -1.0 & 1.0 & 1.0 \\
\hline Sabraton Sheetz & 0.099 & 5.203 & 0.236 & 0.106 & 5.188 & 0.227 \\
\hline \multicolumn{4}{|c|}{$\%$ Difference } & -6.9 & 0.3 & 3.8 \\
\hline Mileground BP & 0.113 & 5.125 & 0.225 & 0.108 & 5.027 & 0.229 \\
\hline \multicolumn{4}{|c|}{$\%$ Difference } & 4.8 & 1.9 & 1.7 \\
\hline Guttman-2 & 0.096 & 4.590 & 0.226 & 0.102 & 4.458 & 0.215 \\
\hline \multicolumn{4}{|c|}{$\%$ Difference } & -5.8 & 2.9 & 4.7 \\
\hline Biodiesel & 0.088 & 4.789 & 0.172 & 0.087 & 4.798 & 0.173 \\
\hline \multicolumn{4}{|c|}{$\%$ Difference } & 1.0 & -0.2 & -0.3 \\
\hline
\end{tabular}

\subsection{Influence of $\mathbf{F}$ uel Properties on Steady State Modes in ESC}

To study the effect of fuel properties changes in steady state cycle, two modes from the 13 mode ESC were examined. The NOx emissions from all the 13 modes were plotted for both engines tested on Sabraton Kroger fuel and are displayed in Figure 5-28.

An interesting observation was made, where the peaks for NOx formation were in different modes for both the engines. For the Cummins ISM maximum NOx formation was in mode 8 where as for DDC in mode 10 evident from Figure 5-28

High NOx formation is normally associated at higher loads because of an increase in boost pressure and subsequent peak cylinder pressure. This is evident from mode 10 which was at $100 \%$ load and higher speed when compared to mode 8 which was at $100 \%$ load but at lower speed in the DDC S60 engine. The Cummins ISM doesn't show the same trend as seen in DDC S60 which can be seen in Figure 5-28. 


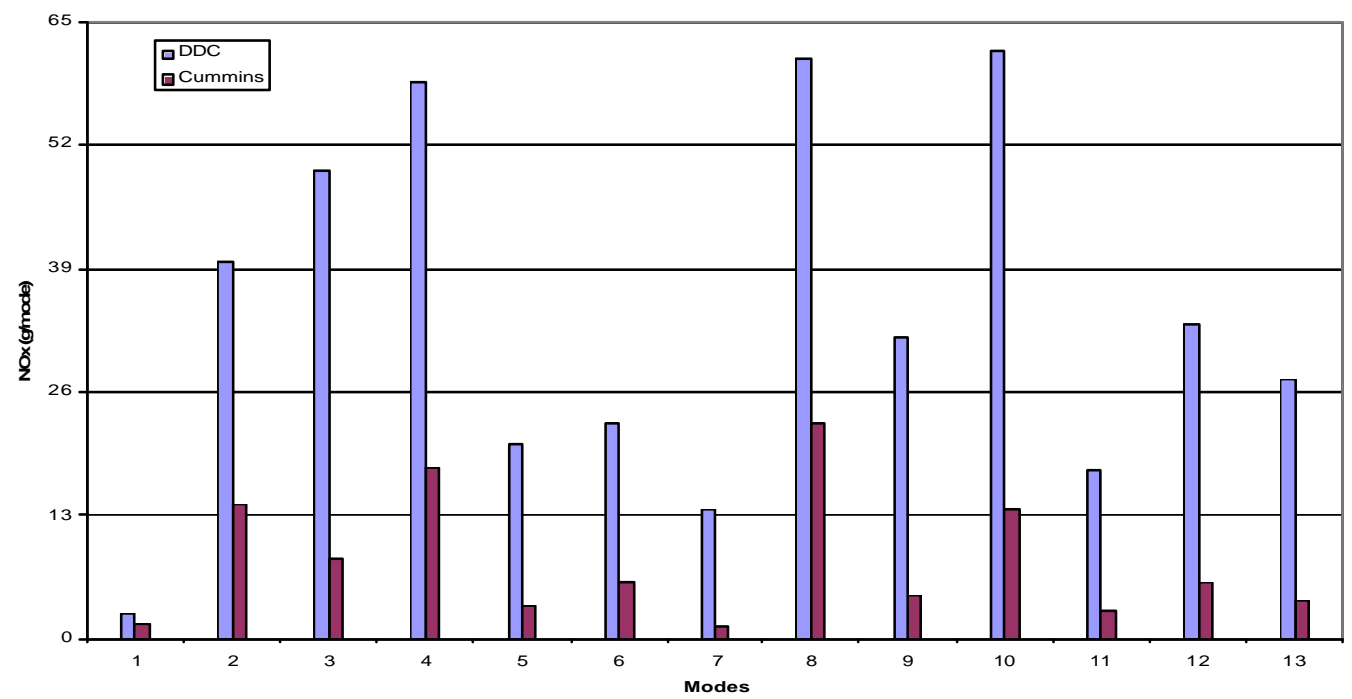

Figure 5-27 Comparison of $\mathrm{NO}_{\mathbf{x}}$ Emissions Over the 13 Mode ESC for the Two Engines

Figure 5-28 shows peak NOx emissions at mode 8 for the modern engine in comparison with the older engine. This is due to the effect of EGR which is sensitive to the A/F ratio conditions. This observation was made by a study on effect of EGR on emission which confirms that deterioration in combustion is predominant at higher load and low speed and low boost pressure due to decrease in A/F ratio [39]. Figure 5-29 displays the $\mathrm{NO}_{\mathrm{x}}$ emissions for modes 8 and 10 for all fuels.

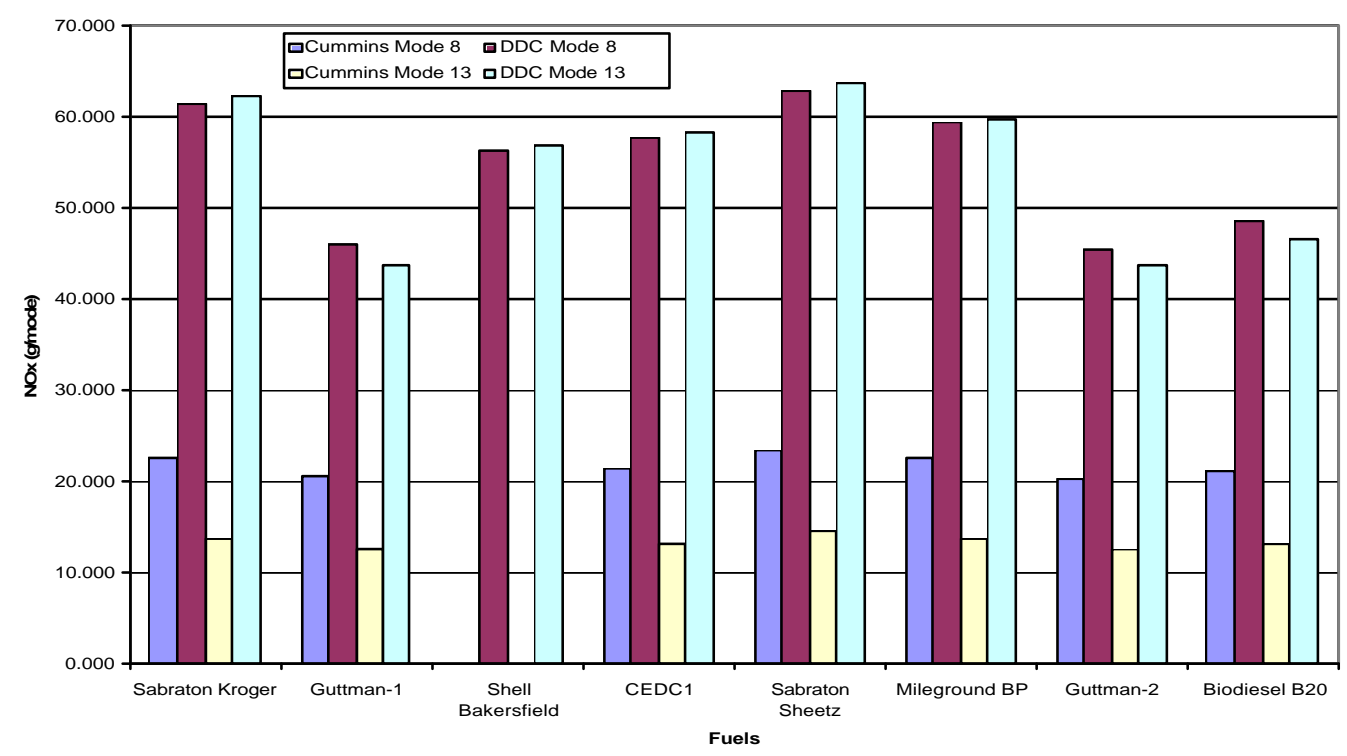

Figure 5-28 NOx emissions of 8 mode and 13 mode of ESC 


\subsection{Effect of Cetane on NOx Emissions in ESC}

Figure 5-29 represents NOx emissions from three modes of the ESC for both the engines to compare the effects of cetane number on NOx emissions. Guttman-1 and Sabraton fuel was used which represented a clean and dirty fuel (based on NOx emissions). The older engine showed larger reductions in NOx emissions between $30 \%$ to $40 \%$ when compared to modern engine which showed less than 10\% reduction as seen in Figure 5-29. However the observation made may not be general since ESC data collected was for one test on each fuel in this study.

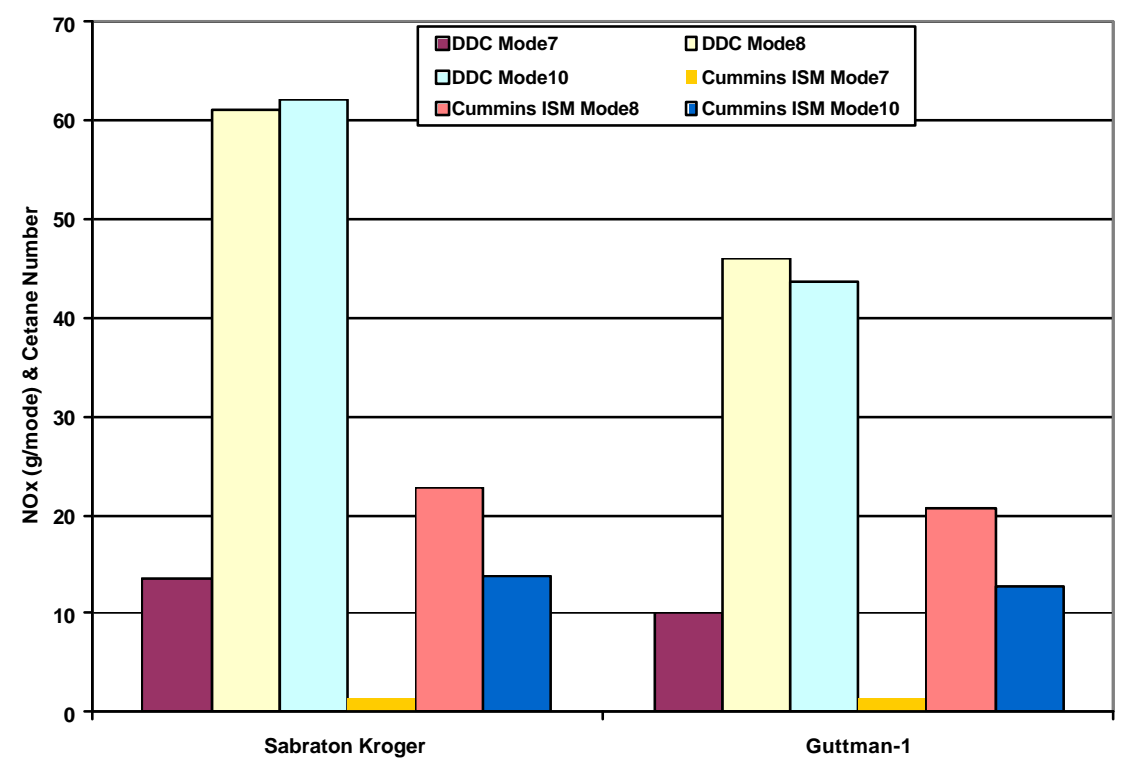

Figure 5-29 Cetane Effects on NOx in Some ESC Modes

\subsection{Comparison between Conventional and Biodiesel blend}

Biodiesel is one of the alternative fuels being used which is become an important substitute to conventional diesels which are either plant or animal extract. The added advantage of using biodiesels include it is produced from renewable resources, is biodegradable and most important of all is its potential to reduce emissions.

A B20 blend was used for this study, as the name suggests it composed of $20 \%$ of Biodiesel and $80 \%$ conventional diesel. The biodiesel used for mixing was from a local supplier, which was a soybean extract. B20 has an edge over other alternative fuels due to its 
compatibility with the diesel engines which doesn't need any modification for using it. This fuel was tested over the FTP and ESC to see the effect of B20. The average data obtained from three hot starts over the FTP cycle is displayed in Table 5-15 for the Cummins ISM and DDC S60. Reductions in emissions were observed where the percentage difference with a positive sign shows a reduction from conventional diesel fuel and negative sign signifies an increase. The most significant reduction was seen in PM which reduced by $27 \%$ for modern engine and $24 \%$ on the older engine, $\mathrm{HC}$ emissions reduced by $17 \%$ for the modern engine and $8 \%$ on older engine. However the NOx went up by $5 \%$ or $6 \%$ which was one of the negative attributes of using $\mathrm{B} 20 . \mathrm{CO}$ reduction was of $5 \%$ on the modern and $12 \%$ on the older and negligible difference was seen in $\mathrm{CO}_{2}$.

Table 5-16 Comparison between conventional and Biodiesel over FTP

\begin{tabular}{|l|c|c|c|c|c|c|}
\hline & \multicolumn{3}{|c|}{ Cummins FTP } & \multicolumn{3}{c|}{ DDC FTP } \\
\cline { 2 - 7 } & Guttman-2 & $\begin{array}{c}\text { Biodiesel } \\
\text { B20 }\end{array}$ & \% Difference & Guttman-2 & Biodiesel B20 & \% Difference \\
\hline $\mathrm{HC}$ (g/bhp-hr) & 0.199 & 0.166 & -16.7 & 0.096 & 0.088 & -7.7 \\
\hline $\mathrm{CO}$ (g/bhp-hr) & 0.551 & 0.524 & -4.8 & 2.612 & 2.300 & -12.0 \\
\hline $\mathrm{CO} 2$ (g/bhp-hr) & 577.8 & 575.0 & -0.5 & 531.3 & 530.6 & -0.1 \\
\hline $\mathrm{NOx}$ (g/bhp-hr) & 2.102 & 2.223 & 5.7 & 4.590 & 4.789 & 4.3 \\
\hline PM (g/bhp-hr) & 0.062 & 0.045 & -27.1 & 0.226 & 0.172 & -23.7 \\
\hline Actual work (bhp-hr) & 24.507 & 24.377 & -0.5 & 23.407 & 23.593 & 0.8 \\
\hline BSFC (lb/bhp-hr) & 0.413 & 0.426 & 3.2 & 0.380 & 0.390 & 2.5 \\
\hline Fuel consumption (lb) & 10.118 & 10.388 & 2.7 & 8.895 & 9.191 & 3.3 \\
\hline
\end{tabular}

A study was made by Colorado Institute for fuels and High-Altitude Engine Research, in 1996 which studied the effect of neat biodiesel (100\%) and biodiesel blended with conventional diesel (B20, B35, B65). The observation made in this study was that $\mathrm{NO}_{\mathrm{x}}$ increased with increased in the percentage of biodiesel in the fuel. HC, CO and PM decreased with increase in percentage of biodiesel [40].

The data obtained from ESC is displayed in Table 5-17, shows a significant reduction in $\mathrm{HC}, \mathrm{PM}$ and $\mathrm{CO}$. The $\mathrm{NO}_{\mathrm{x}}$ increase was similar to that seen in FTP. 
Table 5-17 Comparison between Conventional and Biodiesel over ESC

\begin{tabular}{|l|c|c|c|c|c|c|}
\hline & \multicolumn{3}{|c|}{ Cummins ESC } & \multicolumn{3}{c|}{ DDC ESC } \\
\cline { 2 - 7 } & Guttman-2 & $\begin{array}{c}\text { Biodiesel } \\
\text { B20 }\end{array}$ & $\%$ Difference & Guttman-2 & $\begin{array}{c}\text { Biodiesel } \\
\text { B20 }\end{array}$ & $\%$ Difference \\
\hline HC (g/bhp-hr) & 0.109 & 0.090 & -17.1 & 0.050 & 0.048 & -5.0 \\
\hline CO (g/bhp-hr) & 0.308 & 0.286 & -7.2 & 3.008 & 2.742 & -8.8 \\
\hline CO2 (g/bhp-hr) & 510.7 & 512.1 & 0.3 & 469.3 & 471.8 & 0.6 \\
\hline NOx (g/bhp-hr) & 1.866 & 1.961 & 5.1 & 7.350 & 7.746 & 5.4 \\
\hline PM (g/bhp-hr) & 0.018 & 0.013 & -23.7 & 0.053 & 0.041 & -22.9 \\
\hline Actual work (bhp-hr) & 4.055 & 4.036 & -0.5 & 3.846 & 3.875 & 0.8 \\
\hline BSFC (lb/bhp-hr) & 168.609 & 169.571 & 0.6 & 244.300 & 243.377 & -0.4 \\
\hline
\end{tabular}




\section{CONCLUSIONS}

The changes in emissions due to fuel property differences appear to be small when compared to the emission levels achieved by changes in technologies. But the changes are significant which help in achieving the lower emissions standards being set by the regulatory boards. It was imperative to assess fuel properties that affect emissions and to observe the sensitivity of engines to fuel changes. This was achieved in this study which tested fuels that had a wide range of fuel properties on two different engines, representing early and current production engine technologies. The observations on regulatory emissions measured from different fuels exercised over engine dynamometer cycles on both engines are as follows.

Correlation of NOx emissions with fuel properties:

- NOx showed good correlations with density, viscosity, polyaromatics and T50 which had a beneficial effect on NOx emissions. From the emissions point of view a decrease in these fuel properties resulted in a decrease in NOx emissions. This was observed in both engines but the modern engine showed better correlation when compared to the older engine. One of the fuel properties which is influential on $\mathrm{NO}_{\mathrm{x}}$ and which was not studied in detail by previous sudies is viscosity. The correlation coefficient values between fuel properties and NOx emissions are shown in Table 6-1 along with the LR $\left(\mathrm{R}^{2}\right.$ value). The negative sign for Pearson Correlation Coefficient (PCC) indicate a inverse relation between fuel property and emissions.

- Cetane number, one of the influential properties on NOx emissions, did show a correlation but was not as effective when compared to the other properties. The older engine showed more sensitivity to the changes in cetane number when compared to the modern engine as seen in Table 6-1.

Table 6-1 Correlation Coefficients between Fuel Properties and NOx

\begin{tabular}{|c|c|c|c|c|c|}
\hline \multicolumn{2}{|c|}{ Cummins } & $\begin{array}{c}\text { Specific } \\
\text { Gravity }\end{array}$ & Polyaromatics & T50 & $\begin{array}{c}\text { Cetane } \\
\text { Number }\end{array}$ \\
\hline \multirow{2}{*}{ NOx } & PCC & 0.8783 & 0.8495 & 0.8740 & -0.6593 \\
\cline { 2 - 6 } & LR & 0.7713 & 0.7216 & 0.7638 & 0.4347 \\
\hline \multicolumn{2}{|c|}{ DDC } & $\begin{array}{c}\text { Specific } \\
\text { Gravity }\end{array}$ & Polyaromatics & T50 & $\begin{array}{c}\text { Cetane } \\
\text { Number }\end{array}$ \\
\hline \multirow{2}{*}{ NOx } & PCC & 0.8379 & 0.7490 & 0.6025 & -0.743 \\
\cline { 2 - 7 } & LR & 0.7020 & 0.7216 & 0.7638 & 0.5518 \\
\hline
\end{tabular}


Correlation of PM emissions with fuel properties:

- Sulfur did not show any significant dhanges on PM on both engines due to lower content in sulfur levels of fuels tested which is evident from correlation coefficients between sulfur and PM shown in Table 6-2. The modern engine was a little more sensitive to sulfur changes where as the older engine showed no effect at all. However it is noted that the sulfur level at the fuels tested were all less than 500 ppm.

- Polyaromatics proved to be an influential property on PM in the modern engine when compared to the older engine which can be seen from the correlation coefficients seen in Table 6-2.

- Carbon played a crucial role in influencing PM as seen from the correlation coefficients for both the engines in Table 6-2.

Table 6-2 Correlation Coefficients between Fuel Properties and PM

\begin{tabular}{|c|c|c|c|c|}
\hline \multicolumn{2}{|c|}{ Cummins } & Carbon & Polyaromatics & Sulfur \\
\hline \multirow{2}{*}{ PM } & PCC & 0.9261 & 0.8030 & 0.354 \\
\cline { 2 - 5 } & LR & 0.8577 & 0.6448 & 0.1255 \\
\hline \multicolumn{2}{|c|}{ DDC } & Carbon & Polyaromatics & Sulfur \\
\hline \multirow{2}{*}{ PM } & PCC & 0.870 & 0.401 & -0.100 \\
\cline { 2 - 5 } & LR & 0.7560 & 0.1605 & 0.0099 \\
\hline
\end{tabular}

Correlation of $\mathrm{HC}$ emissions with fuel properties:

- HC was influenced by fuel properties of which the most effective fuel property was T50, which is evident from the correlation coefficients in Table 6-3. The modern engine showed a better sensitivity to T50 when compared to older engine.

Table 6-3 Correlation Coefficients between HC and T50

\begin{tabular}{|c|c|c|}
\hline \multicolumn{2}{|c|}{ Cummins } & T50 \\
\hline \multirow{2}{*}{ HC } & PCC & -0.8890 \\
\cline { 2 - 4 } & LR & 0.7903 \\
\hline \multicolumn{2}{|c|}{ DDC } & T50 \\
\hline \multirow{2}{*}{ HC } & PCC & -0.333 \\
\cline { 2 - 3 } & LR & 0.1111 \\
\hline
\end{tabular}


All of the fuel properties that affected emissions did not affect both engines equally as seen from the correlation and testing results obtained. However, three properties were affective on emissions for both the engines of which the NOx emissions had three properties that were common and included density, viscosity and polyaromatics. Both the engines were sensitive to carbon content in the fuel that had an effect on PM.

The mathematical model equations were derived in this study that predict the $\mathrm{HC}$, NOx and PM emissions based on some fuel properties. Predicted emissions from the models were close to the measured emissions and are engine specific only and do not represent universal equations that can be used for all engines.

Alternative fuels like biodiesel blends, B20, have a beneficial impact on emissions like $\mathrm{HC}, \mathrm{CO}$ and PM where as the NOx emissions increased by 5\% to 6\%, which may be attributed due to oxygen content in the biodiesel. However, the B20 blend associated well with the No.2 diesel fuel seen from the comparisons made which showed lower emissions and with changes to its fuel properties may even become more commonly used commercial diesel fuel in the near future.

The recommendations made for this study are as follows

- Testing wider range of diesel fuels which include summer and winter blends (which differ in energy content) from various locations in the US

- Examining the effect of the engine map being used for setpoints in certification of fuels

- Testing different biodiesel sources like plant, animal extract and processing to examine engine emissions

- Effect of adding additives like natural (hexadecane) and cetane boosters (2EHN) on regulated emissions

- Engine manufacturers equipping engines with on-board diagnostics (OBD) to monitor furl properties to enable in deciding control strategy being used

- Impact of fuel properties on aftertreatment devices (DPF, SCR, $\mathrm{NO}_{\mathrm{x}}$ Absorber,etc.) 


\section{REFERENCES}

1. Emission Standards, http://www.dieselnet.com/standards.html\#na, Ecopoint Inc., 2006.

2. Gautam, M., Clark, N. N., Thompson, G. J., and Lyons, D. W., "Assessment of Mobile Monitoring Technologies for Heavy-Duty Vehicle Emissions," White paper Submitted to the Settling Heavy-Duty Diesel Engine Manufacturers, Department of Mechanical and Aerospace Engineering, West Virginia University, Morgantown, WV, 1999.

3. Gautam, M., Clark, N. N., Thompson, G. J., Carder, and D. K., and Lyons, D. W., "Evaluation of Mobile Monitoring Technologies for Heavy-Duty Diesel-Powered Vehicle Emissions," Department of Mechanical and Aerospace Engineering, West Virginia University, Morgantown, WV, 2000.

4. Riddle, W. C., "Design and Evaluation of the Emissions Measurement Components for a Heavy-Duty Diesel Powered Vehicle Mobile Emissions Measurement System (MEMS)," M.S. Thesis, Department of Mechanical and Aerospace Engineering, West Virginia University, Morgantown, WV, 2001.

5. Gibble, J. C., "Comparison of Heavy-Duty Engine Emissions Between an On-Road Route and Engine Dynamometer Simulated On-Road Cycle," M.S. Thesis, Department of Mechanical and Aerospace Engineering, West Virginia University, Morgantown, WV, 2003.

6. Broering, L. C. and Holtman, L. W., "Effect of Diesel Fuel Properties on Emissions and Performance," SAE Technical Paper No. 740692, Warrendale PA, 1974.

7. Owen, K. and Coley, T., "Automotive Fuels Reference Book," Second Edition, SAE Publications, Warrendale, PA, 1995.

8. Diesel Fuels Technical Review (FTR-2), Chevron Products Company, 1998.

9. Hare, C.T. and Bradow, R.L., "Characterization of Heavy-Duty Diesel Gaseous and Particulate Emissions and Effects of Fuel Composition," SAE Technical Paper No.790490, Warrendale, PA, 1979. 
10. Baranescu, R., "Influence of Fuel Sulfur on Diesel Particular Emissions," SAE Technical Paper No. 881174, Warrendale, PA, 1988.

11. Ullman, T. L., 'Investigation of the Effects of Fuel Composition on Heavy-Duty Diesel Engine Emission," SAE Technical Paper No. 892072, Warrendale, PA, 1989.

12. Lange, W. W., "The Effect of Fuel Properties on Particulates Emissions in Heavy-Duty Truck Engines under Transient Operating Conditions," SAE Technical Paper No. 912425 , Warrendale, PA, 1991.

13. McCarthy, C. I., Slodowske, W. J., Sienicki, E. J., Jass and R. E., "Diesel Fuel Property Effects on Exhaust Emissions from a Heavy Duty Diesel Engine that Meets 1994 Emissions Requirements," SAE Technical Paper No. 922267, Warrendale, PA, 1992.

14. Den Ouden, C., Clark, R., Cowley, L. and Stradling, J., "Fuel Quality Effects on Particulate Matter Emissions from Light- and Heavy-Duty Diesel Engines," SAE Technical Paper No. 942022, Warrendale, PA, 1994.

15. Virk, K. S. and Lachowicz, D. R., "Testing of Diesel Fuels for Their Effects on Exhaust Emissions and Engine Performance," SAE Technical Paper No. 952362, Warrendale, PA, 1995.

16. Singal, S. K. and Pundir, B. P., "Diesel fuel quality and particulate emissions: An overview," SAE Technical Paper No. 961185, Warreandale, PA, 1996.

17. Nylund, N., Aakka, P., Mikkonen, S., and Niemi, A., "Effects of Physical and Chemical Properties of Diesel Fuel on $\mathrm{NO}_{\mathrm{x}}$ Emissions of Heavy-Duty Diesel Engines," SAE Technical Paper No. 972997, Warrendale, PA, 1997.

18. Clark, N. N., Atkinson, C. M., Thompson, G J. and Nine, R. D., “Transient Emissions Comparisons of Alternative Compression Ignition Fuels," SAE Technical Paper No. 1999-01-1117, Warrendale, PA, 1999.

19. Atkinson, C. M., Thompson, G. J., Traver, M. L. and Clark, N. N., "In-Cylinder Combustion Pressure Characteristics of Fischer-Tropsch and Conventional Diesel Fuels in a Heavy Duty CI Engine," SAE Technical Paper No. 1999-02-1472, Warrendale, PA, 1999. 
20. Kidoguchi, Y., Yang, C., and Miwa, K., 'Effects of Fuel Properties on Combustion and Emissions Characteristics of a Direct-injection Diesel Engine," SAE Technical Paper No. 2000-01-1851, Warrendale, PA, 2000.

21. Morita, A., and Sugiyama, G., "Influence of Density and Viscosity of Diesel Fuel on Exhaust Emissions," SAE Technical Paper No. 2003-01-1869, Warrendale, PA, 1992.

22. "Code of Federal Regulations," CFR 40 Part 86, Office of the Federal Register National Archives and Records Administration, Washington, D.C., 1994.

23. Pei, Y., "Development of Software for the Heavy-Duty Engine Testing at Engine Research Center, West Virginia University," M.S. Thesis, Department of Mechanical and Aerospace Engineering, West Virginia University, Morgantown, WV, 1993.

24. http://www.dieselnet.com/standards/cycles/ftp_trans.html

25. Jayasinghe, D., "Effects of Duty Cycles on Engine Design Parameters," M.S. Thesis, Department of Mechanical and Aerospace Engineering, West Virginia University, Morgantown, WV, 2006.

26. Haywood, John B., Internal Combustion Engine Fundamentals, McGraw-Hill, New York, NY, 1998.

27. Baert, R. S. G., Beckman, D. E., and Veen, A., "Efficient EGR Technology for Fut ure HD Diesel Engine Emissions Targets,” Technical Paper No. SAE 1999-01-0837, Warrendale, PA, 1999.

28. Sienicki, E. J., Jass, R. E., and Slodowske, W. J., "Diesel Fuel Aromatic and Cetane Number Effects on Combustion and Emissions from a Prototype 1991 Diesel Engine," SAE Technical Paper No. 902172, Warrendale, PA, 1990.

29. Signer, M., Heinze, P., Mercogliano, R., and Stein, H. J., "European Programme on Emissions, Fuels and Engine Technologies (EPEFE) - Heavy Duty Diesel Study," SAE Technical Paper No. 961074, Warrendale, PA, 1996.

30. Den Ouden, C. J. J., Clark, R. H., Cowley, L. T., Straddling, R. J., Lange, W. W., and Maillard, "Fuel Quality Effects on Particulate Matter Emissions from Light and Heavy Duty Diesel Engines," SAE Technical Paper No. 971636, Warrendale, PA, 1997. 
31. McCarthy, C. I., Slodowske, W. J., Sienicki, E. J., and Jass, R. E, "Diesel Fuel Property Effects on Exhaust Emissions From a Heavy Duty Diesel Engine that Meets 1994 Emissions Requirement," SAE Technical Paper No. 922267, Warrendale, PA, 1992.

32. Wall, J. C., Shimpi, S. A., and Yu, M. L., "Fuel Sulfur reduction for Control of Diesel Particulate emissions," SAE Technical Paper No. 872139, Warrendale, PA, 1987.

33. Ullman, T. L., Spreen, K. B. and Mason, R. L., "Effects of Cetane Number, Cetane Improver, Aromatics and Oxygenates on 1994 Heavy Duty Diesel Engine Emissions," SAE Technical Paper No. 941020, Warrendale, PA, 1994.

34. Cowley, L. T., Straddling, R. J., and Doyon, J., "The Influence of Composition and Properties of Diesel Fuel On Particulate Emissions from Heavy Duty Diesel Engines," SAE Technical Paper No. 932732, Warrendale, PA, 1993.

35. Wall, J. C. and Hoekman, S. K., "Fuel Composition Effects on Heavy Duty Diesel Particulate Emissions," SAE Technical Paper No. 841364, Warrendale, PA, 1984.

36. Morita, A. and Suglyama, G., "Influence of Density and Viscosity of Diesel Fuel on Exhaust Emissions," SAE Technical Paper No. 2003-01-1869, Warrendale, PA, 2003.

37. Ullman, T. L., Mason, R. L., and Montalvo, D. A., "Effects of Aromatics, Cetane Number and Cetane Improver on Emission from a Prototype 1991 Diesel Engine," SAE Technical Paper No. 902171, Warrendale, PA, 1990.

38. Ullman, T. L., Spreen, K. B., and Mason, R. L., "Effects of Cetane Number, Cetane Improver, Aromatics and Oxygenates on 1994 Heavy Duty Diesel Engine with Exhaust Catalyst," SAE Technical Paper No. 950250, Warrendale, PA, 1995.

39. Jacobs, T., Assanis, D., and Filipi, Z., 'The Impact of Exhaust Gas Recirculation on Performance and Emissions of A Heavy Duty Diesel Engine," SAE Technical Paper No. 2003-01-1068, Warrendale, PA, 2003.

40. Graboski, M. S., Ross, J. D., and Mccormick, R. L., 'Transient Emissions from No.2 Diesel and Biodiesel Blends in a DDC Series 60 Engine," SAE Technical Paper No. 961166, Warrendale, PA, 1996. 


\section{APPENDIX A}

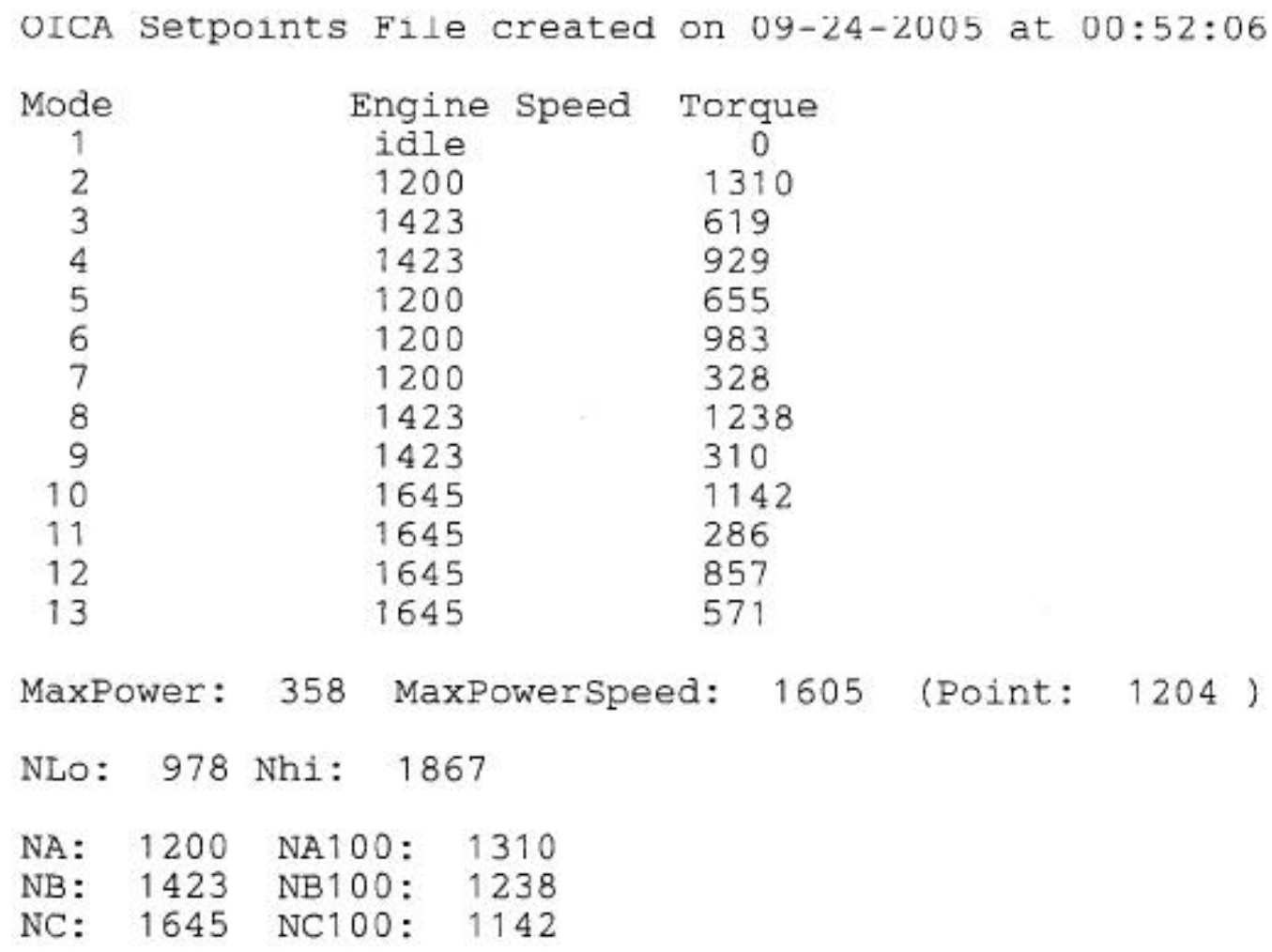




\section{APPENDIX B}

Table B Variation Analysis of Fuels

\begin{tabular}{|l|c|c|c|}
\hline \multicolumn{1}{|c|}{ Property } & Average & $\begin{array}{c}\text { Standard } \\
\text { Deviation }\end{array}$ & $\begin{array}{c}\text { Coefficient } \\
\text { of Variance }\end{array}$ \\
\hline Sulfur (ppm) & 328.3 & 103.3 & 31.5 \\
\hline Specific Gravity & 0.837 & 0.019 & 2.2 \\
\hline API Gravity & 37.6 & 3.8 & 10.1 \\
\hline $\begin{array}{l}\text { Kinematic viscosity @ } \\
40^{\circ} \text { C(cST) }\end{array}$ & 2.501 & 0.228 & 9.1 \\
\hline Carbon & 86.07 & 1.05 & 1.2 \\
\hline Hydrogen & 13.37 & 0.54 & 4.0 \\
\hline Nitrogen (ppm) & 132.3 & 150.6 & 113.9 \\
\hline Total Aromatics & 22.5 & 10.2 & 45.3 \\
\hline Mono Aromatics & 16.8 & 6.9 & 41.2 \\
\hline Polyaromatics & 5.7 & 4.0 & 70.0 \\
\hline Cetane Number & 52.0 & 7.6 & 14.6 \\
\hline Flash point (F) & 149.9 & 9.6 & 6.4 \\
\hline Distillation, ( ${ }^{\circ}$ F) IBP & 342.0 & 12.7 & 3.7 \\
\hline $5 \%$ & 380.4 & 13.6 & 3.6 \\
\hline $10 \%$ & 396.8 & 19.2 & 4.8 \\
\hline $15 \%$ & 410.0 & 21.1 & 5.2 \\
\hline $20 \%$ & 422.4 & 22.2 & 5.2 \\
\hline $30 \%$ & 447.6 & 21.6 & 4.8 \\
\hline $40 \%$ & 473.5 & 19.5 & 4.1 \\
\hline $50 \%$ & 499.1 & 17.5 & 3.5 \\
\hline $60 \%$ & 524.6 & 16.3 & 3.1 \\
\hline $70 \%$ & 550.6 & 14.5 & 2.6 \\
\hline $80 \%$ & 577.4 & 12.7 & 2.2 \\
\hline $90 \%$ & 608.8 & 12.3 & 2.0 \\
\hline $95 \%$ & 632.3 & 15.5 & 2.4 \\
\hline FBP & 650.9 & 18.7 & 2.9 \\
\hline Recovered & 97.9 & 0.5 & 0.5 \\
\hline Loss & 1.1 & 0.3 & 24.4 \\
\hline Residue & 1.0 & 0.4 & 41.7 \\
\hline
\end{tabular}




\section{APPENDIX C}

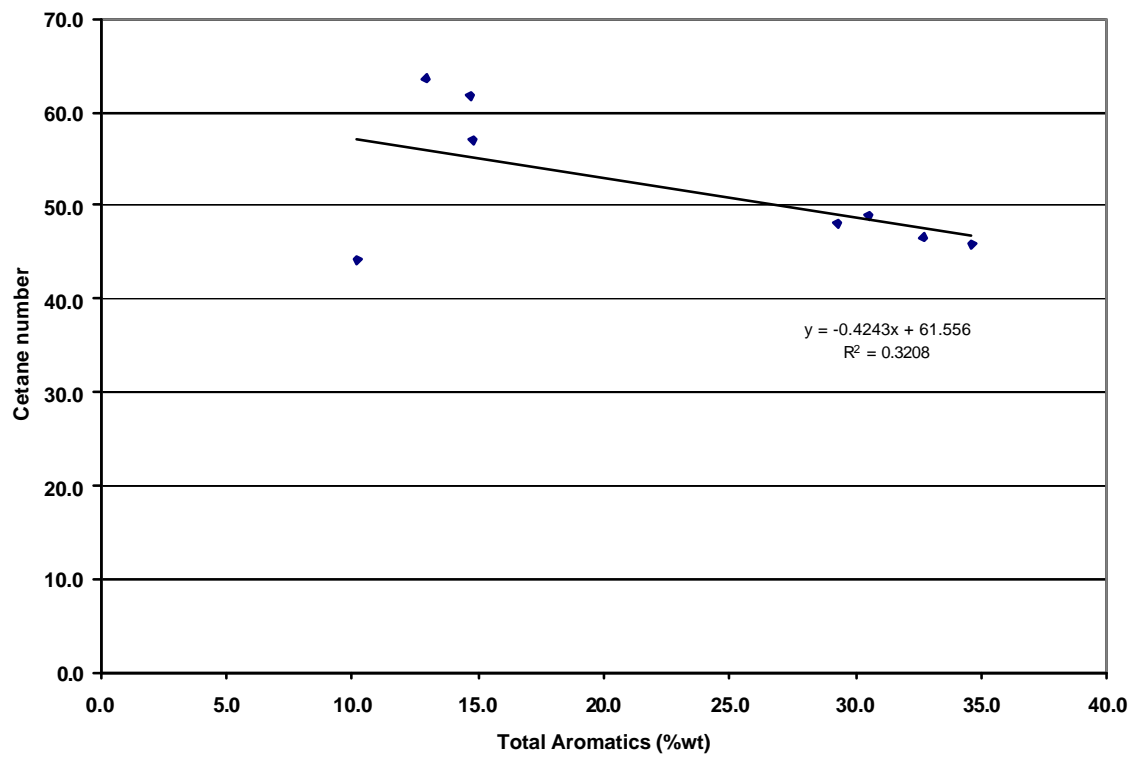

Figure C Cetane Number Versus Total Aromatics 


\section{APPENDIX D}

Table D-1 Cummins FTP Data

\begin{tabular}{|c|c|c|c|c|c|c|c|c|c|c|c|c|c|c|c|c|c|c|}
\hline Fuel & & & Sabrato & roger & & & & & Guttma & an-1 & & & & & Shell E & rsfield & & \\
\hline StartType & Hot Start & Hot Start & Hot Start & Average & \begin{tabular}{|l|} 
Standard \\
Deviation \\
\end{tabular} & COV & Hot Start & Hot Start & Hot Start & Average & \begin{tabular}{|l|} 
Standard \\
Deviation
\end{tabular} & $\mathrm{COV}$ & Hot Start & Hot Start & Hot Start & Average & \begin{tabular}{|l|} 
Standard \\
Deviation \\
\end{tabular} & $\mathrm{COV}$ \\
\hline Actual work (bhp-hr) & 25.92 & 25.92 & 25.92 & 25.92 & 0.00 & 0.00 & 24.54 & 24.57 & 24.55 & 24.55 & 0.02 & 0.06 & 5.54 & 25.53 & 25.51 & 25.53 & 0.02 & 0.06 \\
\hline BSFC (lb/bhp-hr) & 0.413 & 0.413 & 0.413 & 0.413 & 0.000 & 0.078 & 0.412 & 0.412 & 0.412 & 0.412 & 0.000 & 0.070 & 0.411 & 0.411 & 0.412 & 0.411 & 0.000 & 0.028 \\
\hline Fuel consumption (lb) & 10.70 & 10.70 & 10.72 & 10.71 & 0.01 & 0.08 & 10.11 & 10.12 & 10.10 & 10.11 & 0.01 & 0.09 & 10.50 & 10.50 & 10.50 & 10.50 & 0.00 & 0.03 \\
\hline Fuel recovered (lb) & 10.461 & 10.474 & 10.455 & 10.463 & 0.010 & 0.093 & 9.844 & 9.874 & 9.864 & 9.861 & 0.015 & 0.155 & 10.226 & 10.223 & 10.181 & 10.210 & 0.025 & 0.246 \\
\hline $\mathrm{HC}$ (g/bhp-hr) & 182 & 0.185 & 0.184 & 0.184 & 0.002 & 0.861 & 0.195 & 0.199 & 0.204 & 0.199 & 0.004 & 2.139 & 0.198 & 0.202 & 0.202 & 0.201 & 0.002 & 1.209 \\
\hline $\mathrm{CO}$ (g/bhp-hr) & 0.613 & 0.611 & 0.593 & 0.606 & 0.011 & 1.819 & 0.531 & 0.545 & 0.545 & 0.540 & 0.008 & 1.496 & 0.621 & 0.625 & 0.618 & 0.621 & 0.004 & 0.565 \\
\hline CO2 (g/bhp-hr) & 582.7 & 583.4 & 582.3 & 582.8 & 0.6 & 0.1 & 570.6 & 571.7 & 571.4 & 571.3 & 0.6 & 0.1 & 572.9 & 572.9 & 570.9 & 572.2 & 1.1 & 0.2 \\
\hline NOx (g/bhp-hr) & 2.295 & 2.298 & 2.294 & 2.296 & 0.002 & 0.091 & 2.093 & 2.103 & 2.108 & 2.101 & 0.008 & 0.363 & 2.158 & 2.164 & 2.161 & 2.161 & 0.003 & 0.139 \\
\hline NOx2 (g/bhp-hr) & 2.310 & 2.311 & 2.312 & 2.311 & 0.001 & 0.043 & 2.132 & 2.115 & 2.124 & 2.124 & 0.009 & 0.400 & 2.168 & 2.175 & 2.168 & 2.170 & 0.004 & 0.186 \\
\hline PM (g/bhp-hr) & 0.072 & 0.070 & 0.069 & 0.070 & 0.001 & 1.957 & 0.061 & 0.061 & 0.062 & 0.061 & 0.000 & 0.348 & 0.058 & 0.061 & 0.061 & 0.060 & 0.002 & 2.958 \\
\hline TEOM & 0.051 & 0.050 & 0.050 & 0.050 & 0.000 & 0.644 & 0.040 & 0.042 & 0.042 & 0.041 & 0.001 & 2.965 & 0.039 & 0.041 & 0.042 & 0.040 & 0.002 & 3.860 \\
\hline Average humidity factor & 1.023 & 1.022 & 1.023 & 1.023 & 0.001 & 0.056 & 1.009 & 1.012 & 1.014 & 1.012 & 0.003 & 0.249 & 1.007 & 1.009 & 1.013 & 1.010 & 0.003 & 0.303 \\
\hline Average relative humidity (\%) & 53.52 & 53.81 & 54.17 & 53.83 & 0.33 & 0.60 & 53.44 & 53.05 & 52.52 & 53.00 & 0.46 & 0.87 & 50.45 & 51.08 & 51.40 & 50.98 & 0.48 & 0.95 \\
\hline $\begin{array}{l}\text { Intake absolute humidity } \\
\text { (grain/lb) }\end{array}$ & 83.54 & 83.32 & 83.80 & 83.55 & 0.24 & 0.29 & 78.58 & 79.51 & 80.19 & 79.43 & 0.81 & 1.02 & 77.80 & 78.45 & 79.75 & 78.67 & 0.99 & 1.26 \\
\hline
\end{tabular}


Table D-2 Cummins FTP Data

\begin{tabular}{|c|c|c|c|c|c|c|c|c|c|c|c|c|c|c|c|c|c|c|}
\hline tel & \multicolumn{6}{|c|}{ CEDC1 } & \multicolumn{6}{|c|}{ Sabraton Sheetz } & \multicolumn{6}{|c|}{ Mileground $\mathrm{BP}$} \\
\hline StartType & $\begin{array}{l}\text { Hot } \\
\text { Start }\end{array}$ & $\begin{array}{l}\text { Hot } \\
\text { Start }\end{array}$ & Hot St & Average & \begin{tabular}{|l|} 
Standard \\
Deviation
\end{tabular} & $\mathrm{COV}$ & Hot Start & Hot Start & $\begin{array}{l}\text { Hot } \\
\text { Start }\end{array}$ & Average & \begin{tabular}{|l|} 
Standard \\
Deviation
\end{tabular} & COV & $\begin{array}{l}\text { Hot } \\
\text { Start }\end{array}$ & $\begin{array}{l}\text { Hot } \\
\text { Start }\end{array}$ & t Start & Average & \begin{tabular}{|l|} 
Standard \\
Deviation
\end{tabular} & $\mathrm{COV}$ \\
\hline Actual work (bhp-hr & 25.26 & 25.24 & 25.24 & 25.25 & 0.01 & 0.05 & 25.99 & 25.98 & 25.97 & 25.98 & 0.01 & 0.04 & 25.73 & 25.71 & 25.71 & 25.72 & 0.01 & 0.04 \\
\hline BSFC (b/bhp-hr) & 416 & 0.415 & 0.417 & 0.416 & 0.001 & 0.227 & 0.415 & 0.414 & 0.414 & 0.415 & 0.001 & 0.153 & 0.415 & 0.415 & 0.412 & 0.414 & 0.002 & 0.366 \\
\hline Fuel consumption & 10.51 & 10.47 & 10.52 & 10.50 & 0.03 & 0.24 & 10.80 & 10.76 & 10.76 & 10.77 & 0.02 & 0.19 & 10.68 & 10.66 & 10.60 & 10.64 & 0.04 & 0.39 \\
\hline uel recov & 10.07 & 10.08 & 10.10 & 10.08 & 0.02 & 0.19 & 10.49 & 10.50 & 10.50 & 10.50 & 0.01 & 0.06 & 10.29 & 10.28 & 10.31 & 10.29 & 0.01 & 0.12 \\
\hline & & & & & & & & & & & & & & & & & & \\
\hline$(\mathrm{g} / \mathrm{bh}$ & .185 & 0.185 & 0.193 & 0.188 & 0.005 & 2.437 & 0.179 & 0.181 & 0.183 & 0.181 & 0.002 & 0.899 & 0.189 & 0.190 & 0.191 & 0.190 & 0.001 & 0.583 \\
\hline $\mathrm{CO}$ (g/bhp-hr) & 0.545 & 0.545 & 0.555 & 0.548 & 0.006 & 1.053 & 0.587 & \begin{tabular}{|l|}
0.571 \\
\end{tabular} & 0.563 & 0.574 & 0.012 & 2.130 & 0.572 & 0.577 & 0.565 & 0.571 & 0.006 & 1.055 \\
\hline CO2 (g/bhp-hr) & 573.2 & 573.9 & 575.6 & 574.3 & 1.2 & 0.2 & 581.7 & 582.5 & 583.0 & \begin{tabular}{|l|}
582.4 \\
\end{tabular} & 0.7 & 0.1 & 577.9 & 577.9 & 579.2 & 578.3 & 0.7 & 0.1 \\
\hline NOx (g/bhp-hr) & 2.145 & 2.159 & 2.144 & 2.149 & 0.008 & 0.390 & 2.294 & 2.287 & 2.288 & 2.290 & 0.004 & 0.165 & 2.259 & 2.255 & 2.263 & 2.259 & 0.004 & 0.177 \\
\hline NOx2 (a/bhp-hr) & 2.154 & 2.168 & 2.160 & 2.161 & 0.007 & 0.325 & 2.284 & 2.295 & 2.309 & 2.296 & 0.013 & 0.546 & 2.290 & 2.291 & 2.297 & 2.293 & 0.004 & 0.165 \\
\hline PM (g/bhp-hr) & 0.058 & 0.062 & 0.061 & 0.060 & 0.002 & 3.046 & 0.074 & 0.074 & 0.074 & \begin{tabular}{|l|}
0.074 \\
\end{tabular} & 0.000 & 0.605 & 0.071 & 0.073 & 0.073 & 0.072 & 0.001 & 1.236 \\
\hline & & & & & & & & & & & & & & & & & & \\
\hline EOM & 0.039 & 0.041 & 0.041 & 0.040 & 0.001 & 3.272 & 0.051 & 0.051 & 0.052 & 0.052 & 0.001 & 1.346 & 0.046 & 0.048 & 0.047 & 0.047 & 0.001 & 1.996 \\
\hline rage & 1008 & 1021 & & & & $2 ? 2$ & & $01 \mathrm{~h}$ & & 012 & 0004 & 431 & 006 & 1006 & 208 & 007 & 001 & 115 \\
\hline rage & 51.54 & 51.46 & 53.38 & \begin{tabular}{|l|}
52.13 \\
\end{tabular} & 1.09 & 2.08 & 51.49 & 50.83 & 49.64 & \begin{tabular}{|l}
1.60 .65 \\
\end{tabular} & 0.94 & \begin{tabular}{|l|}
0.701 \\
1.85 \\
\end{tabular} & 52.88 & 52.37 & 52.44 & 52.56 & $\frac{0.001}{0.28}$ & \begin{tabular}{|l}
0.115 \\
0.53
\end{tabular} \\
\hline $\begin{array}{l}\text { take absolute humidity } \\
\text { yrain/lb) }\end{array}$ & 78.13 & 83.06 & 88.08 & 83.09 & 4.97 & 5.98 & 80.19 & 80.76 & 77.49 & 79.48 & 1.75 & 2.20 & 77.27 & 77.30 & 78.18 & 77.58 & 0.52 & 0.67 \\
\hline
\end{tabular}


Table D-3 Cummins FTP Data

\begin{tabular}{|c|c|c|c|c|c|c|c|c|c|c|c|c|}
\hline Fuel & \multicolumn{6}{|c|}{ Guttman-2 } & \multicolumn{6}{|c|}{ B20 } \\
\hline StartType & $\begin{array}{l}\text { Hot } \\
\text { Start }\end{array}$ & $\begin{array}{l}\text { Hot } \\
\text { Start }\end{array}$ & Hot Start & Average & $\begin{array}{l}\text { Standard } \\
\text { Deviation }\end{array}$ & COV & Hot Start & Hot Start & $\begin{array}{l}\text { Hot } \\
\text { Start }\end{array}$ & Average & \begin{tabular}{|l|} 
Standard \\
Deviation
\end{tabular} & $\mathrm{COV}$ \\
\hline Actual work (bhp-hr) & 24.50 & 24.51 & 24.51 & 24.51 & 0.01 & 0.02 & 24.41 & 24.36 & 24.36 & 24.3767 & \begin{tabular}{|l|}
0.02887 \\
\end{tabular} & 0.118 \\
\hline BSFC (Ib/bhp-hr) & 0.413 & 0.413 & 0.413 & 0.413 & 0.000 & 0.024 & 0.4274 & 0.4259 & 0.425 & 0.4261 & 0.00121 & 0.285 \\
\hline Fuel consumption (lb) & 10.12 & 10.12 & 10.12 & 10.12 & 0.00 & 0.01 & 10.436 & 10.375 & 10.352 & 10.3877 & 0.04341 & 0.418 \\
\hline Fuel recovered (lb) & 10.02 & 10.01 & 9.80 & 9.94 & 0.12 & 1.24 & 10.128 & 10.087 & 10.065 & 10.0933 & 0.03197 & 0.317 \\
\hline $\mathrm{HC}$ (g/bhp-hr) & 0.197 & 0.202 & 0.197 & 0.199 & 0.003 & 1.437 & 0.1647 & 0.1672 & 0.1651 & 0.16567 & 0.00134 & 0.811 \\
\hline $\mathrm{CO}$ (g/bhp-hr) & 0.554 & 0.554 & 0.544 & 0.551 & 0.006 & 1.048 & 0.525 & 0.524 & 0.523 & 0.524 & 0.001 & 0.191 \\
\hline CO2 (g/bhp-hr) & 582.4 & 581.6 & 569.4 & 577.8 & 7.3 & 1.3 & 576.045 & 574.97 & 573.888 & 574.968 & 1.0785 & 0.188 \\
\hline NOx (g/bhp-hr) & 2.102 & 2.095 & 2.110 & 2.102 & 0.008 & 0.357 & 2.222 & 2.217 & 2.229 & 2.22267 & 0.00603 & 0.271 \\
\hline NOx2 (g/bhp-hr) & 2.113 & 2.108 & 2.140 & 2.120 & 0.017 & 0.812 & 2.25 & 2.25 & 2.25 & 2.25 & 0 & 0 \\
\hline PM (g/bhp-hr) & 0.062 & 0.063 & 0.062 & 0.062 & 0.000 & 0.750 & 0.04303 & 0.04522 & 0.04798 & 0.04541 & 0.00248 & 5.462 \\
\hline TEOM & 0.040 & 0.041 & 0.040 & 0.040 & 0.001 & 1.667 & 0.029 & 0.029 & 0.030 & 0.029 & 0.001 & 2.221 \\
\hline Average humidity factor & 1.009 & 1.014 & 1.024 & 1.016 & 0.008 & 0.752 & 1.016 & 1.018 & 1.021 & 1.018 & 0.003 & 0.247 \\
\hline Average relative humidity (\%) & 50.03 & 49.91 & 52.81 & 50.92 & 1.64 & 3.22 & 51.36 & 50.37 & 50.69 & 50.81 & 0.51 & 0.99 \\
\hline $\begin{array}{l}\text { Intake absolute humidity } \\
\text { (grain/lb) }\end{array}$ & 78.25 & 79.77 & 84.17 & 80.73 & 3.08 & 3.81 & 81.20 & 81.68 & 82.74 & 81.87 & 0.79 & 0.96 \\
\hline
\end{tabular}




\section{Table D-4 DDC FTP Data}

\begin{tabular}{|c|c|c|c|c|c|c|c|c|c|c|c|c|c|c|c|c|c|c|}
\hline Fuel & \multicolumn{6}{|c|}{ Guttman-1 } & \multicolumn{6}{|c|}{ Sabraton Kroger } & \multicolumn{6}{|c|}{ Mileground BP } \\
\hline StartType & $\begin{array}{l}\text { Hot } \\
\text { Start }\end{array}$ & $\begin{array}{c}\text { Hot } \\
\text { Start } \\
\end{array}$ & Hot Start & Average & \begin{tabular}{|l|} 
Standard \\
Deviation \\
\end{tabular} & COV & Hot Start & Hot Start & $\begin{array}{l}\text { Hot } \\
\text { Start }\end{array}$ & Average & \begin{tabular}{|l|} 
Standard \\
Deviation
\end{tabular} & COV & $\begin{array}{l}\text { Hot } \\
\text { Start }\end{array}$ & $\begin{array}{c}\text { Hot } \\
\text { Start }\end{array}$ & Hot Start & Average & \begin{tabular}{|l|} 
Standard \\
Deviation \\
\end{tabular} & COV \\
\hline Actual work (bhp-hr) & 23.22 & 23.22 & 23.17 & 23.20 & 0.03 & 0.1 & 24.83 & 23.17 & 23.20 & 23.73 & 0.95 & 4.0 & 24.58 & 24.57 & 24.56 & 24.57 & 0.01 & 0.0 \\
\hline BSFC (lb/bhp-hr) & 0.38 & 0.38 & 0.38 & 0.38 & 0.00 & 0.1 & 0.39 & 0.38 & 0.38 & 0.38 & 0.01 & 1.8 & 0.39 & 0.39 & 0.39 & 0.39 & 0.00 & 0.4 \\
\hline Fuel consumption (Ib) & 8.794 & 8.794 & 8.77 & 8.786 & 0.013856 & 0.2 & 9.696 & 8.77 & 8.783 & 9.083 & 0.53091 & 5.8 & 9.529 & 9.571 & 9.598 & 9.566 & 0.03477 & 0.4 \\
\hline Fuel recovered (b) & 8.487 & 8.487 & 8.464 & 8.479 & 0.013 & 0.2 & 9.167 & 8.464 & 8.464 & 8.698 & 0.406 & 4.7 & 9.039 & 9.003 & 9.035 & 9.026 & 0.020 & 0.2 \\
\hline & & & & & & & & & & & & & & & & & & \\
\hline HC (g/bhp-hr) & 0.1 & 0.1 & 0.1 & 0.1 & 0.0 & 4.5 & 0.1 & 0.1 & 0.1 & 0.1 & 0.0 & 8.2 & 0.1 & 0.1 & 0.1 & 0.1 & 0.0 & 0.7 \\
\hline CO (g/bhp-hr) & 2.488 & 2.488 & 2.502 & 2.493 & 0.008 & 0.3 & 3.027 & 2.502 & 2.510 & 2.680 & 0.301 & 11.2 & 2.839 & 2.815 & 2.891 & 2.848 & 0.039 & 1.4 \\
\hline CO2 (g/bhp-hr) & 517.2 & 517.2 & 516.6 & 517.0 & 0.3 & 0.1 & 529.3 & 516.6 & 516.1 & 520.7 & 7.5 & 1.4 & 527.9 & 526.1 & 527.9 & 527.3 & 1.1 & 0.2 \\
\hline NOx (g/bhp-hr) & 4.466 & 4.466 & 4.476 & 4.469 & 0.006 & 0.1 & 5.304 & 4.476 & 4.454 & 4.745 & 0.485 & 10.2 & 5.139 & 5.109 & 5.127 & 5.125 & 0.015 & 0.3 \\
\hline NOx2 (g/bhp-hr) & 4.477 & 4.477 & 4.494 & 4.48267 & 0.009815 & 0.2 & 5.3 & 4.494 & 4.468 & 4.754 & 0.47303 & 10.0 & 5.171 & 5.116 & 5.109 & 5.132 & 0.03396 & 0.7 \\
\hline PM (g/bhp-hr) & 0.205 & 0.205 & 0.213 & 0.208 & 0.005 & 2.2 & 0.228 & 0.213 & 0.216 & 0.219 & 0.008 & 3.6 & 0.222 & 0.222 & 0.230 & 0.225 & 0.005 & 2.1 \\
\hline & & & & & & & & & & & & & & & & & & \\
\hline TEOM & 0.157 & 0.157 & 0.163 & 0.159 & 0.004 & 2.4 & 0.169 & 0.163 & 0.167 & 0.166 & 0.003 & 1.7 & 0.164 & 0.160 & 0.167 & 0.163 & 0.004 & 2.2 \\
\hline & & & & & & & & & & & & & & & & & & \\
\hline Average humidity factor & 1.00 & 1.00 & 1.00 & 1.00 & 0.00 & 0.1 & 0.99 & 1.00 & 1.00 & 1.00 & 0.01 & 0.7 & 0.98 & 0.98 & 0.98 & 0.98 & 0.00 & 0.3 \\
\hline Average relative humidity (\%) & 52.96 & 52.96 & 52.78 & 52.90 & 0.10 & 0.2 & 51.01 & 52.78 & 52.28 & 52.02 & 0.91 & 1.8 & 49.49 & 49.53 & 50.29 & 49.77 & 0.45 & 0.9 \\
\hline \begin{tabular}{|l} 
Intake absolute humidity \\
(grain/lb)
\end{tabular} & 75.127 & 75.127 & 75.534 & 75.263 & 0.235 & 0.3 & 71.050 & 75.534 & 75.961 & 74.182 & 2.720 & 3.7 & 66.782 & 66.025 & 68.036 & 66.948 & 1.016 & 1.5 \\
\hline
\end{tabular}




\section{Table D-5 DDC FTP Data}

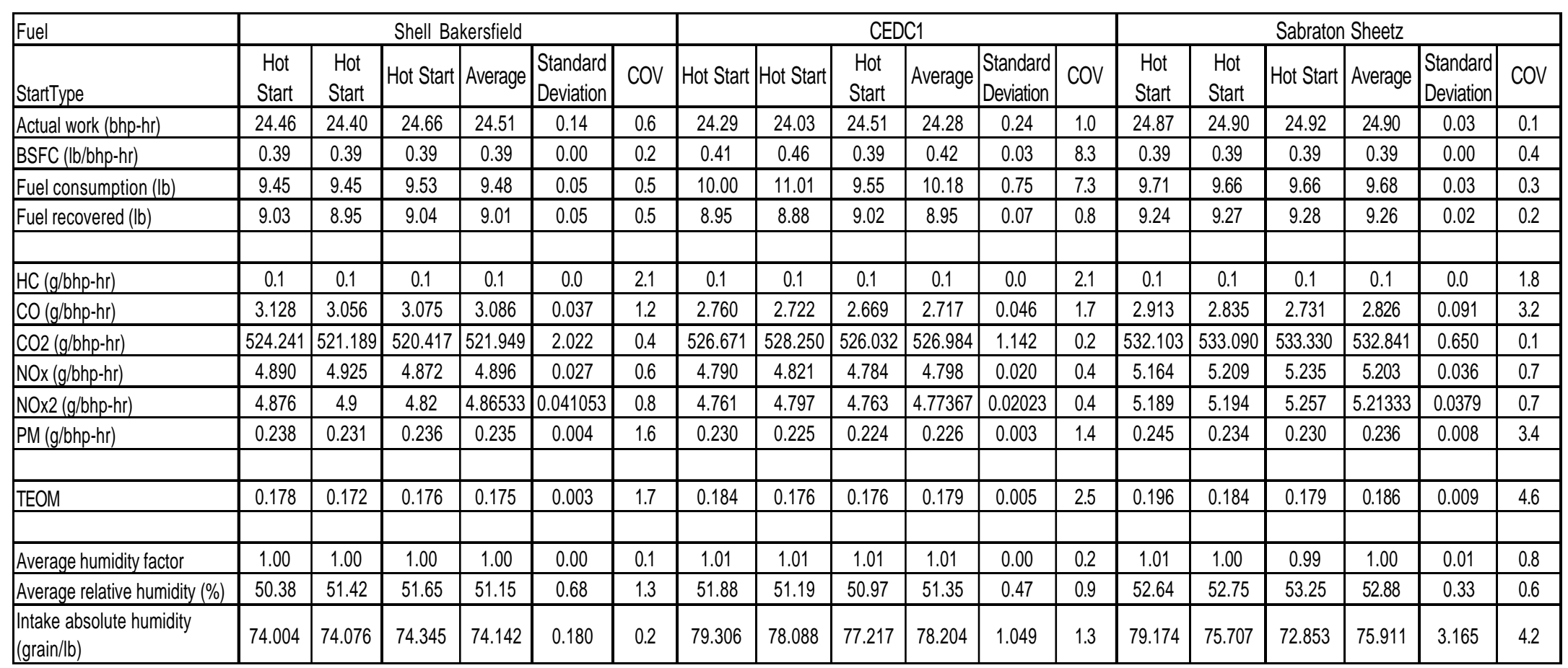


Table D-6 DDC FTP data

\begin{tabular}{|c|c|c|c|c|c|c|c|c|c|c|c|c|}
\hline \multirow{2}{*}{\begin{tabular}{|l} 
Fuel \\
StartType \\
\end{tabular}} & \multicolumn{6}{|c|}{ Guttman-2 } & \multicolumn{6}{|c|}{$\mathrm{B} 20$} \\
\hline & $\begin{array}{l}\text { Hot } \\
\text { Start }\end{array}$ & $\begin{array}{l}\text { Hot } \\
\text { Start }\end{array}$ & Hot Start & Average & \begin{tabular}{|l|} 
Standard \\
Deviation \\
\end{tabular} & COV & Hot Start & |Hot Start & $\begin{array}{l}\text { Hot } \\
\text { Start }\end{array}$ & Average & \begin{tabular}{|l|} 
Standard \\
Deviation \\
\end{tabular} & COV \\
\hline Actual work (bhp-hr) & 23.4 & 23.4 & 23.4 & 23.4 & 0.0 & 0.1 & 23.5 & 23.6 & 23.7 & 23.6 & 0.1 & 0.2 \\
\hline BSFC (Ib/bhp-hr) & 0.380 & 0.381 & 0.380 & 0.380 & 0.001 & 0.2 & 0.391 & 0.390 & 0.389 & 0.390 & 0.001 & 0.2 \\
\hline Fuel consumption (lb) & 8.896 & 8.905 & 8.883 & 8.895 & 0.011 & 0.1 & 9.190 & 9.194 & 9.190 & 9.191 & 0.002 & 0.0 \\
\hline Fuel recovered (Ib) & 8.718 & 8.709 & 8.904 & 8.777 & 0.110 & 1.3 & 9.055 & 9.065 & 9.059 & 9.060 & 0.005 & 0.1 \\
\hline & & & & & & & & & & & & \\
\hline $\mathrm{HC}(\mathrm{g} / \mathrm{bhp}-\mathrm{hr})$ & 0.096 & 0.093 & 0.098 & 0.096 & 0.002 & 2.6 & 0.084 & 0.091 & 0.089 & 0.088 & 0.004 & 4.1 \\
\hline $\mathrm{CO}$ (g/bhp-hr) & 2.613 & 2.578 & 2.646 & 2.612 & 0.034 & 1.3 & 2.320 & 2.304 & 2.275 & 2.300 & 0.023 & 1.0 \\
\hline CO2 (g/bhp-hr) & 527.1 & 527.6 & 539.2 & 531.3 & 6.8 & 1.3 & 531.6 & 530.9 & 529.3 & 530.6 & 1.2 & 0.2 \\
\hline NOx (g/bhp-hr) & 4.599 & 4.586 & 4.585 & 4.590 & 0.008 & 0.2 & 4.767 & 4.799 & 4.801 & 4.789 & 0.019 & 0.4 \\
\hline NOx2 (g/bhp-hr) & 4.649 & 4.675 & 4.645 & 4.656 & 0.016 & 0.3 & 4.815 & 4.857 & 4.837 & 4.836 & 0.021 & 0.4 \\
\hline PM (g/bhp-hr) & 0.224 & 0.227 & 0.227 & 0.226 & 0.002 & 0.9 & 0.173 & 0.174 & 0.170 & 0.172 & 0.002 & 1.2 \\
\hline TEOM & 0.169 & 0.172 & 0.178 & 0.173 & 0.005 & 2.7 & 0.139 & 0.140 & 0.141 & 0.140 & 0.001 & 0.6 \\
\hline & & & & & & & & & & & & \\
\hline Average humidity factor & 1.02 & 1.02 & 1.01 & 1.01 & 0.01 & 0.7 & 1.00 & 1.00 & 1.00 & 1.00 & 0.00 & 0.1 \\
\hline Average relative humidity (\%) & 56.38 & 57.17 & 55.09 & 56.21 & 1.05 & 1.9 & 51.31 & 51.90 & 51.85 & 51.69 & 0.33 & 0.6 \\
\hline $\begin{array}{l}\text { Intake absolute humidity } \\
\text { (grain/lb) }\end{array}$ & 81.49 & 82.339 & 82.752 & 82.1937 & 0.643 & 0.8 & 73.634 & 73.587 & 72.957 & 73.3927 & 0.378 & 0.5 \\
\hline
\end{tabular}




\section{APPENDIX E}

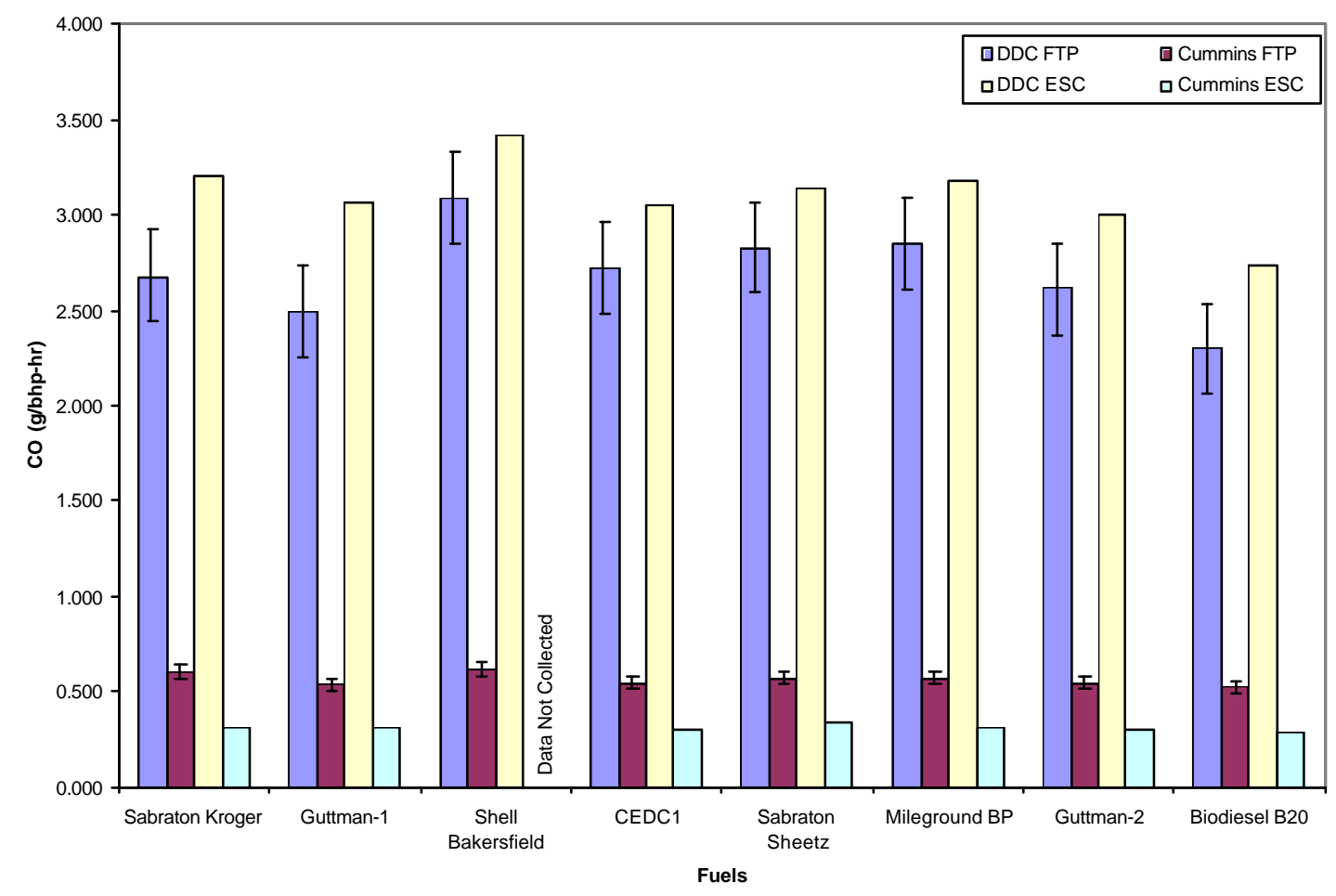

Figure E-1 Fuel Specific CO Emissions

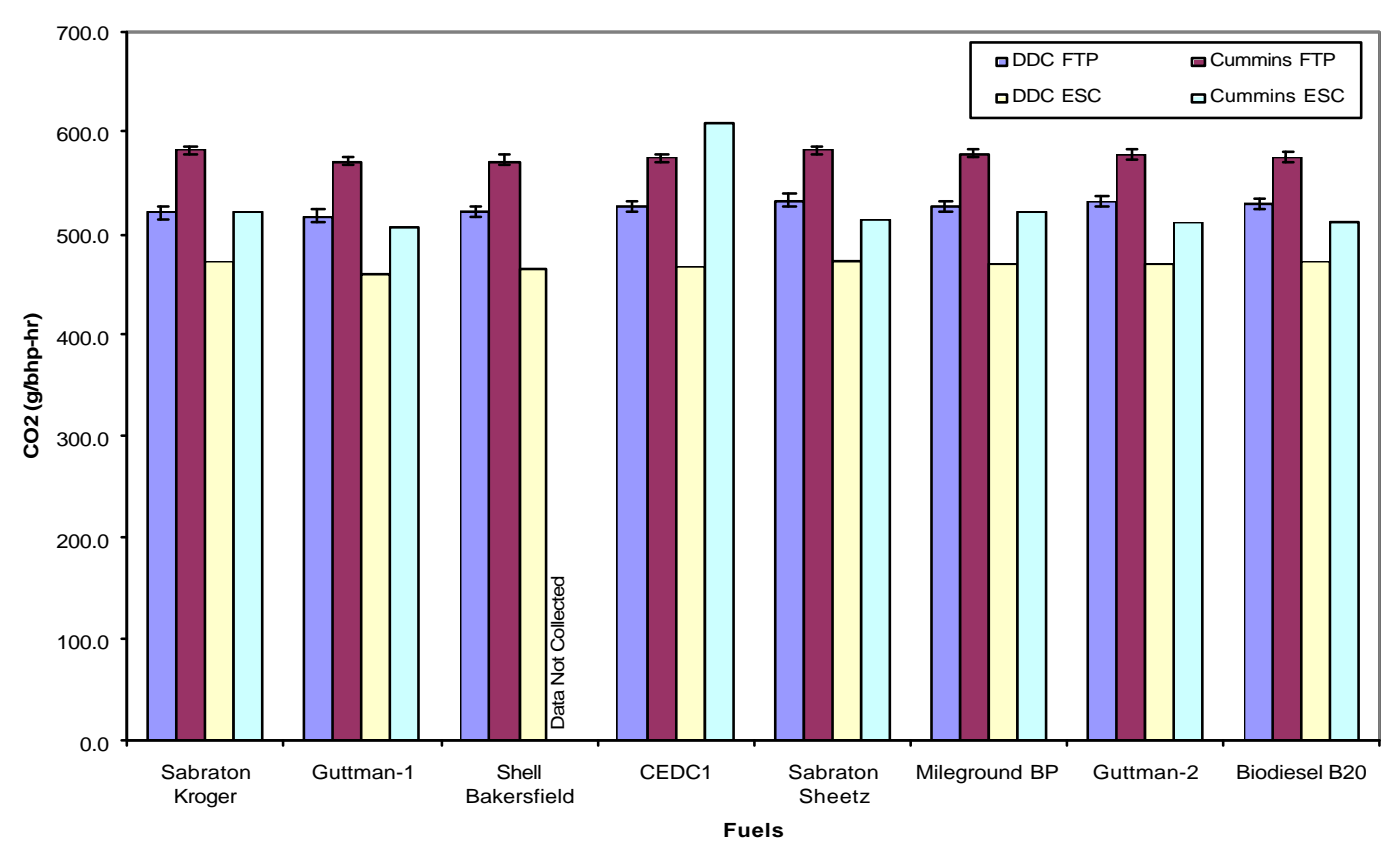

Figure D-1 Fuel Specific $\mathrm{CO}_{2}$ Emissions 


\section{APPENDIX F}

The GLM Procedure

$\begin{array}{ll}\text { Number of Observations Read } & 8 \\ \text { Number of Observations Used } & 8\end{array}$

Test1 analysis 23:17 Sunday, June 11, 20064

The GLM Procedure

Dependent Variable: Y1

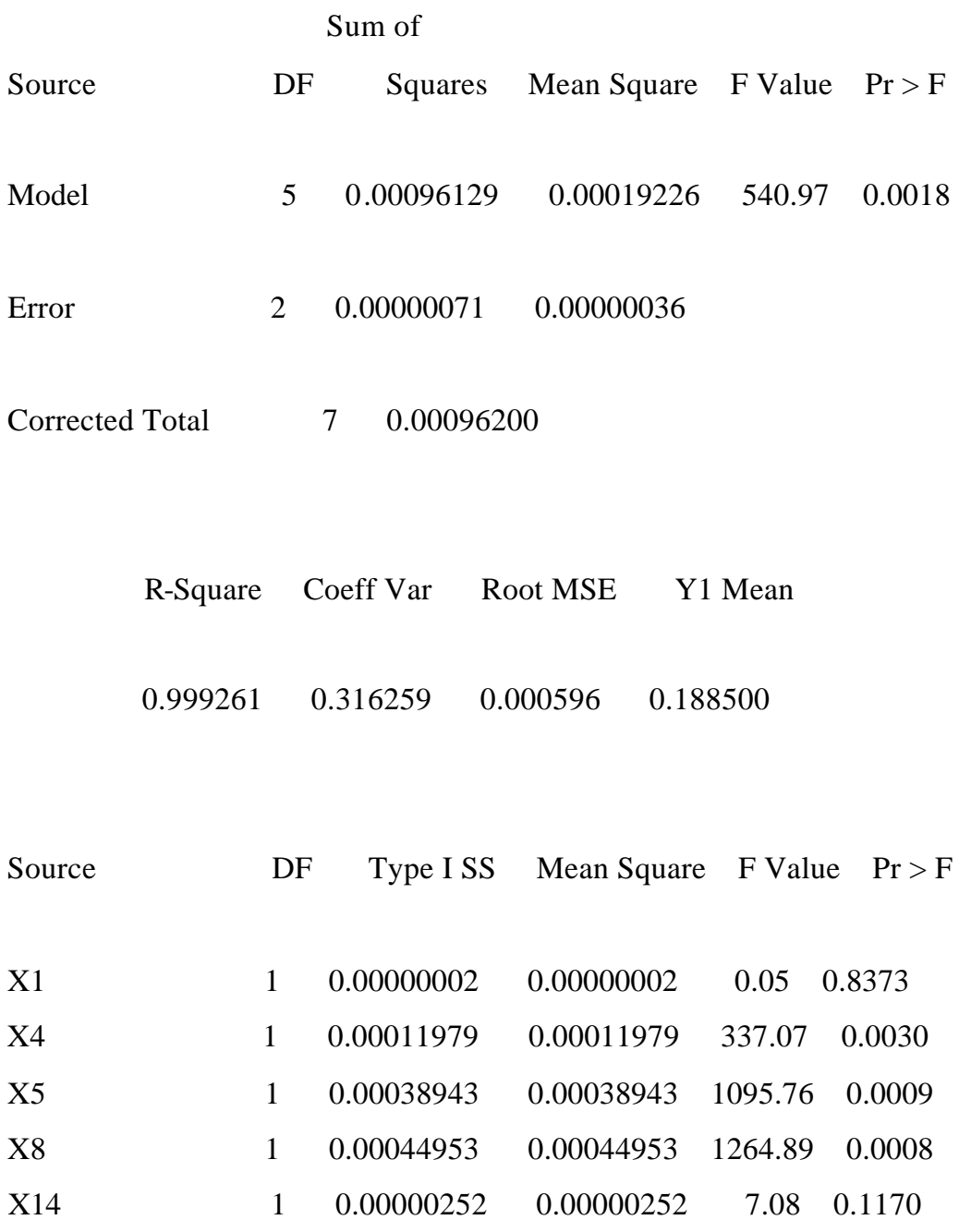




$\begin{array}{lccccc}\text { Source } & \text { DF } & \text { Type III SS } & \text { Mean Square } & \text { F Value } & \text { Pr }>\text { F } \\ & & & & & \\ \text { X1 } & 1 & 0.00000173 & 0.00000173 & 4.87 & 0.1580 \\ \text { X4 } & 1 & 0.00009496 & 0.00009496 & 267.20 & 0.0037 \\ \text { X5 } & 1 & 0.00078513 & 0.00078513 & 2209.18 & 0.0005 \\ \text { X8 } & 1 & 0.00040403 & 0.00040403 & 1136.85 & 0.0009 \\ \text { X14 } & 1 & 0.00000252 & 0.00000252 & 7.08 & 0.1170\end{array}$

\section{Standard}

Parameter Estimate Error $t$ Value $\operatorname{Pr}>|t|$

$\begin{array}{lllll}\text { Intercept } & -.8841417927 & 0.03085978 & -28.65 & 0.0012\end{array}$

$\begin{array}{llllll}\mathrm{X} 1 & -.0000079835 & 0.00000362 & -2.21 & 0.1580\end{array}$

$\begin{array}{lllll}\mathrm{X} 4 & -.0203968593 & 0.00124779 & -16.35 & 0.0037\end{array}$

$\begin{array}{lllll}\mathrm{X} 5 & 0.0138803602 & 0.00029531 & 47.00 & 0.0005\end{array}$

$\begin{array}{llllll}\mathrm{X} 8 & -.0010964726 & 0.00003252 & -33.72 & 0.0009\end{array}$

$\begin{array}{lllll}\mathrm{X} 14 & -.0000691828 & 0.00002600 & -2.66 & 0.1170\end{array}$

Test1 analysis 23:27 Sunday, June 11, 20061

The GLM Procedure

$\begin{array}{ll}\text { Number of Observations Read } & 8 \\ \text { Number of Observations Used } & 8\end{array}$

Test1 analysis 23:27 Sunday, June 11, 20062

The GLM Procedure

Dependent Variable: Y2

\begin{tabular}{lrrrrr} 
& \multicolumn{2}{c}{ Sum of } & & & \\
Source & DF & Squares & Mean Square & F Value & Pr $>$ F \\
Model & 5 & 0.04412042 & 0.00882408 & 25.67 & 0.0379
\end{tabular}


Error

Corrected Total
$2 \quad 0.00068745 \quad 0.00034373$

$$
7 \quad 0.04480787
$$

$\begin{array}{lcrccc}\text { Source } & \text { DF } & \text { Type I SS } & \text { Mean Square } & \text { F Value } & \text { Pr }>\text { F } \\ & & & & & \\ \text { X1 } & 1 & 0.00010031 & 0.00010031 & 0.29 & 0.6432 \\ \text { X2 } & 1 & 0.03747343 & 0.03747343 & 109.02 & 0.0090 \\ \text { X5 } & 1 & 0.00518655 & 0.00518655 & 15.09 & 0.0603 \\ \text { X8 } & 1 & 0.00061435 & 0.00061435 & 1.79 & 0.3130 \\ \text { X14 } & 1 & 0.00074578 & 0.00074578 & 2.17 & 0.2786\end{array}$

$\begin{array}{lccccc}\text { Source } & \text { DF } & \text { Type III SS } & \text { Mean Square } & \text { F Value } & \text { Pr }>\text { F } \\ & & & & & \\ \text { X1 } & 1 & 0.00044415 & 0.00044415 & 1.29 & 0.3735 \\ \text { X2 } & 1 & 0.01932905 & 0.01932905 & 56.23 & 0.0173 \\ \text { X5 } & 1 & 0.00623221 & 0.00623221 & 18.13 & 0.0510 \\ \text { X8 } & 1 & 0.00077899 & 0.00077899 & 2.27 & 0.2712 \\ \text { X14 } & 1 & 0.00074578 & 0.00074578 & 2.17 & 0.2786\end{array}$

Standard

$\begin{array}{lrrrr}\text { Parameter } & \text { Estimate } & \text { Error } & \mathrm{t} \text { Value } & \operatorname{Pr}>|\mathrm{t}| \\ & & & & \\ \text { Intercept } & 2.033926387 & 0.94198485 & 2.16 & 0.1635 \\ \mathrm{X} 1 & 0.000125755 & 0.00011063 & 1.14 & 0.3735 \\ \mathrm{X} 2 & 5.120755409 & 0.68286543 & 7.50 & 0.0173 \\ \mathrm{X} 5 & -0.040307116 & 0.00946601 & -4.26 & 0.0510 \\ \mathrm{X} 8 & 0.001789106 & 0.00118844 & 1.51 & 0.2712\end{array}$




\section{$\begin{array}{lllll}\text { X14 } & -0.001163939 & 0.00079019 & -1.47 & 0.2786\end{array}$ \\ The GLM Procedure}

$\begin{array}{ll}\text { Number of Observations Read } & 8 \\ \text { Number of Observations Used } & 8\end{array}$

Test1 analysis 23:27 Sunday, June 11, 20066

The GLM Procedure

Dependent Va riable: Y3

Sum of

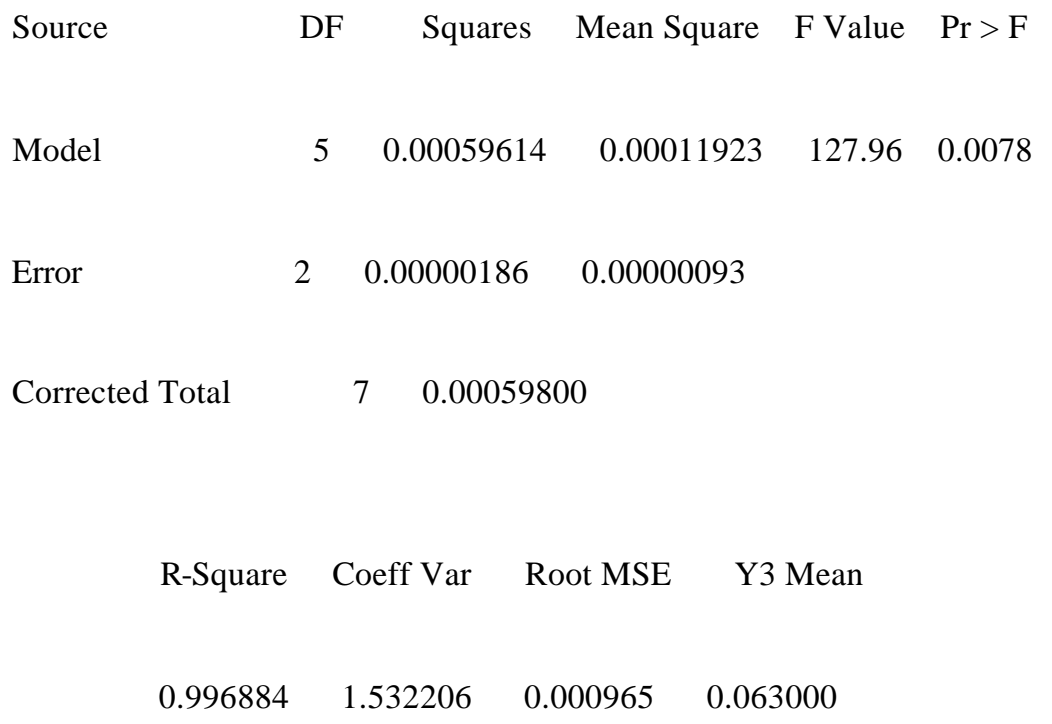

$\begin{array}{lcrccc}\text { Source } & \text { DF } & \text { Type I SS } & \text { Mean Square } & \text { F Value } & \text { Pr }>\text { F } \\ & & & & & \\ \text { X1 } & 1 & 0.00007086 & 0.00007086 & 76.05 & 0.0129 \\ \text { X2 } & 1 & 0.00029585 & 0.00029585 & 317.51 & 0.0031 \\ \text { X5 } & 1 & 0.00022040 & 0.00022040 & 236.54 & 0.0042 \\ \text { X8 } & 1 & 0.00000210 & 0.00000210 & 2.25 & 0.2721 \\ \text { X14 } & 1 & 0.00000692 & 0.00000692 & 7.42 & 0.1124\end{array}$




$\begin{array}{lccccc}\text { Source } & \text { DF } & \text { Type III SS } & \text { Mean Square } & \text { F Value } & \text { Pr }>\text { F } \\ & & & & & \\ \text { X1 } & 1 & 0.00001508 & 0.00001508 & 16.18 & 0.0566 \\ \text { X2 } & 1 & 0.00001658 & 0.00001658 & 17.80 & 0.0519 \\ \text { X5 } & 1 & 0.00019763 & 0.00019763 & 212.10 & 0.0047 \\ \text { X8 } & 1 & 0.00000125 & 0.00000125 & 1.35 & 0.3657 \\ \text { X14 } & 1 & 0.00000692 & 0.00000692 & 7.42 & 0.1124\end{array}$

\begin{tabular}{lrrrrr}
\multicolumn{2}{c}{ Standard } & & \\
Parameter & Estimate & Error & $\mathrm{t}$ Value & $\operatorname{Pr}>|\mathrm{t}|$ \\
& & & & & \\
Intercept & -.6154553332 & 0.04904506 & -12.55 & 0.0063 \\
$\mathrm{X} 1$ & 0.0000231724 & 0.00000576 & 4.02 & 0.0566 \\
$\mathrm{X} 2$ & 0.1499857509 & 0.03555384 & 4.22 & 0.0519 \\
$\mathrm{X} 5$ & 0.0071777200 & 0.00049285 & 14.56 & 0.0047 \\
$\mathrm{X} 8$ & -.0000718036 & 0.00006188 & -1.16 & 0.3657 \\
$\mathrm{X} 14$ & -.0001120976 & 0.00004114 & -2.72 & 0.1124
\end{tabular}

The GLM Procedure

$\begin{array}{ll}\text { Number of Observations Read } & 8 \\ \text { Number of Observations Used } & 8\end{array}$

Test1 analysis 23:27 Sunday, June 11, 200618

The GLM Procedure

Dependent Variable: Y4

Sum of

$\begin{array}{lrrrrr}\text { Source } & \text { DF } & \text { Squares } & \text { Mean Square } & \text { F Value } & \text { Pr }>\text { F } \\ \text { Model } & 5 & 0.00081094 & 0.00016219 & 2.34 & 0.3259 \\ & & & & & \\ \text { Error } & 2 & 0.00013856 & 0.00006928 & & \end{array}$


$\begin{array}{lll}\text { Corrected Total } & 7 & 0.00094950\end{array}$

$\begin{array}{llll}\text { R-Square } & \text { Coeff Var } & \text { Root MSE } & \text { Y4 Mean } \\ 0.854757 & 7.833838 & 0.008323 & 0.106250\end{array}$

$\begin{array}{lccccc}\text { Source } & \text { DF } & \text { Type I SS } & \text { Mean Square } & \text { F Value } & \text { Pr }>\text { F } \\ & & & & & \\ \text { X1 } & 1 & 0.00026951 & 0.00026951 & 3.89 & 0.1873 \\ \text { X11 } & 1 & 0.00009157 & 0.00009157 & 1.32 & 0.3692 \\ \text { X5 } & 1 & 0.00036803 & 0.00036803 & 5.31 & 0.1477 \\ \text { X8 } & 1 & 0.00008098 & 0.00008098 & 1.17 & 0.3927 \\ \text { X14 } & 1 & 0.00000085 & 0.00000085 & 0.01 & 0.9218\end{array}$

$\begin{array}{lccccc}\text { Source } & \text { DF } & \text { Type III SS } & \text { Mean Square } & \text { F Value } & \text { Pr }>\text { F } \\ & & & & & \\ \text { X1 } & 1 & 0.00007942 & 0.00007942 & 1.15 & 0.3964 \\ \text { X11 } & 1 & 0.00000101 & 0.00000101 & 0.01 & 0.9148 \\ \text { X5 } & 1 & 0.00044238 & 0.00044238 & 6.39 & 0.1274 \\ \text { X8 } & 1 & 0.00008180 & 0.00008180 & 1.18 & 0.3907 \\ \text { X14 } & 1 & 0.00000085 & 0.00000085 & 0.01 & 0.9218\end{array}$

\begin{tabular}{|c|c|c|c|c|}
\hline \multicolumn{5}{|c|}{ Standard } \\
\hline Paramete & Estimate & Error $\mathrm{t} \mathrm{V}$ & lue $\operatorname{Pr}$ & $>|t|$ \\
\hline Intercept & -.8434674946 & 0.42290335 & -1.99 & 0.1843 \\
\hline $\mathrm{X} 1$ & -.0000531768 & 0.00004967 & -1.07 & 0.3964 \\
\hline $\mathrm{X} 11$ & 0.0370595655 & 0.30657189 & 0.12 & 0.9148 \\
\hline $\mathrm{X} 5$ & 0.0107388956 & 0.00424976 & 2.53 & 0.1274 \\
\hline $\mathrm{X} 8$ & -.0005797707 & 0.00053355 & -1.09 & 0.3907 \\
\hline X14 & 0.0000393751 & 0.00035476 & 0.11 & 0.9218 \\
\hline
\end{tabular}


Test1 analysis 23:27 Sunday, June 11, 200625

The GLM Procedure

$\begin{array}{ll}\text { Number of Observations Read } & 8 \\ \text { Number of Observations Used } & 8\end{array}$

Test1 analysis 23:27 Sunday, June 11, 200626

The GLM Procedure

Dependent Variable: Y5

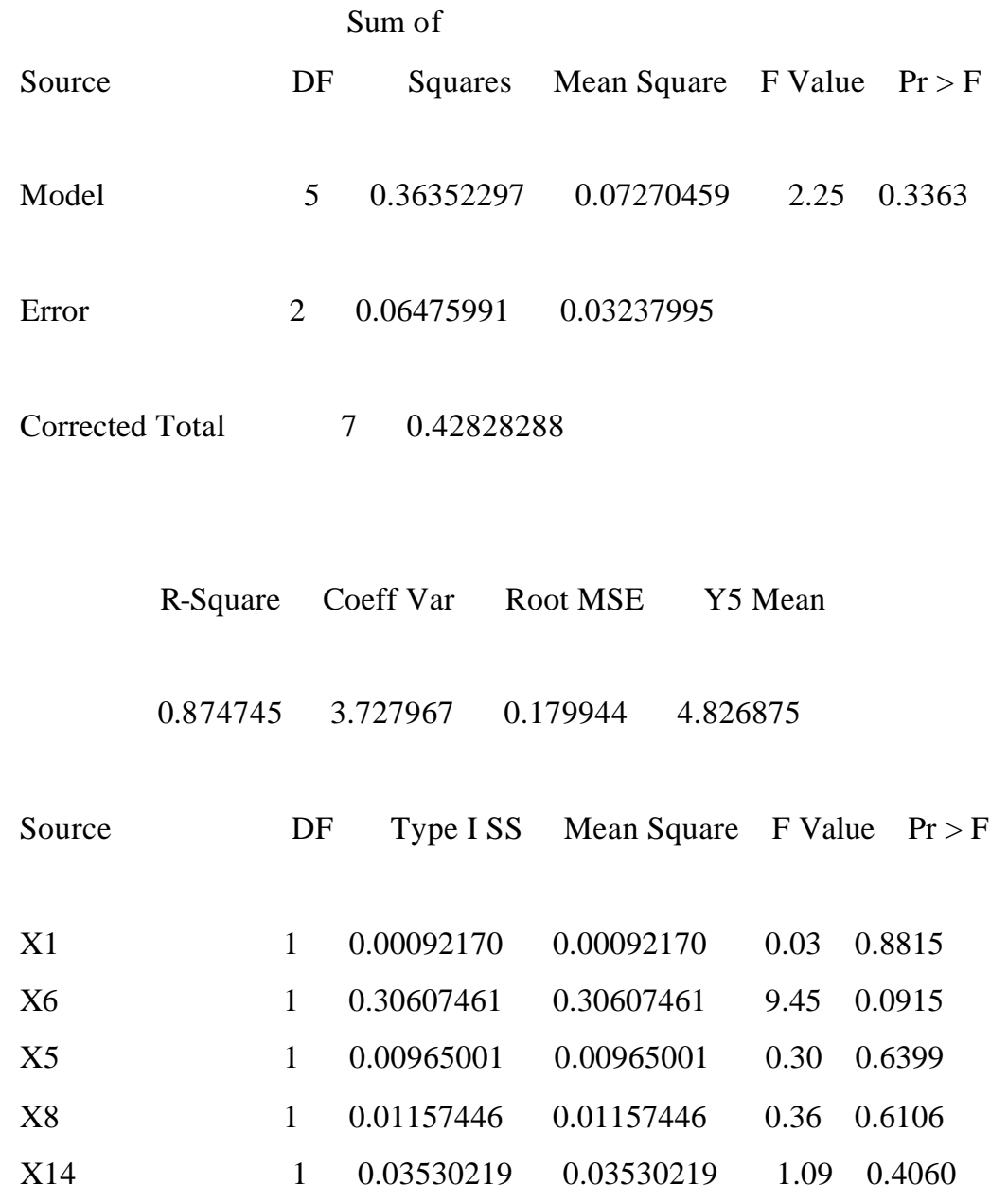




$\begin{array}{lccccc}\text { Source } & \text { DF } & \text { Type III SS } & \text { Mean Square } & \text { F Value } & \text { Pr }>\text { F } \\ & & & & & \\ \text { X1 } & 1 & 0.05775478 & 0.05775478 & 1.78 & 0.3134 \\ \text { X6 } & 1 & 0.13841507 & 0.13841507 & 4.27 & 0.1746 \\ \text { X5 } & 1 & 0.00113191 & 0.00113191 & 0.03 & 0.8689 \\ \text { X8 } & 1 & 0.01678144 & 0.01678144 & 0.52 & 0.5463 \\ \text { X14 } & 1 & 0.03530219 & 0.03530219 & 1.09 & 0.4060\end{array}$

\begin{tabular}{lrrrrr}
\multicolumn{7}{c}{ Standard } \\
Parameter & Estimate & Error & $\mathrm{t}$ Value & $\operatorname{Pr}>|\mathrm{t}|$ \\
& & & & & \\
Intercept & -10.51551490 & 9.14272646 & -1.15 & 0.3690 \\
X1 & 0.00143402 & 0.00107374 & 1.34 & 0.3134 \\
X6 & 13.70315324 & 6.62776249 & 2.07 & 0.1746 \\
X5 & -0.01717778 & 0.09187533 & -0.19 & 0.8689 \\
X8 & -0.00830396 & 0.01153477 & -0.72 & 0.5463 \\
X14 & 0.00800804 & 0.00766944 & 1.04 & 0.4060
\end{tabular}

Test1 analysis 23:27 Sunday, June 11, 200633

The GLM Procedure

$\begin{array}{ll}\text { Number of Observations Read } & 8 \\ \text { Number of Observations Used } & 8\end{array}$

Test1 analysis 23:27 Sunday, June 11, 200634

The GLM Procedure

Dependent Variable: Y6

Sum of

$\begin{array}{lrrrrr}\text { Source } & \text { DF } & \text { Squares } & \text { Mean Square } & \text { F Value } & \operatorname{Pr}>\text { F } \\ \text { Model } & 5 & 0.00263552 & 0.00052710 & 2.85 & 0.2802 \\ & & & & & \\ \text { Error } & 2 & 0.00037036 & 0.00018518 & & \end{array}$


$\begin{array}{lll}\text { Corrected Total } & 7 & 0.00300588\end{array}$

$\begin{array}{llll}\text { R-Square } & \text { Coeff Var } & \text { Root MSE } & \text { Y6 Mean } \\ 0.877465 & 6.231500 & 0.013608 & 0.218375\end{array}$

$\begin{array}{lcrccc}\text { Source } & \text { DF } & \text { Type I SS } & \text { Mean Square } & \text { F Value } & \text { Pr }>\text { F } \\ & & & & & \\ \text { X1 } & 1 & 0.00002871 & 0.00002871 & 0.16 & 0.7318 \\ \text { X4 } & 1 & 0.00048528 & 0.00048528 & 2.62 & 0.2469 \\ \text { X5 } & 1 & 0.00194233 & 0.00194233 & 10.49 & 0.0836 \\ \text { X8 } & 1 & 0.00017917 & 0.00017917 & 0.97 & 0.4290 \\ \text { X14 } & 1 & 0.00000002 & 0.00000002 & 0.00 & 0.9935\end{array}$

$\begin{array}{lccccc}\text { Source } & \text { DF } & \text { Type III SS } & \text { Mean Square } & \text { F Value } & \text { Pr }>\text { F } \\ & & & & & \\ \text { X1 } & 1 & 0.00001359 & 0.00001359 & 0.07 & 0.8119 \\ \text { X4 } & 1 & 0.00000190 & 0.00000190 & 0.01 & 0.9285 \\ \text { X5 } & 1 & 0.00208717 & 0.00208717 & 11.27 & 0.0784 \\ \text { X8 } & 1 & 0.00017695 & 0.00017695 & 0.96 & 0.4314 \\ \text { X14 } & 1 & 0.00000002 & 0.00000002 & 0.00 & 0.9935\end{array}$

\begin{tabular}{|c|c|c|c|c|}
\hline \multicolumn{5}{|c|}{ Standard } \\
\hline Paramete & Estimate & Error $\mathrm{t} \mathrm{V}$ & alue $\operatorname{Pr}$ & $>|t|$ \\
\hline Intercept & -1.723709296 & 0.69140594 & -2.49 & 0.1302 \\
\hline $\mathrm{X} 1$ & -0.000021996 & 0.00008120 & -0.27 & 0.8119 \\
\hline $\mathrm{X} 4$ & -0.050809363 & 0.50121529 & -0.10 & 0.9285 \\
\hline $\mathrm{X} 5$ & 0.023325969 & 0.00694794 & 3.36 & 0.0784 \\
\hline $\mathrm{X} 8$ & -0.000852703 & 0.00087230 & -0.98 & 0.4314 \\
\hline X14 & 0.000005362 & 0.00057999 & 0.01 & 0.9935 \\
\hline
\end{tabular}

